\title{
Manganese Deposits of Africa
}

\author{
Nicolas J Beukes ${ }^{1}$, Edward P.W. Swindell ${ }^{2}$ and Herve Wabo ${ }^{1}$ \\ ${ }^{1}$ PPM and CIMERA, Department of Geology, University of Johannesburg, Auckland Park 2006, South Africa. \\ E-mail:nbeukes@uj.ac.za; waboherve@yahoo.fr \\ ${ }^{2}$ Ed Swindell Consulting Geologist, 68 Cuckoo's Nest Road, Featherbrooke Estate, Krugersdorp 1739, South Africa. \\ E-mail: edswindell@telkomsa.net
}

DOI: $10.18814 /$ epiiugs/2016/v39i2/95779

Africa hosts just over 80 percent (\%) of the world's known land-based ore resources of manganese metal and produced some $41.1 \%$ of the 18 million tonnes (Mt) of manganese metal in ores, that was mined during 2014. The deposits are mainly of sedimentary and supergene origin comprising four major types, namely banded iron formation (BIF)-hosted, black shale-hosted, oolitic and supergene/karst-hosted deposits. The BIF-hosted Kalahari Manganese Field (KMF) is by far the largest of these deposits holding some 4,200 Mt of manganese metal that represents about $77 \%$ of the world's known land-based resource. Other major deposits are present in the Francevillian of Gabon, represented by high-grade supergene manganese oxide ores derived from weathering of rhodochrosite-bearing black shale source rock, and manganese carbonates interbedded with black shale and greywackes associated with volcanicdominated orogenic belts in the Birimian of West Africa and Lukoshi Complex at Kisenge in the Democratic Republic of the Congo (DRC). High-grade supergene manganese oxide ores cap the manganese carbonate beds. All these major ore deposits formed in the interval 2.0-2.2 Ga. Additional deposits that contain only relatively small resources but that hold important scientific information about the Earth's history include the 2.4 Ga BIF-hosted Rooinekke deposit of the Transvaal Supergroup, which formed prior to the 2.32 Ga Great Oxidation Event (GOE), karst-hosted deposits of the Postmasburg area that formed along a 2.0 Ga palaeoweathering profile below red beds of the Gamagara/Mapedi succession in South Africa, the $\sim 1.9$ Ga Tolwe deposit that represents the oldest known example of oolitic manganese ore in the world and the BIF-hosted Otjosondu deposit in Namibia, related to the Neoproterozoic Sturtian Snowball Earth Event (an extremely cold period of time in geologic history when Earth was covered by a virtual global ice cap).
The manganese carbonates present in most of these deposits are all highly enriched in light organic carbon isotopes indicating that they were derived from reduction of original manganese oxide precipitates by organic carbon during diagenesis. This implies that the water columns from which the sedimentary manganese beds originally precipitated, as well as the floors of the depositories, were oxygenated. Post Archaean Australian Shale (PAAS)-normalized cerium (Ce) anomalies in Rare Earth Element (REE) data, support the presence of oxic conditions in the basins. It is thus not surprising that all the major 2.0-2.2 Ga deposits formed after the GOE. In this regard the relatively small BIF-hosted Rooinekke manganese deposit is very significant in that it formed prior to the GOE suggesting that at least some free oxygen was present in ocean basins before that time. There also appears to have been a major tectonosedimentary control on the distribution of the major 2.0$2.2 \mathrm{Ga}$ deposits. All of them, including the KMF, apparently formed in back-arc basinal settings immediately prior to amalgamation of cratonic blocks along Eburnian orogenic belts and formation of the supercontinent Columbia.

\section{Introduction}

Africa hosts a large number of mainly sedimentary manganese ore deposits and occurrences with a few minor hydrothermal ones (Fig. 1). The sedimentary deposits comprise four major types, namely banded iron formation-hosted (BIF-hosted), black shale-hosted, karsthosted and oolitic deposits (Fig. 1). The BIF-hosted deposits include the giant $\sim 2.2 \mathrm{Ga}$ Kalahari Manganese Field of South Africa and small 2.4 Ga Rooinekke and Cryogenic ( 0.74 Ga) Otjosondu deposits of South Africa and Namibia respectively (Figs. 1 and 2). Large black shale-hosted deposits are represented by those of the Francevillian succession in Gabon, the Birimian succession of West Africa and the Kisenge district of the DRC (Fig. 1). They typically consist of Cenozoic supergene manganese oxide ores capping 2.02.2 Ga manganese carbonate-bearing black shale protores (Fig. 2). Significant karst-hosted deposits are represented by the $\sim 2.0 \mathrm{Ga}$ Postmasburg Manganese Field in South Africa and the Cretaceous 


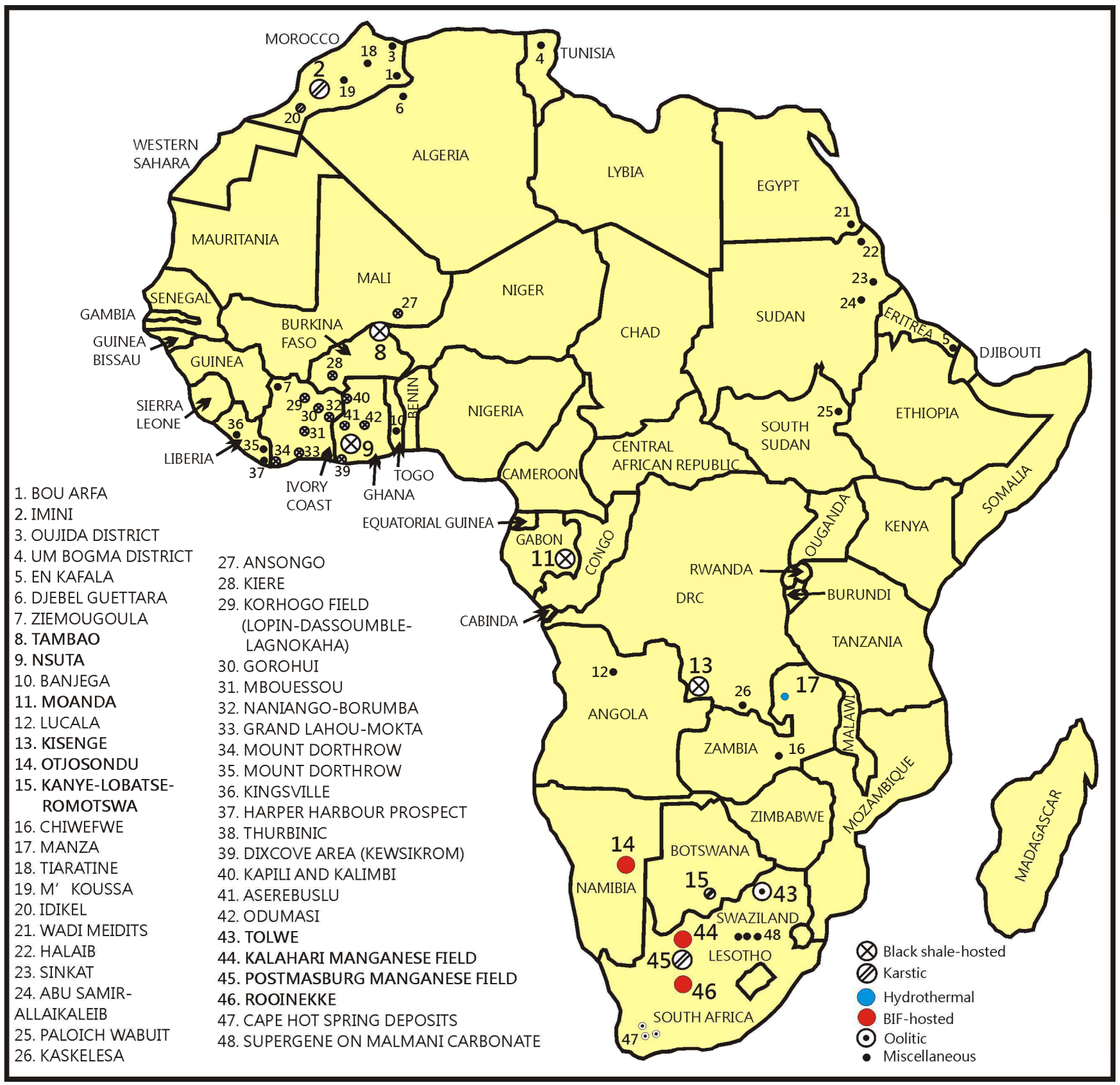

Fig. 1. Map of Africa indicating location and classification of manganese ore deposits and occurrences.

Imini district in Morocco (Figs. 1 and 2). The $~ 1.9$ Ga Tolwe manganese deposit in South Africa (Figs. 1 and 2) is the only oolitic deposit from which some minor production has come in the past. It is the purpose of this paper to review the geological setting and ore characteristics of these deposits in terms of understanding the varied origin of sedimentary manganese deposits and controls on their temporal distribution in Earth's history.

It is important to realize that currently, virtually all of the production of manganese ore in Africa comes from only two of the deposit types, mined in three districts, namely BIF-hosted deposits of the Kalahari Manganese Field (KMF) in South Africa and black shale-hosted deposits of the Francevillian district in Gabon and the Birimian district of West Africa (Fig. 1). This paper will focus on reviewing information available on these deposits with shorter descriptions of the others. Another reason for focusing on these deposits lies in their major contribution to the world's known landbased manganese resource and the current production of manganese metal. Two of these districts, namely the Kalahari Manganese Field in South Africa and the Francevillian succession in Gabon, host some $80 \%$ of the worlds known land-based manganese metal resource, which is estimated to be in the order of 5,200 Mt. By far the largest component of this resource, namely $77 \%(\sim 4,200 \mathrm{Mt})$, occurs in the giant Kalahari Manganese Field in South Africa, with 3\% present in Gabon (Fig. 3a). Smaller but important resources, in combination amounting to less than $1 \%$ of the total world resource (Fig. 3a), and from which production comes at present, are located in the Birimian succession of West Africa in Ghana (essentially the Nsuta Mine), Burkina Faso and Cote d'Ivoire (Fig. 1). However, of this total ore resource only some $11 \%$ (570 Mt manganese metal) is considered proven reserves (Fig. 3b). This large discrepancy mainly relates to 


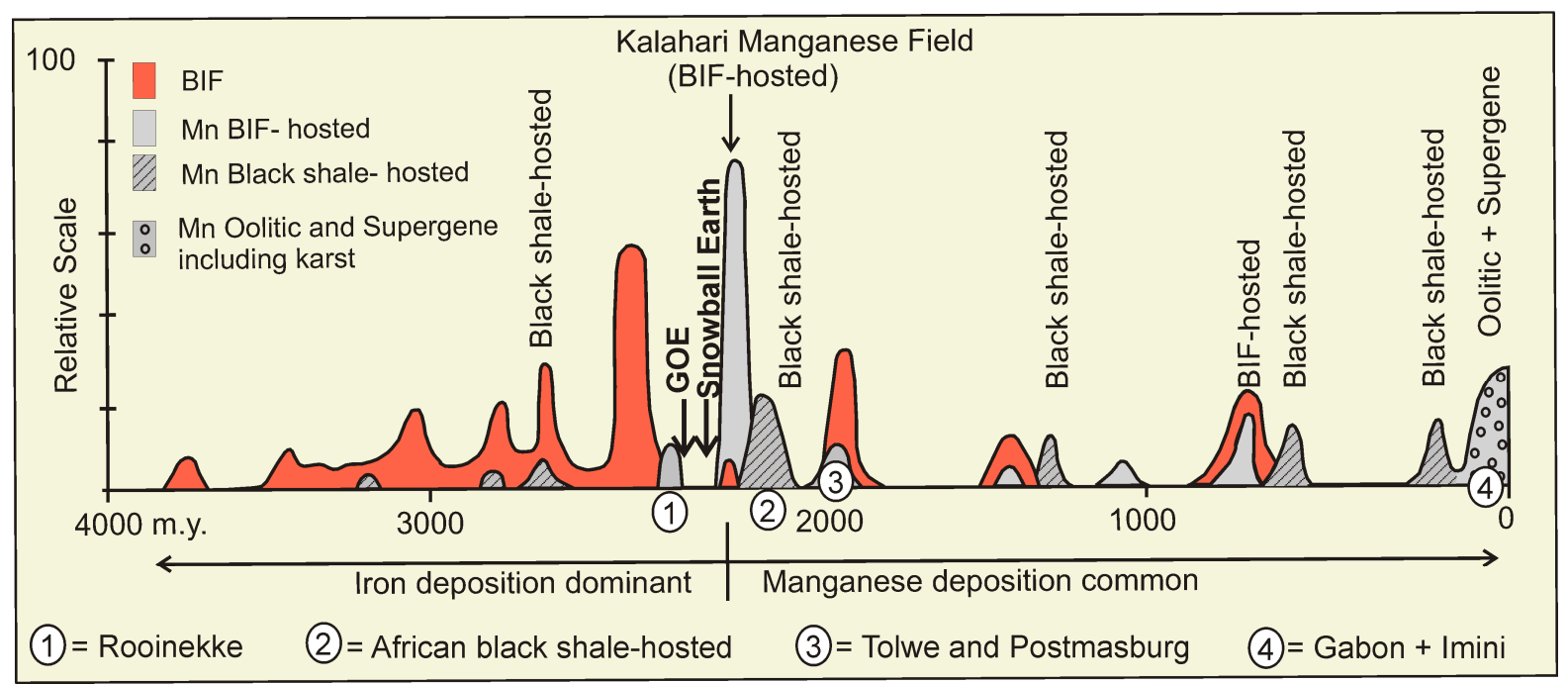

Fig. 2. Schematic indication of temporal distribution of major manganese deposits compared to that of iron formation (Modified after Cairncross and Beukes, 2013).

the Kalahari Manganese Field in which only 150 Mt of manganese metal $(\sim 3.6 \%$ of the total estimated world resource) is considered proven economic ore reserve by the U.S. Geological Survey Mineral Commodity Summary (January 2015). This represents $26.3 \%$ of the 2014 proven world manganese metal ore reserve (Fig. 2b). An additional $24 \mathrm{Mt}$ is present in Gabon, which implies that Africa hosts at least $30.5 \%$ of the world's total land-based proven manganese metal ore reserve (Fig. 3b). With these large ore reserves and resources it is thus not surprising that Africa is a major supplier of manganese ore in the world, producing at least 41.1 percent of the $18 \mathrm{Mt}$ of manganese metal mined during 2014. Overall, South Africa was the biggest supplier at $26.1 \%$ followed by China (17.8\%), Australia (17.2\%) and Gabon (11.1\%). Ghana contributed a further $3 \%$ from the Nsuta Mine with all other African producing countries contributing in total less than $3.6 \%$ of all manganese metal contained in ores mined in the world during 2014 (Fig. 3c). Most of Africa's manganese production is exported as manganese ore with the little downstream enrichment mainly confined to South Africa, Zambia and Gabon (Corathers, 2014). Due to the large number of manganese minerals occurring in deposits the reader should refer to the glossary at the end of the paper for chemical compositions of the minerals.

\section{BIF-hosted Deposits}

\section{Kalahari Manganese Field, South Africa}

The Kalahari Manganese Field (KMF) is hosted by the circa 2.2 Ga Hotazel Iron Formation of the Postmasburg Group of the Transvaal Supergroup in the Griqualand West area of the Northern Cape Province of South Africa (Figs. 1 and 4; Table 1). It is linked by rail to export harbors at Port Elizabeth (on the south coast) and Saldanha Bay (on the west coast), and inland manganese ferroalloy plants at Meyerton, Machadodorp and Cato Ridge. These plants produce some 880,000 tonnes of manganese ferroalloy per annum which represented some 5\% of the world's production in 2012 (Corathers, 2014).

The KMF is, for the most part, covered by Cretaceous-Cenozoic gravel, clay, calcrete and sand of the Kalahari Formation. Only one natural outcrop of the Hotazel Formation, with interbedded manganese ore, exists in a small hill known as Black Rock (Fig. 4). It was described for the first time by Rogers (1907) but, because of its remote location and the absence of surface water on the sandy plains of the Kalahari, it was not until the Second World War, with shortages of manganese supply developing from the Postmasburg Manganese Field on the Maremane dome further to the south (Fig. 4a), that it was again visited by Guido Sacco, a young Italian geologist. He immediately realized the potential of the manganese beds in the Hotazel iron formation and opened the Black Rock Mine in 1940 (Cairncross and Beukes, 2013). This, in turn, resulted in much exploration interest in the area and soon the large extent of the manganese field became apparent, mainly through mapping by Boardman (1941) and ground magnetic surveys in the late 1940s to early 1950s (De Villiers, 1960; 1970). This led to the opening of two new open pit mines along the sub-outcrop of the Hotazel Formation below Kalahari sand on the farms Devon and Smartt. One of the most significant early developments in the manganese field was the discovery of very high-grade deposits in an outlier of the Hotazel Formation, in a graben immediately east of the Main Kalahari deposit (Fig. 4). This discovery provided the economic basis for extending the railway line northwards from Postmasburg and Sishen, to Hotazel during 1961 and was followed by major expansion in further exploration and mining, essentially by two companies, Assmang and Samancor (Cairncross et al., 1997). They each operated two large mines at the turn of the last century namely N'Chwaning and Gloria (Assmang) and Wessels and Mamatwan (Samancor/BHP-Billiton) (Fig. 6). This situation changed during 2004 with transfer of ownership of the mineral rights in South Africa from private- to governmentownership. This led to the allocation of exploration and mining licenses to several additional companies that, in turn, led to the opening of five new mines in the past six years in the KMF (Fig. 6) and to South Africa becoming the largest producer of manganese in the world since 2010 (Cairncross and Beukes, 2013).

The geology of the KMF, and especially the composition of the Hotazel iron formation and associated manganese ore beds, have been the subject of a large number of scientific studies and publications in the past three decades. However, the KMF is not only known for its giant resource of manganese ore, but also for producing a spectacular array of collectors mineral specimens and very rare to type-locality 


\section{a Total land-based resources} (approximately 5200 million tons of $\mathrm{Mn}$ metal)

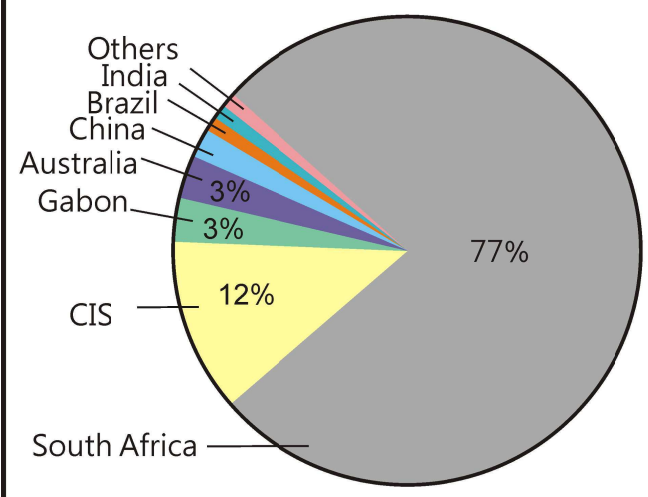

\section{b Proven reserves}

(total 570 million tons of $\mathrm{Mn}$ metal of countries in which proven reserves are known)

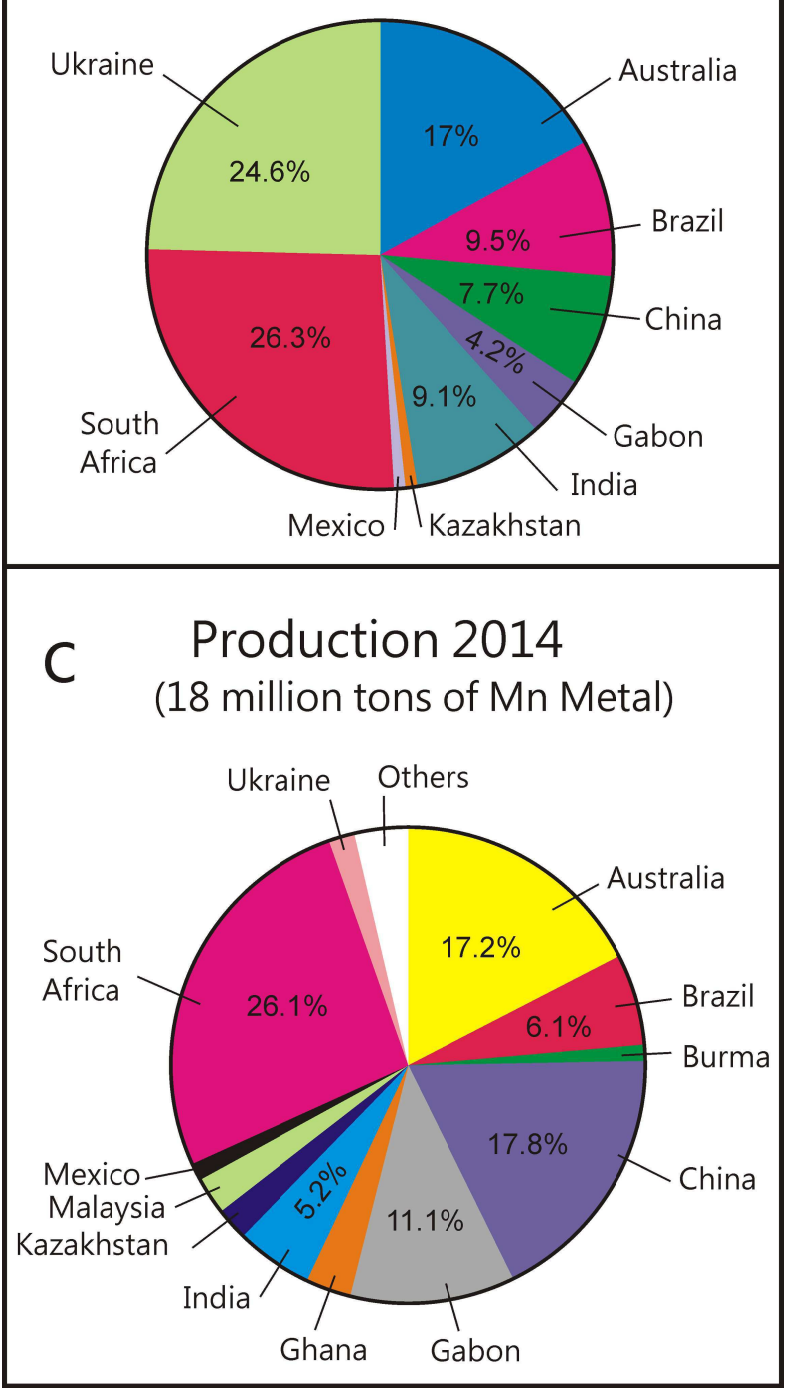

Fig. 3. (a) World's land-based manganese metal resources. (b) proven reserves and (c) production. ( $a$ and $b$ modified from Cairncross and Beukes (2013)) and c from U.S. Geological Survey, Mineral Commodity Summaries, January 2015. mineral species. The reader is referred to Cairncross and Beukes (2013) for a complete reference list to the geological and mineralogical studies on the KMF. For the sake of brevity it should be noted that the following description of the KMF is based on publications most relevant to the geological setting and composition of ore beds in the KMF that include Kleyenstüber (1984), Nel et al. (1986), Beukes et al.(1995), Gutzmer and Beukes (1995; 1996a; 1997), Cairncross et al. (1997), Tsikos and Moore (1997;1998), Tsikos et al. (2001; 2003), Schneiderhan et al. (2006) and Chetty and Gutzmer (2008; 2012).

The KMF comprises five erosional relicts of the circa $2.2 \mathrm{Ga}$ Hotazel Formation composed of iron formation with three interbeds of sedimentary manganese ore along the axis of the Dimoten syncline, northwest of Kuruman. The erosional relicts are known as the Main Kalahari, Avontuur, Leinster, Langdon and Hotazel deposits (Fig. 4a). The three sedimentary manganese ore beds are interbedded with the iron formation and are known, from bottom to top, as the Lower, Middle and Upper Manganese beds (Fig. 4b). The Hotazel Formation gradationally overlies mafic pillow lava and hyaloclastite of the $\sim 2.22 \mathrm{Ga}$ Ongeluk Formation (Fig. 4) and is, in turn, conformably overlain by the Mooidraai Dolomite (Fig. 4b) (Kunzmann et al., 2014) that forms the topmost known preserved unit of the Transvaal Supergroup in the area. A major erosional unconformity occurs at the top of the Transvaal succession and this is overlain by $\sim 2.0 \mathrm{Ga}$ red beds of the Mapedi/Gamagara Formation of the Elim Group of the Kheis Supergroup (Fig. 4a and b).

A major low-angle thrust fault system, with estimated eastward displacement of 35-60 km (Beukes and Smit, 1987), is present along the western margin of the Kalahari deposit (Fig. 4a). In the hangingwall of the thrust, the manganese and iron formation beds of the Hotazel Formation, together with the overlying Mooidraai dolomite, appear to interfinger westward with a succession of granular jasper, tuffaceous shale, chert breccia, minor dolomite and mafic lava, known as the Beaumont Formation (Fig. 4b). It is clear that the Hotazel Formation originally had a much wider distribution than that currently preserved. This is not only indicated by preservation of the succession in erosional relicts to the far north of the Main Kalahari deposit but also in outcrops some $200 \mathrm{~km}$ south of Hotazel near Matsap, along the axis of the Ongeluk-Witwater syncline (Fig. 4a). However, here only jaspilitic iron formation from below the Lower Manganese ore bed of the Hotazel Formation appears to have been preserved.

Although in this review the age of the Ongeluk Lava and overlying Hotazel-Mooidraai succession is given to be in the order of 2.222.0 Ga (Cornell et al., 1996; Beukes et al., 2013), there is another school of thought that suggests the age to be much older, in the order of 2.4 Ga (Bau et al., 1999; Moore et al., 2012). This discrepancy has not been resolved and requires careful additional radiometric age dating, combined with regional geological correlation and mapping of strata.

Currently, all production in the KMF comes from the Main Kalahari deposit. The Hotazel and Langdon deposits, preserved in down-faulted blocks immediately west of the main deposit, have essentially been mined out. Ore beds in the Avontuur deposit (Fig. 4a) are intruded by a pre-Mapedi mafic sill and are generally deep, in excess of $200 \mathrm{~m}$ below surface, with ore suitable for open cast mining only being present in the northeastern corner of the deposit, below a cover of Kalahari sediments (Cairncross and Beukes, 2013). The Leinster deposit, situated some $100 \mathrm{~km}$ north of the Main Kalahari deposit (Fig. 4a), has little economic potential because of its low grade (12-20 wt\% manganese (Mn)) and Kalahari sediment cover of 


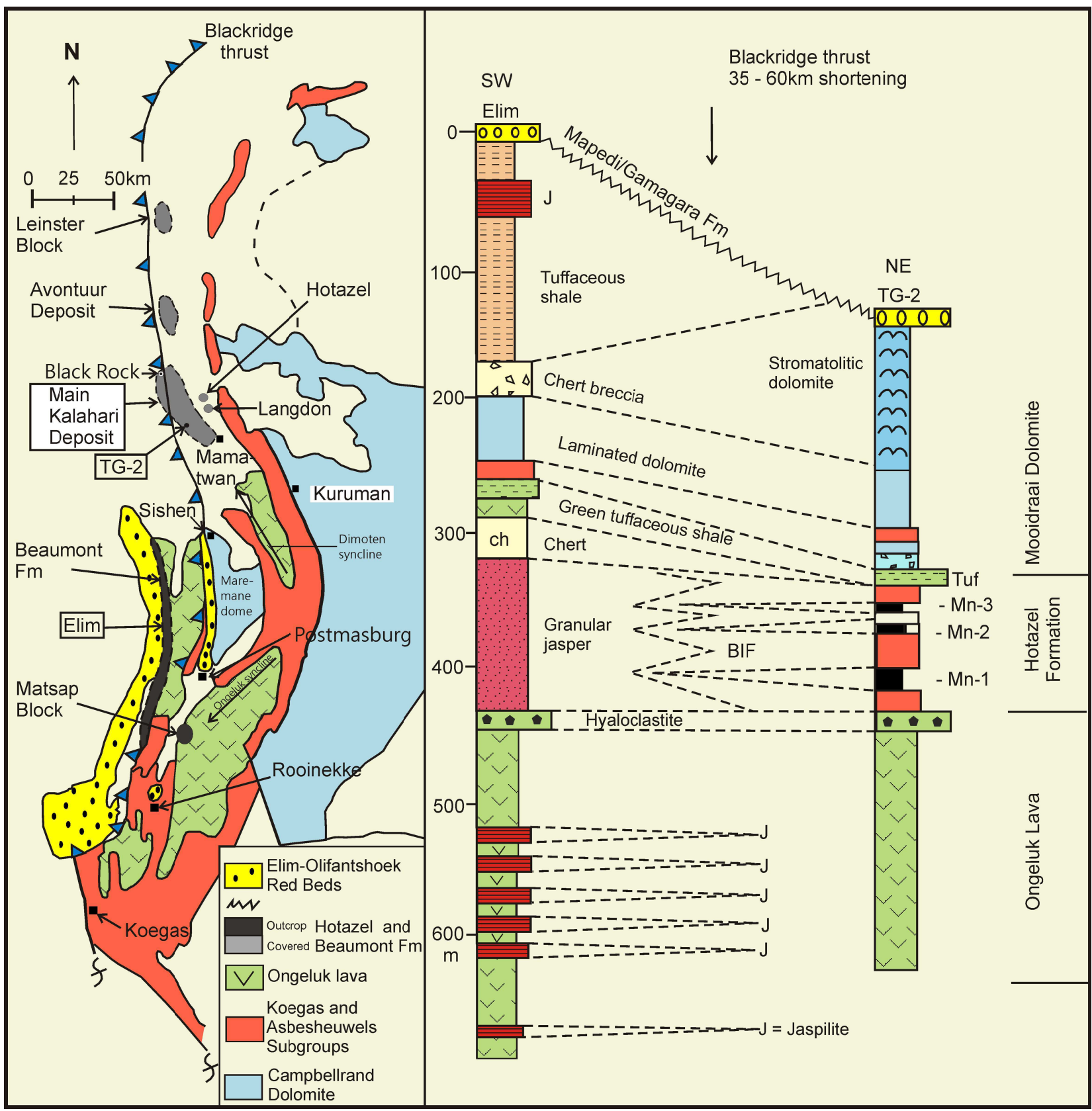

Fig. 4. (a) Regional map of the Transvaal Supergroup in Griqualand West showing the distribution of the Kalahari Manganese Field and Black Ridge thrust fault. (b) Schematic diagram indicating lateral interfingering of the Hotazel and Mooidraai formations of the KMF on the Kaapvaal Craton to the east, in the footwall of the Black Ridge thrust fault with the Beaumont Formation to the west off the craton in the hangingwall of the thrust (from Cairncross and Beukes, 2013).

at least 110-150 $\mathrm{m}$ in thickness (Swindell, 2015).

The structure of the Main Kalahari deposit is that of a double plunging syncline that was peneplaned by erosion prior to deposition of the overlying $~ 2.0 \mathrm{Ga}$ Mapedi/Gamagara red bed succession of the Elim Group (Fig. 5a and c). The syncline, together with the Mapedi/Gamagara red beds, were tilted to the northwest prior to, or during, development of the Black Ridge thrust fault that duplicates strata along the western margin of the synclinal structure (Fig. 5b). In Gondwana times, during the late Carboniferous, the succession was transected by deep north-south striking glacial valleys, followed by deposition of the basal glacial Dwyka diamictite of the Karoo Supergroup. Uplift in post-Gondwana times led to erosion of the Karoo succession and deposition of a veneer of Cretaceous-Cenozoic
Kalahari sediments (Fig. $5 \mathrm{~b}$ and c). The result of all of this is that the manganese beds are shallow and suitable for open-pit mining along the southeastern margin of the Main Kalahari deposit in the vicinity of Mamatwan Mine and become deeper (up to 1,400 m below surface), to the west and northwest, where the beds are mined underground at depths of up to $\sim 400 \mathrm{~m}$ in the Wessels and Nchwaning mines (Fig. 5c).

A simplified pre-Karoo structural map of the Main Kalahari deposit illustrates the presence of a major north-south striking post-Mapedi/Gamagara graben structure, known as the WesselsN'Chwaning graben, along the central axis of the deposit and the trace of the Black Ridge thrust fault to the west of that,with the original outcrop of the Hotazel Formation at Black Rock, located in the 
Table 1. Summary comparative table of significant manganese deposits in Africa

\begin{tabular}{|c|c|c|c|c|c|c|c|c|c|}
\hline Classification & BIF-hosted & BIF-hosted & BIF-hosted & $\begin{array}{l}\text { Black shale- } \\
\text { hosted }\end{array}$ & $\begin{array}{l}\text { Black shale- } \\
\text { hosted }\end{array}$ & $\begin{array}{l}\text { Black shale- } \\
\text { hosted }\end{array}$ & Karst-hosted & Karst-hosted & Oolitic \\
\hline Field/Deposit name & $\begin{array}{l}\text { KMF } \\
\text { South Africa }\end{array}$ & $\begin{array}{l}\text { Rooinekke } \\
\text { South Africa }\end{array}$ & $\begin{array}{l}\text { Otjosondu } \\
\text { Namibia }\end{array}$ & $\begin{array}{l}\text { Francevillian } \\
\text { Gabon }\end{array}$ & $\begin{array}{l}\text { Birimian } \\
\text { West Africa }\end{array}$ & $\begin{array}{l}\text { Kisenge } \\
\text { DRC }\end{array}$ & $\begin{array}{l}\text { Postmasburg } \\
\text { South Africa }\end{array}$ & $\begin{array}{l}\text { Imini } \\
\text { Morocco }\end{array}$ & $\begin{array}{l}\text { Tolwe } \\
\text { South Africa }\end{array}$ \\
\hline Host Formation & Hotazel BIF & $\begin{array}{l}\text { Rooinekke } \\
\text { BIF }\end{array}$ & Chuos BIF & $\begin{array}{l}\text { Bangombe } \\
\text { Formation }\end{array}$ & $\begin{array}{l}\text { Upper } \\
\text { Birimian }\end{array}$ & $\begin{array}{l}\text { Lukoshi } \\
\text { Complex }\end{array}$ & $\begin{array}{l}\text { Campbellrand } \\
\text { dolomite }\end{array}$ & $\begin{array}{l}\text { Mid Cretaceous } \\
\text { Dolostone }\end{array}$ & $\begin{array}{l}\text { Wyllies Poort } \\
\text { Formation }\end{array}$ \\
\hline Host Age & $\sim 2.2 \mathrm{Ga}$ & $\sim 2.4 \mathrm{Ga}$ & $\sim 0.74 \mathrm{Ga}$ & $2.0-2.3 \mathrm{Ga}$ & $2.2-2.16 \mathrm{Ga}$ & $2.1-2.2 \mathrm{Ga}$ & $2.5-2.6 \mathrm{Ga}$ & $0.085-0.097 \mathrm{Ga}$ & $1.8-1.96 \mathrm{Ga}$ \\
\hline $\begin{array}{l}\text { Primary/proto } \\
\text { sedimentary rock }\end{array}$ & $\begin{array}{l}\text { Braunite- } \\
\text { Kutnahorite } \\
\text { Lutite }\end{array}$ & $\begin{array}{l}\text { Cherty Mn } \\
\text { carbonate }\end{array}$ & $\begin{array}{l}\text { Braunite- } \\
\text { Jacobsite } \\
\text { Manganostone }\end{array}$ & $\begin{array}{l}\text { Manganocrete } \\
\text { capping } \\
\text { rhodochrositic } \\
\text { black shale }\end{array}$ & Mn-carbonate & Mn-carbonate & $\begin{array}{l}\text { Braunite and } \\
\text { Partridgeite } \\
\text { karst fill }\end{array}$ & $\begin{array}{l}\text { Pyrolusitic cave } \\
\text { fill }\end{array}$ & $\begin{array}{l}\text { Braunite } \\
\text { oolite and } \\
\text { oncolite }\end{array}$ \\
\hline $\begin{array}{l}\text { Hydrothermal/ } \\
\text { Metamorphic } \\
\text { Alteration }\end{array}$ & $\begin{array}{l}\text { Hausmannite } \\
\text { Bixbyite } \\
\text { Braunite II }\end{array}$ & $\begin{array}{l}\text { Braunite } \\
\text { Jacobsite } \\
\text { Rhodonite }\end{array}$ & $\begin{array}{l}\text { Mn-garnet and } \\
\text { clinopyroxene }\end{array}$ & None & $\begin{array}{l}\text { Mn-garnet } \\
\text { Rhodonite }\end{array}$ & Mn-garnet & Bixbyite & None & None \\
\hline Supergene ore & Tod, Mm, Pyr & $\mathrm{Mm}, \mathrm{Pyr}$ & Minor Mn (IV) & Cry, Li, Pyr, Ns & $\mathrm{Ps}, \mathrm{Cr}, \mathrm{Pyr}, \mathrm{Ns}$ & Cry, Pyr & Cr, Rom & None & Pyr, Cry \\
\hline $\begin{array}{l}\text { Timing supergene } \\
\text { alteration }\end{array}$ & $\begin{array}{l}\text { Pre-Mapedi } \\
2 \mathrm{Ga} \\
\text { Cenozoic: } \sim 42, \\
25,10.5 \mathrm{Ma}\end{array}$ & Cenozoic & Cenozoic & Cenozoic & $\begin{array}{l}\text { Tambao } \\
44.5-49 \mathrm{Ma}\end{array}$ & $\begin{array}{l}\sim 25,10,3.6 \text { and } \\
2.6 \mathrm{Ma}\end{array}$ & $\begin{array}{l}\text { Original karst } \\
\text { at } 2.0 \mathrm{Ga}\end{array}$ & $\begin{array}{l}\text { Karsting in } \\
\text { Senomanian }\end{array}$ & Cenozoic \\
\hline $\begin{array}{l}\text { Principal Economic } \\
\text { Ore Type }\end{array}$ & $\begin{array}{l}\text { Oxide and mixed } \\
\text { carbonate/oxide }\end{array}$ & $\begin{array}{l}\text { Ferruginous } \\
\text { oxide ore }\end{array}$ & Oxide ore & Oxide ore & $\begin{array}{l}\text { Oxides and } \\
\text { carbonate ores }\end{array}$ & Oxide ore & $\begin{array}{l}\text { Ferruginous and } \\
\text { siliceous ore }\end{array}$ & Oxide ore & Oxide ore \\
\hline Mn ore grades & $\begin{array}{l}\text { Mamatwan ores: } \\
30-38 \% \mathrm{Mn} \text {. } \\
\mathrm{Mn} / \mathrm{Fe} 8.5-10.1 \\
\text { Wessels ores } \\
46-55 \% \mathrm{Mn} \\
\mathrm{Mn} / \mathrm{Fe}-4: 1\end{array}$ & $\begin{array}{l}\text { Average } \\
35 \% \mathrm{Mn}, \\
25-27 \% \mathrm{Fe}\end{array}$ & $\begin{array}{l}\text { Average } 22 \% \\
\text { up to } 33-47 \% \mathrm{Mn} \\
\mathrm{Mn} / \mathrm{Fe}=2.2-14.8 \\
\text { High Ba. }\end{array}$ & $\begin{array}{l}\text { Protore - }<15 \% \\
\mathrm{Mn} \\
\text { Oxide Ore - } \\
40-48 \% \mathrm{Mn} \\
\mathrm{Mn} / \mathrm{Fe}= \\
2.17-15.0\end{array}$ & $\begin{array}{l}\text { Carbonate ore - } \\
28-30 \% \mathrm{Mn} \\
\text { Oxide ore - } \\
40-55 \% \mathrm{Mn} \\
\mathrm{Mn} / \mathrm{Fe}=30-37.47\end{array}$ & $\begin{array}{l}\text { Carbonate ore - } \\
28-30 \% \mathrm{Mn} \\
\mathrm{Mn} / \mathrm{Fe}=40-41 \\
\text { Oxide ore - } \\
40-55 \% \mathrm{Mn} \\
\mathrm{Mn} / \mathrm{Fe}=14-26\end{array}$ & $\begin{array}{l}\text { Ferruginous ore } \\
32-55 \% \mathrm{Mn} \\
\mathrm{Mn} / \mathrm{Fe}=1.5-21,8 \\
\text { Siliceous ores } \\
46-59 \% \mathrm{Mn} ; \\
\mathrm{Mn} / \mathrm{Fe}=7,1-65\end{array}$ & $\begin{array}{l}30-(+) 47 \% \mathrm{Mn} \\
\mathrm{Mn} / \mathrm{Fe}=20-330 \\
\mathrm{High} \mathrm{Pb} \& \mathrm{Ba}\end{array}$ & $\begin{array}{l}\text { Oxide ore } \\
30-41 \% \mathrm{Mn} \\
\mathrm{Mn} / \mathrm{Fe}=1.75-10\end{array}$ \\
\hline $\begin{array}{l}\text { Resource Potential } \\
\text { Ranges }\end{array}$ & $\begin{array}{l}12 \text { - } 15 \text { billion } \\
\text { tonnes @ 30- } \\
38 \% \mathrm{Mn}\end{array}$ & $\begin{array}{l}<1 \text { million } \\
\text { tonnes }\end{array}$ & $20-50 \mathrm{Mt}$ & $\begin{array}{l}\text { Oxide ore } \\
200-480 \mathrm{Mt}\end{array}$ & $\begin{array}{l}\text { Oxide ore }<20 \mathrm{Mt} \\
\text { per deposit } \\
\text { Carbonate ore } \\
\text { untested }\end{array}$ & $\begin{array}{l}\text { Oxide ore }<20 \mathrm{Mt} \\
\text { Carbonate ore } \\
\text { untested }\end{array}$ & $10-30 \mathrm{Mt}$ & $<10 \mathrm{Mt}$ & $10-15 \mathrm{Mt}$ \\
\hline Production & Major & Defunct & $\begin{array}{l}\text { Intermittent } \\
\text { minor }\end{array}$ & Major & $\begin{array}{l}\text { Nsuta minor } \\
\text { Others intermittent } \\
\text { minors }\end{array}$ & $\begin{array}{l}\text { Past minor } \\
\text { producer }\end{array}$ & Minor producer & Minor producer & Defunct \\
\hline $\begin{array}{l}\text { Tectono- } \\
\text { stratigraphic } \\
\text { setting }\end{array}$ & $\begin{array}{l}\text { Retroarc basin, } \\
\text { Kaapvaal craton } \\
\text { margin }\end{array}$ & $\begin{array}{l}\text { Trailing margin } \\
\text { basin, Kaapvaal } \\
\text { Craton }\end{array}$ & $\begin{array}{l}\text { Trailing margin } \\
\text { basin? }\end{array}$ & $\begin{array}{l}\text { Platform basin } \\
\text { adjacent to } \\
\text { retroarc basin? } \\
\text { on Congo Craton }\end{array}$ & $\begin{array}{l}\text { Mafic and felsic- } \\
\text { dominated back } \\
\text { arc basins }\end{array}$ & Back arc basin? & $\begin{array}{l}\text { Uplifted carbonate } \\
\text { platform }\end{array}$ & $\begin{array}{l}\text { Uplifted } \\
\text { carbonate } \\
\text { platform }\end{array}$ & $\begin{array}{l}\text { Platform } \\
\text { Fluvio deltaic }\end{array}$ \\
\hline
\end{tabular}

Mineralogy abbreviations - Brn-Braunite, Bx - Bixbyite, Cry - Cryptomelane, H - Hausmannite, Ho - Hollandite, Jb - Jacobsite, Kn-Kutnahorite, Li-Lithiophorite, Ma - Manganite, Mnt - Manganite,

Mm - Manganomelane, Ns - Nsutite, Rh - Rhodonite, Ro - Rhodochrosite, Rom - Romanechite, Ps - Psilomelane, Pyr - Pyrolusite, Tod -Todorokite 


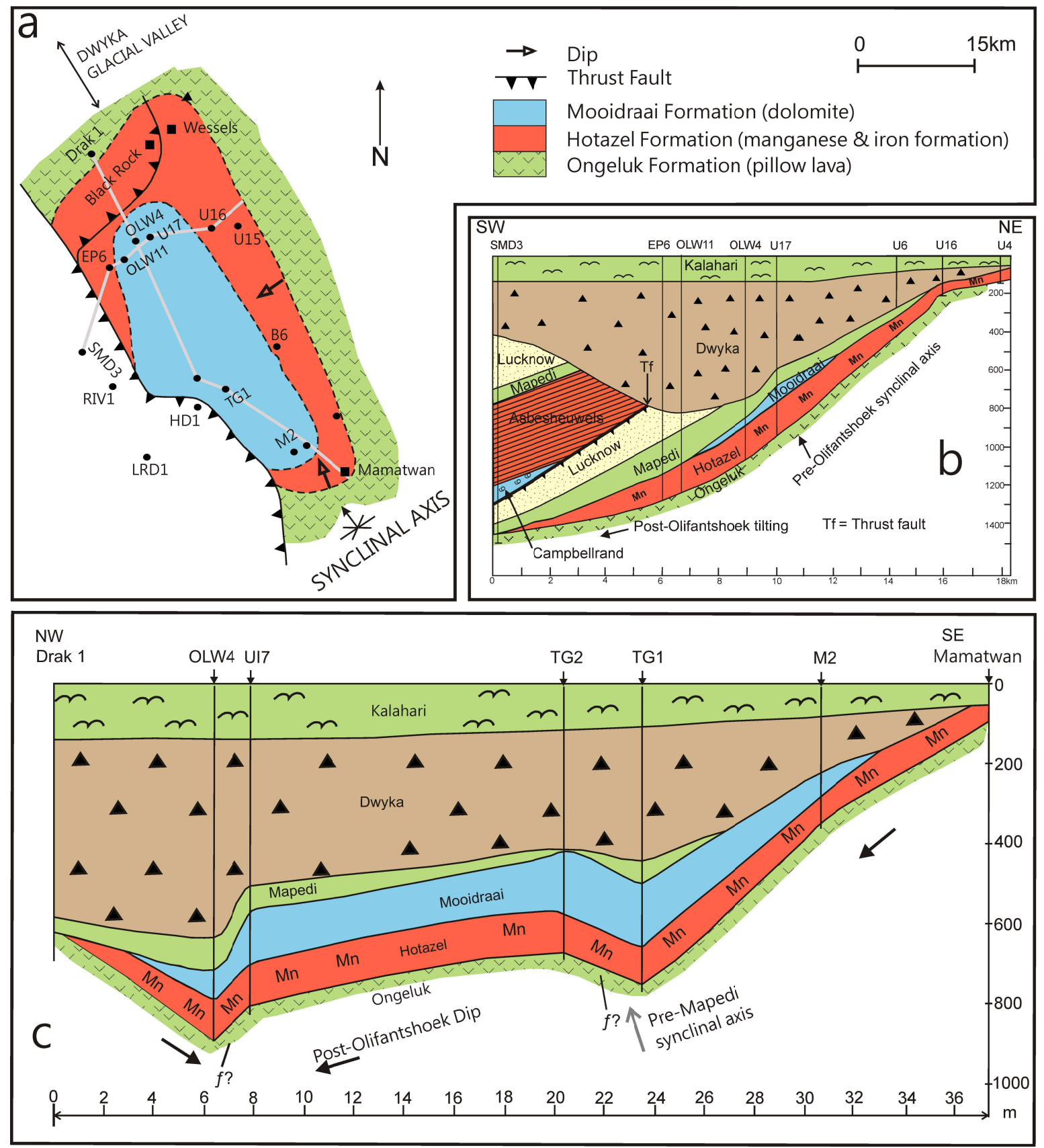

Fig. 5. (a) Simplified palaeogeological map of the Main Kalahari deposit of the KMF (b) with east-west (c) and north-south section. Note in $b$ the early synclinal structure cut by an erosional unconformity at base of the Mapedi/Gamagara Formation, the tilting of strata to the west and duplication by the Black Ridge thrust fault, as well as the presence of a deep early Permian Dwyka glacial valley and cover by a veneer of Kalahari sediments (modified from Cairncross et al., 1997).

hangingwall of the thrust (Fig. 6). The graben is developed parallel to several subsidiary north-south striking normal faults which are especially conspicuous in the northern part of the deposit, in the vicinity of the high-grade Wessels and N'Chwaning underground mines (Fig. 6). Other important geological features indicated on the map are the series of northeast-striking normal faults with associated diabase dykes and the boundary of stripping ratios of less than 7:1 (which is important for open cast mining), as well as the lower manganese ore bed of the Hotazel Formation along the eastern margin of the deposit (Fig. 6).

The three sedimentary manganese ore beds in the Hotazel Formation display very systematic and cyclical gradational relations with the iron-formation host rock, both at the top and bottom of each bed. In each bed there is a gradual transition from chert-rich banded iron formation into hematite lutite, with no chert banding and eventually braunite lutite (Fig. 7). The banded iron formation is represented by either hematite-facies jaspilite, especially in the lower part of the succession in contact with hyaloclastite and pillow lava of the underlying Ongeluk Formation, grading upwards into magnetitehematite, magnetite-carbonate, or magnetite-silicate facies banded iron formation (Nel et al., 1986, Gutzmer and Beukes, 1996a; Tsikos and Moore, 1997). The hematite lutite is composed of fine-grained dusty hematite or microcrystalline specularite cemented by kutnahorite. In contrast, the braunite lutite is composed of microcrystalline braunite 


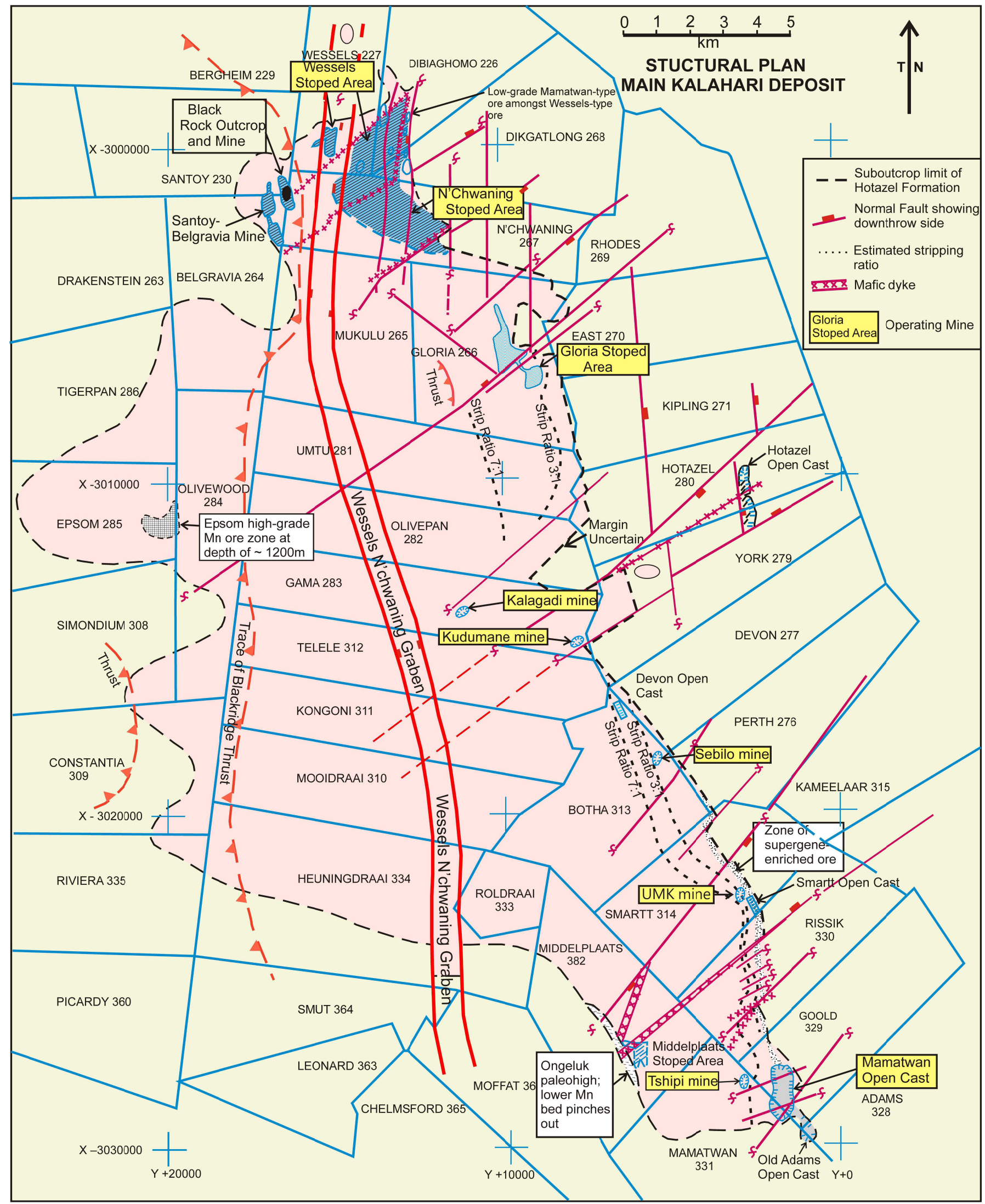

Fig. 6. Geological map of the Main Kalahari deposit of the KMF (shaded in pink) indicating existing producing mines (highlighted yellow), major structural features and stripping ratios to the ore beds (modified after Cairncross and Beukes, 2013). 


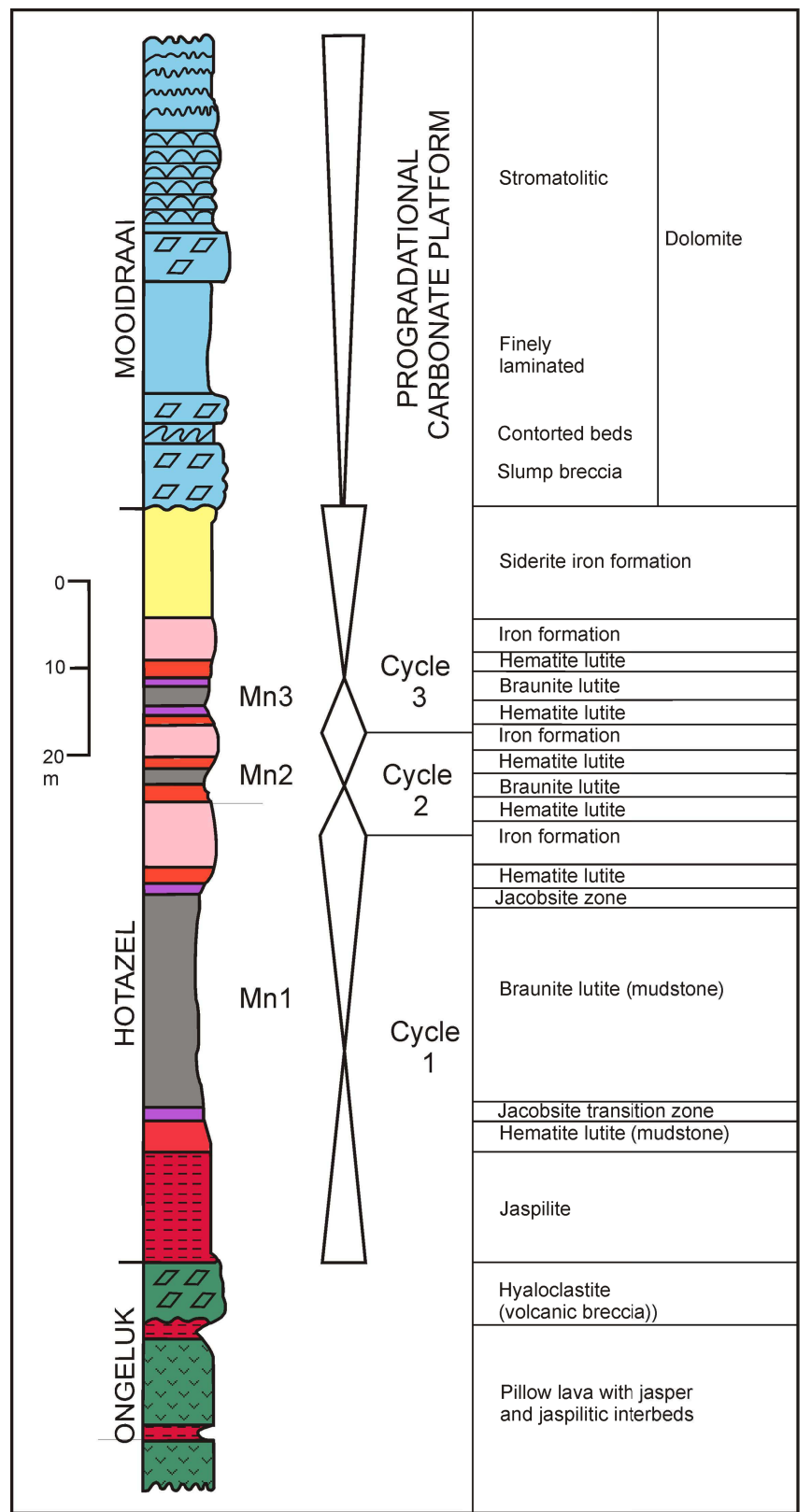

Fig. 7. Stratigraphy of the Hotazel and Mooidraai formations (modified after Cairncross et al., 1997). Note sedimentary cycles of iron formation through hematite lutite and jacobsitic hematite lutite into Mamatwan-type sedimentary braunite lutite ore beds.

with trace amounts of microcrystalline hematite, both cemented by kutnahorite with varying concentrations of millimeter-scale early diagenetic manganese carbonate ovoids (Nel et al., 1986; Gutzmer and Beukes, 1996a). Jacobsite is a common accessory mineral in the transition zone between hematite and braunite lutite (Fig. 7). A very interesting feature of the Hotazel Formation is that some of the ironformation beds are granular and display tiny wave-ripple crosslamination (Cairncross and Beukes, 2013). No such features are ever observed in any of the manganese ore beds that are typically microcrystalline and very finely laminated. This clearly indicates that some of the iron formation beds were deposited in shallower water, above at least storm wave base, whereas the manganese beds were consistently deposited in deeper water, below storm wave base (Cairncross and Beukes, 2013).
The Lower Manganese ore bed (Mn1 Fig. 7) is the best developed of the three beds throughout most of the deposit. It reaches a maximum known thickness of $45 \mathrm{~m}$ at Mamatwan Mine in the extreme southeastern corner of the Main Kalahari deposit, from where it thins rather gradually northwards, to a thickness of 5-8 $\mathrm{m}$ along the northern limit of the deposit, in the vicinity of the Wessels and N'Chwaning mines (Gutzmer and Beukes, 1997). The Upper Manganese ore bed (Mn1 Fig. 7) is relatively low-grade and commonly only about two meters or so thick which makes it uneconomical. However, in the southwestern corner of the deposit it is known to thicken rapidly to a maximum thickness of $32 \mathrm{~m}$ (Fig. 6). In other areas it may also thicken locally to several meters and with sympathetic increase in grade, it becomes mineable, as happened in several of the mines, most notably in the old Hotazel Mine (De Villiers, 1970). The Middle Manganese ore bed (Mn1 Fig. 7) is economically unimportant. It is invariably less than a meter thick and in many instances only represented by manganiferous hematite lutite (Gutzmer and Beukes, 1996a).

There are three main ore types present in the Main Kalahari deposit (Gutzmer and Beukes, 1996a), namely:

a) Low-grade primary sedimentary Mamatwan-type ore that contains 30 to 38.5 weight percent (wt\%) manganese metal (Table 2) and is composed of fine microcrystalline braunite, cemented by kutnahorite and containing abundant tiny concretionary ovoids and lenses of kutnahorite and manganese calcite.

b) High-grade Wessels-type ore containing 42 to $60 \mathrm{wt} \%$ manganese (Table 2), that is virtually devoid of carbonate minerals and composed of mixed assemblages of hausmannite, bixbyite, braunite II, and secondary coarse braunite.

c) High-grade supergene ore that is devoid of manganese carbonates and composed of Mn (IV) oxide minerals like cryptomelane, with a manganese metal content of 40 to $42 \mathrm{wt} \%$ (Table 2).

The low-grade sedimentary Mamatwan-type ore forms the bulk of the some 12 billion tonnes of in situ manganese ore with an average composition of just over 30wt\% manganese metal (Gutzmer and Beukes, 1996a). Most of the resource occurs in the Lower Manganese ore bed. Because of the relatively high manganese carbonate contents, the ore is self-fluxing and also ideally suited for producing sinter products (Chetty and Gutzmer, 2008) which have grades of up to 45-48 wt\% manganese metal (Table 2). In areas where it is well preserved, the Lower Manganese ore bed displays a well-developed zonation with stacked sedimentary cycles of kutnahorite and braunite-rich ore bands (Fig. 8), the latter containing higher manganese metal contents. There is also a hausmannite-rich zone with elevated manganese metal contents, developed in the lower part of the manganese ore bed and this zone, together with adjacent brauniterich bands, are often preferentially mined because of higher grades, relative to the basal and uppermost kutnahorite-rich zones (Fig. 8) and they produce a lumpy product with manganese metal contents of 37.6 to $38.5 \mathrm{wt} \%$ (Table 2).

High-grade Wessels-type ore only forms an estimated 3\% of the total known geological resource of the Main Kalahari deposit. This high-grade ore is very closely associated with north-south trending normal faults that displace the Hotazel Formation and overlying Mapedi Formation (Beukes et al., 1995; Gutzmer and Beukes, 1995; 1996a), particularly in the northern section of the Main Kalahari deposit, where it is mined underground at the Wessels and 
Table 2. Chemical composition* of typical lumpy manganese ore and Mamatwan sinter from the Kalahari Manganese Field (after Cairncross and Beukes, 2013)

\begin{tabular}{|c|c|c|c|c|c|c|c|c|c|}
\hline \multirow[t]{3}{*}{$\begin{array}{l}\text { Compo- } \\
\text { nent }\end{array}$} & \multicolumn{4}{|c|}{ High-grade Wessels-type Ore } & \multirow{3}{*}{ 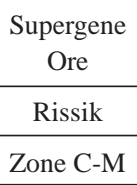 } & \multicolumn{2}{|c|}{$\begin{array}{c}\text { Sedimentary } \\
\text { Mamatwan-type Ore }\end{array}$} & \multirow{2}{*}{\multicolumn{2}{|c|}{$\begin{array}{c}\begin{array}{c}\text { Sintered } \\
\text { Ore }\end{array} \\
\text { Mamatwan }\end{array}$}} \\
\hline & \multicolumn{2}{|c|}{ N'Chwaning } & \multicolumn{2}{|c|}{ Wessels } & & Gloria & Mamatwan & & \\
\hline & $42 \%$ ore & $46 \%$ ore & W4L40 & W1L & & & & & \\
\hline Mn & 42.5 & 46.5 & 43.5 & 47.4 & 42.7 & 38.5 & 37.6 & 45.7 & 48.3 \\
\hline $\mathrm{Fe}$ & 12.5 & 10.6 & 13.7 & 11.8 & 5.2 & 5.2 & 4.7 & 5.6 & 5.5 \\
\hline $\mathrm{SiO}_{2}$ & 5 & 5.2 & 4.5 & 3 & 8.7 & 5.9 & 4.5 & 5.7 & 6.2 \\
\hline $\mathrm{P}$ & 0.03 & 0.03 & 0.04 & 0.04 & 0.02 & 0.02 & 0.02 & 0.02 & \\
\hline S & 0.13 & 0.12 & 0.09 & 0.12 & nd & 0.02 & 0.01 & 0.03 & \\
\hline $\mathrm{Al}_{2} \mathrm{O}_{3}$ & 0.3 & 0.3 & 0.4 & 0.5 & nd & 0.2 & 0.2 & 0.5 & 0.6 \\
\hline $\mathrm{CaO}$ & 8.8 & 5.8 & 7.2 & 6.2 & 1.63 & 12.3 & 13.9 & 16.7 & 14.5 \\
\hline $\mathrm{MgO}$ & 1.2 & 0.9 & 0.6 & 0.5 & 1.2 & 3.6 & 2.4 & 4.8 & 3.4 \\
\hline $\mathrm{K}_{2} \mathrm{O}$ & 0.01 & 0.01 & 0.03 & 0.02 & 1.23 & 0.03 & 0.04 & 0.04 & 0.03 \\
\hline $\mathrm{Na}_{2} \mathrm{O}$ & 0.03 & 0.03 & 0.19 & 0.27 & 0.46 & 0.04 & 0.05 & 0.05 & 0.04 \\
\hline B ppm & 600 & 700 & 856 & 806 & 44 & 450 & 287 & 270 & 316 \\
\hline
\end{tabular}

Sources:www.bhpbilliton.com (product enquiries); www.assore.com (ore sales); Du Plooy (2002). *Note concentrations expressed in terms of $\mathrm{Fe}$ and $\mathrm{Mn}$ metal values and not including loss on ignition so that values do not total to $100 \mathrm{wt} \%$.

N'Chwaning mines (Fig. 6). Similar high-grade ores were developed along normal faults in the graben structures that hosted the now virtually mined-out Hotazel and Langdon deposits (Figs. 4 and 6). The high-grade Wessels type ores display a very characteristic zonation outwards from the ferruginized normal fault zones. They typically comprise coarse-grained recrystallized secondary braunite ore immediately adjacent to ferruginized fault zones, followed by hausmannite-braunite, hausmannite-bixbyite and braunite II enriched zones, before grading into virtually unaltered braunite-kutnahorite Mamatwan-type ore (Fig. 9). The Wessels type ores are thought to have originated from leaching and residual enrichment of Mamatwan type ore by hydrothermal fluids that were expelled during the Kheis and Namaqua orogenic events at around 1.28-1.18 Ga and 1.045-1.01 Ga respectively (Gutzmer and Beukes, 1995, 1996a; Cairncross et al., 1997; Cairncross and Beukes, 2013). The older Kheis age is based on indirect palaeomagnetic dating of hematite in ferruginized fault zones (Evans et al., 2001) and the later Namaqua age on direct argon-argon dating on sugilite and norrishite, which form part of mineral assemblages in the Wessels-type ore (Gnos et al., 2003).

High-grade supergene ore, making up $<1$ percent of the total resource of the KMF, originated from weathering below the Kalahari

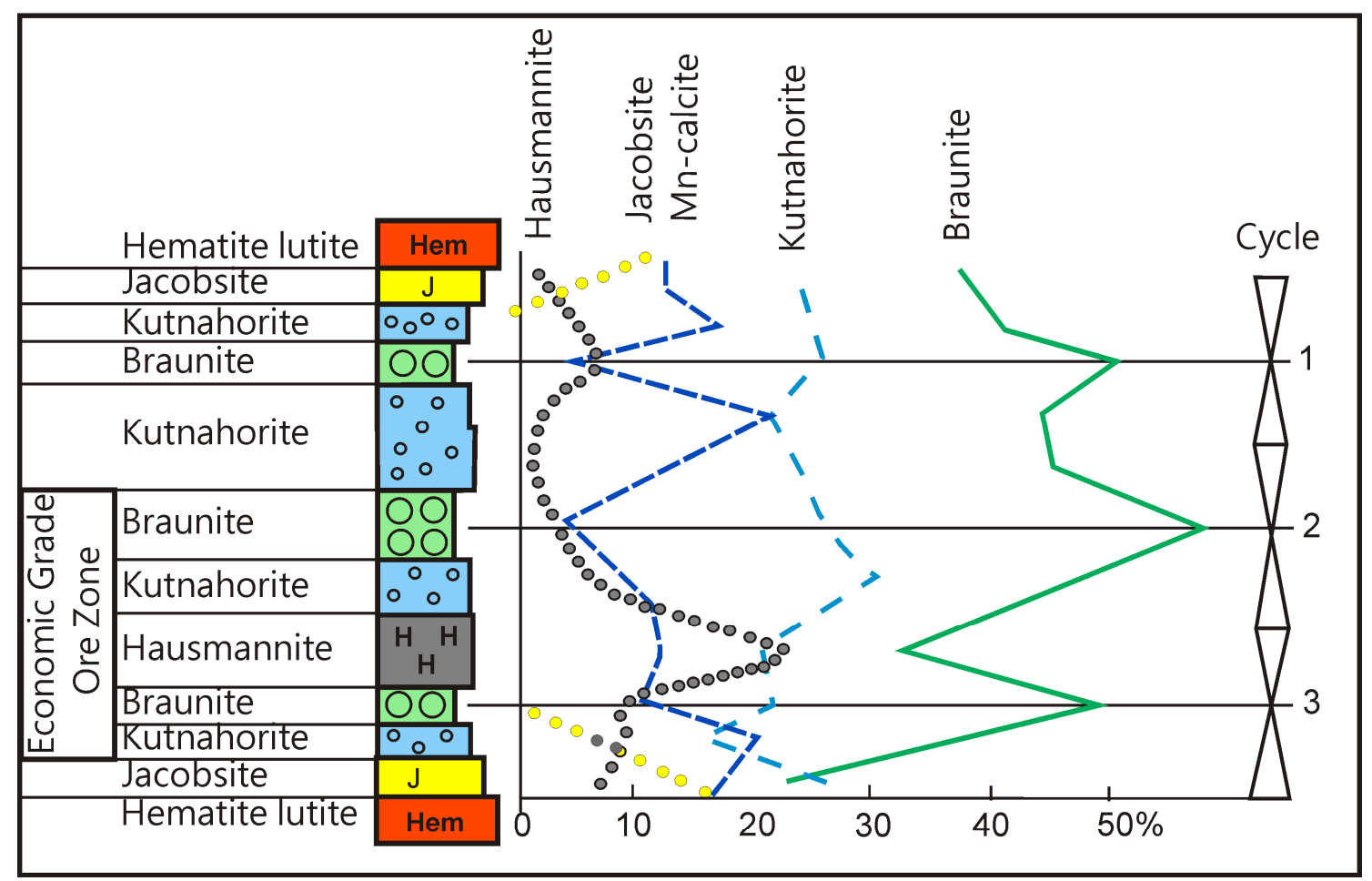

Fig. 8. Mineralogical zonation in the lower manganese ore bed of the KMF at Mamatwan Mine indicating the main economic ore zone with highest grades of around 37-38 wt\% Mn on average in Mamatwan-type ore (Modified after Nel et al., 1986; Cairncross et al., 1997). 


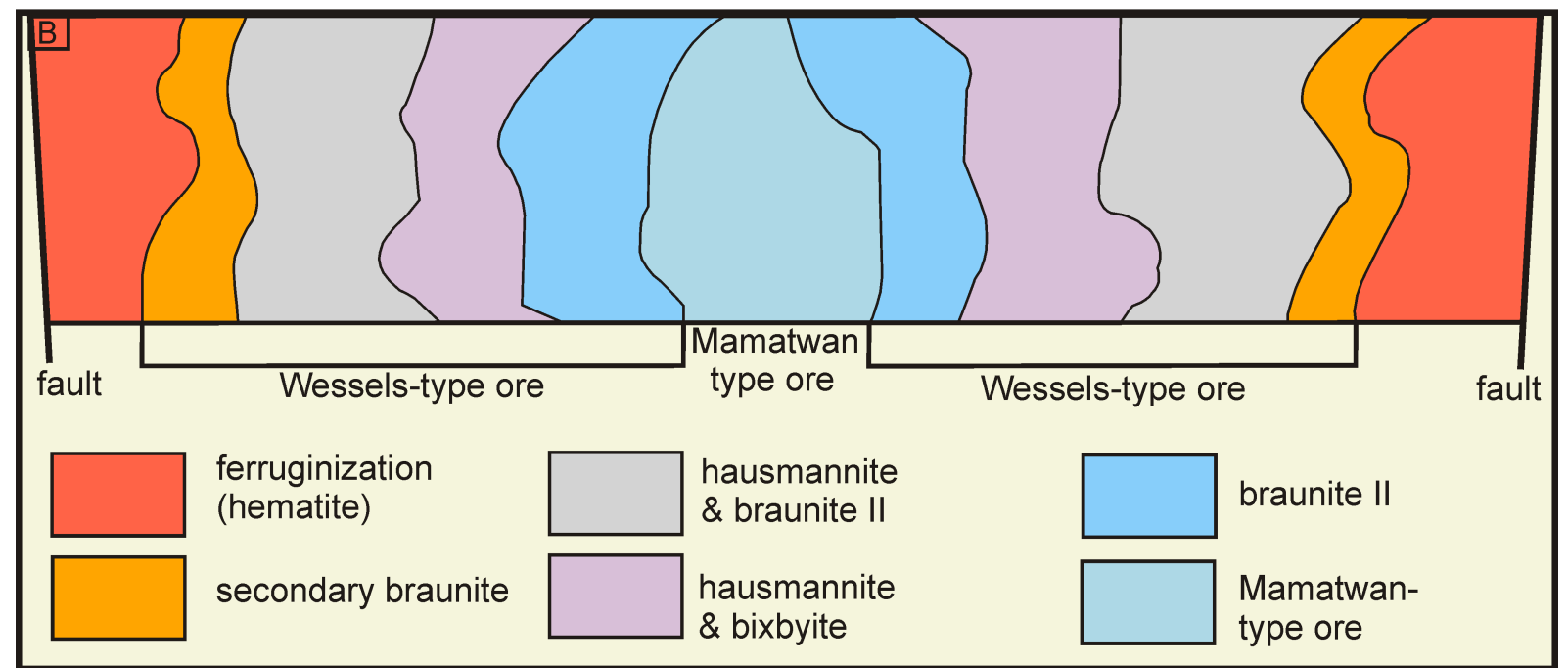

Fig. 9. Lateral zonation of Wessels-type hydrothermally altered manganese ore adjacent to normal faults in the Wessels and $N^{\prime}$ Chwaning underground mines in the KMF (modified from Gutzmer and Beukes, 1995).

beds along the eastern margin of the Main Kalahari deposit (Gutzmer et al., 2012). This weathering oxidized the carbonates in the primary low-grade Mamatwan-type ore to Mn (IV) manganese minerals. These ores contain slightly elevated potassium, relative to primary sedimentary Mamatwan-type ores, implying that it was introduced by meteoric water from surface during the weathering event. ArgonArgon dating of supergene-altered ore indicated that the first intensive weathering of the ores took place approximately 42 million years ago, prior to the deposition of Kalahari sediments. This was followed by several later, intensive alteration events at approximately 25 and 10 million years ago, with the most recent one believed to have occurred about 5 million years ago (Gutzmer et al., 2012; Cairncross and Beukes, 2013).

\section{Rooinekke Deposit, South Africa}

The Rooinekke manganese deposit (Fig. 1; Table 1) (Visser, 1954; De Villiers, 1960) is situated in the $\sim 2.4 \mathrm{Ga}$ Rooinekke Iron Formation of the Koegas Subgroup of the Ghaap Group of the Transvaal Supergroup, some $60 \mathrm{~km}$ to the south of Postmasburg, in Griqualand West (Fig. 4a). The deposit comprises of two ferruginous manganese ore beds, each $\sim 1 \mathrm{~m}$ thick, interbedded with clastictextured Rooinekke banded iron formation (Beukes and Gutzmer, 2008). The ores are composed of jacobsite, braunite, hausmannite and hematite with abundant recent supergene manganomelane and pyrolusite. Quartz and barite are common gangue minerals. The ore beds were mined, mainly in the mid 1990s, in two different operations, namely (a) by board-and-pillar method in the shallow underground Rooinekke Manganese Mine, to produce saleable manganese ore that contained on average about $35 \mathrm{wt} \% \mathrm{Mn}$ and 25-27 wt \% iron (Fe) (Visser, 1954) and (b) together with high-grade hematite iron ore, in an open pit on the adjacent Rooinekke Iron Ore Mine (Fig. 10a) where high-grade manganiferous iron ore was extracted.

It is important to realize that in the Rooinekke mining area the Rooinekke Iron Formation, with associated manganese-rich units are affected by the thick lateritic Wolhaarkop-Drakenstein palaeoweathering profile which developed regionally in Griqualand West, below the erosional unconformity at the base of the overlying
2.0 Ga Gamagara/Mapedi red bed succession of the Elim Group (Wiggering and Beukes, 1990; Holland and Beukes, 1990). It is the same unconformity that transects the Hotazel Formation in the Kalahari Manganese Field and along which ancient supergene, karsthosted manganese and iron ore deposits are developed on the Maremane dome between Postmasburg and Sishen (Fig. 10b) (Van Schalkwyk and Beukes, 1986; Cairncross and Beukes, 2013). Outside of the area affected by this palaeoweathering profile, Rooinekke iron formation is known to be composed of granular, siderite-rich chert bands, alternating with siderite and/or iron-silicate felutite bands with subordinate magnetite and traces of hematite (Nel, 2013). The iron formation is typically slightly manganiferous containing on average $\sim 3.0 \mathrm{wt} \% \mathrm{MnO}$, due to the presence of manganese-enriched siderite and ankerite (Nel, 2013), although some units contain higher concentrations of manganese (Johnson et al., 2013). Two such units enriched in rhodochrosite and kutnahorite, are known to exist because they have been intersected in deep drill core on the farm Sandridge, to the west of Rooinekke (Fig. 10a) and are considered to be protore to the manganese oxide ore beds developed in the WolhaarkopDrakenstein palaeoweathering profile in the Rooinekke mining area (Gutzmer and Beukes, 2002).

The iron and manganese ores in the area are thought to have developed as follows. At the Rooinekke Iron Ore Mine, where the pre-Gamagara/Mapedi unconformity is in direct contact with the iron formation, a high-grade ancient supergene hematite iron ore body is developed due to the leaching of silica and the transformation of earlier magnetite, iron carbonates and silicates, to hematite. At the same time the manganese carbonate-rich units may have been transformed to manganese wad that later recrystallized to a braunite- and hausmannite-bearing jacobsite-hematite manganese ore (Gutzmer and Beukes, 2002). The manganese-rich units also contain abundant barite that partly replaces earlier mineral assemblages and is ascribed to a later metasomatic alteration event, probably of similar age to the $\sim 1.1 \mathrm{Ga}$ Namaqua event that affected manganese ores in the Kalahari Manganese Field (Fig. 9). Rhodonite that replaces Mn-carbonates and chert in the deep drill core intersection at Rooinekke, is ascribed to the same alteration event (Gutzmer and Beukes, 2002). 


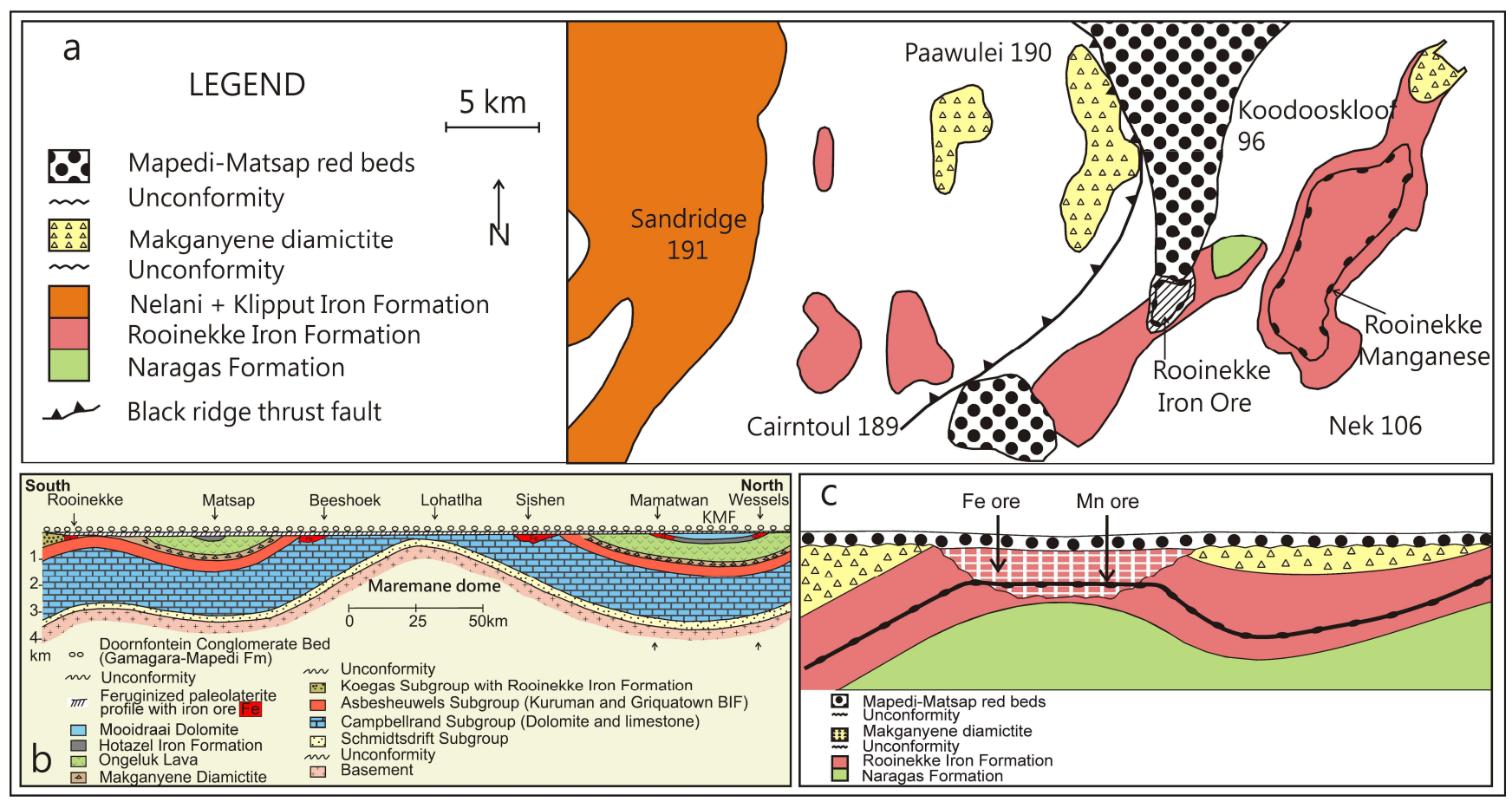

Fig. 10. (a) Simplified geological map of the Rooinekke mining area. (b) Regional setting of the iron and manganese ore in the lateritic palaeoweathering profile at the base of the Gamagara/Mapedi red bed succession (after Cairncross and Beukes, 2013). (c) Location of the Rooinekke iron ore mine in an anticlinal structure below the erosional unconformity with the adjacent manganese mine in a synclinal structure .

\section{Otjosondu Deposit, Namibia}

The BIF-hosted Otjosondu manganese deposit (Fig. 1; Table 1) is located some $150 \mathrm{~km}$ northeast of Windhoek at the eastern exposed extent of the inland central branch of the Late Neoproterozoic Damara Orogen in Namibia (Fig. 11). The deposit has produced some 0.55 Mt of high-grade ( $48 \mathrm{wt} \% \mathrm{Mn}$ ) beneficiated manganese ore since the 1950 s, from a series of open pits along the strike of the manganesebearing iron formation. The mine is currently dormant.

The manganese deposit consists of two, 4-7 m thick, sedimentary manganese ore beds bordering a central $30-40 \mathrm{~m}$ thick banded iron formation (Fig. 11) enclosed by quartzite. The iron formation unit, with associated manganese beds, is correlated with the Chuos Formation in the Khomas Subgroup of the Swakop Group, Damara Supergroup (Bühn et al., 1992). In the area of the mine, the lithogical succession is isoclinally folded and metamorphosed to upper amphibolite facies (Fig. 11).

Three lithotypes of manganese mineralisation are present, namely massive manganostone (a rock essentially composed of manganese minerals), banded manganostone and feldspathic manganostone, the latter related to an increasing admixture of siliciclastics with the original chemical manganese precipitate that is now represented by braunite \pm jacobsite (Bühnet al., 1992). The increasing siliciclastic admixture is reflected by increased proportions of manganese silicates (Mn clinopyroxene and garnet) and potassium (K)-feldspar in the ores, together with increasing concentrations of silicon $(\mathrm{Si})$, aluminium (Al), titanium (Ti) and zirconium ( $\mathrm{Zr}$ ). The massive manganostone, composed of braunite, hematite and jacobsite, represents the purest ores with very little siliciclastic admixture and therefore is the primary ore of the area, with grades of 33-47 wt $\% \mathrm{Mn}$ and $\mathrm{Mn} / \mathrm{Fe}$ ratios of 2.2-14.8 (Bühn et al., 1992). Unfortunately this ore type also contains high barium (Ba) contents of 2.8-7.8 wt\%, concentrated mainly in the mineral barite.

The manganese beds display very interesting relationships with the adjacent quartzites and iron formation. Both at the bottom and the top of the Chuos Formation, the manganostone is in sharp nongradational contact with clean orthoquartzite, suggesting the presence of hiatuses (Fig. 12a). However, the transition into iron formation is gradual with massive manganostone preferentially developed in direct contact with iron formation, both in the lower and upper part of the Chuos Formation (Fig.12a). Occasionally there are also thin feldspathic siliciclastic units developed in the iron formation. However, such units are more abundant in the manganese ore beds where transitions from massive manganostone through banded manganostone into feldspathic manganostone are well developed (Fig. 12a).

In other parts of the Damara succession, especially the northern platform area, the Chuos Formation is mainly composed of glacial diamictite that correlates globally with the $\sim 0.74$ Ga Sturtian Snowball Earth Event (Hoffman and Schrag, 2000). The presence of iron formation interbeds, so-called Rapitan-type iron formations, appears to be a characteristic feature of the Sturtian glacials (Macdonald et al., 2010). In some cases, as at Urucum in Brazil and Malyi Kingan in Siberia, the iron formations also contain interbeds of sedimentary manganese oxide similar to those at Otjosondu (Fig. 11d). However, the lateral extent of manganese beds is much more restricted than that of the iron formations. This is also the case in the Chuos Formation, where iron formations without manganese beds are known along the southern margin of the Damara belt near Windhoek and also in the Kaokoveld in the far northwest of Namibia (Fig. 11a). In this glaciogenic context and based on models of deposition derived from the Rapitan and Urucum areas, the siliciclastic 


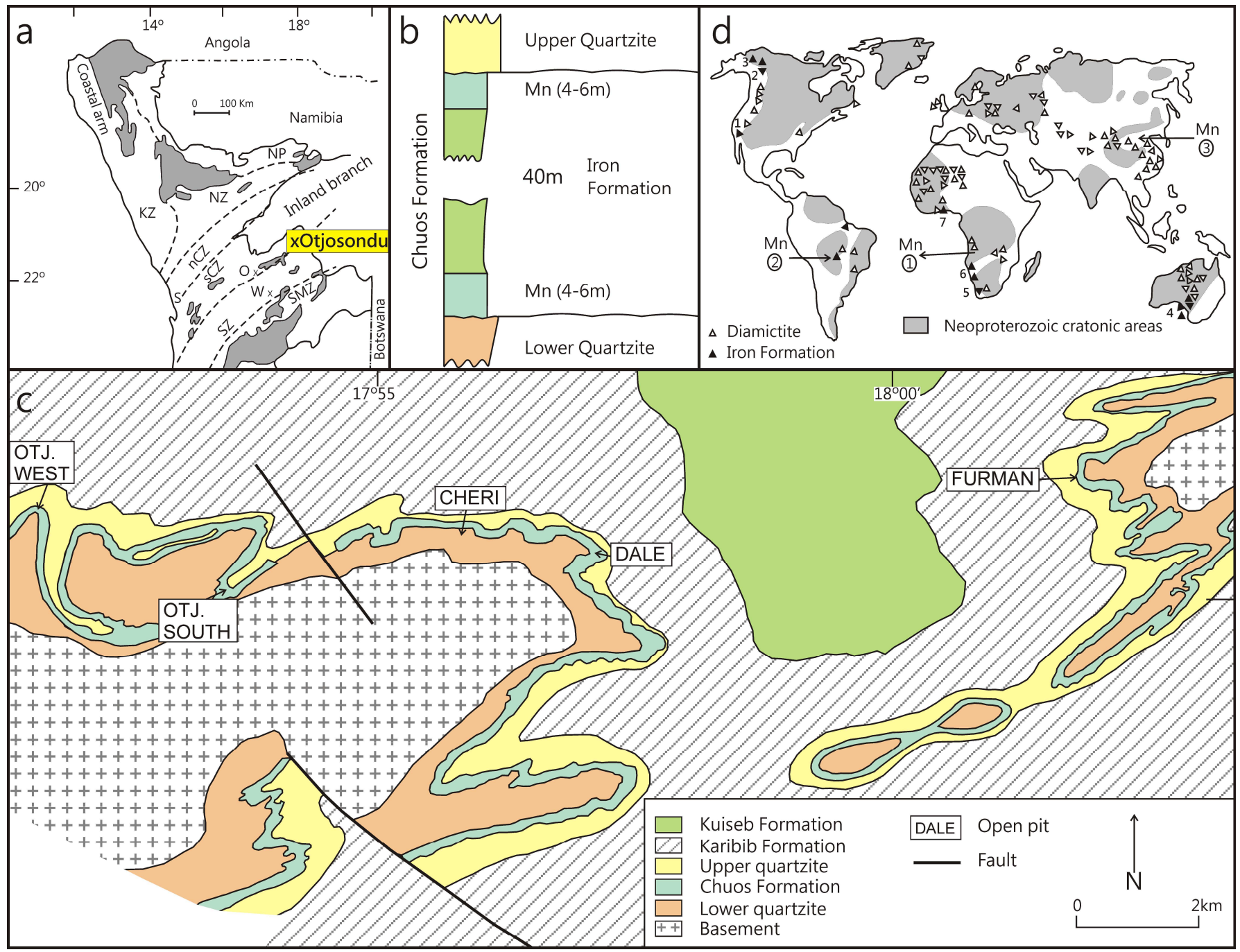

Fig. 11. (a) Regional geological setting of the Otjosondu BIF-hosted manganese deposit in the Damara orogenic belt of Namibia, (b) stratigraphic setting of manganese beds adjacent to iron formation of the Chuos Formation, (c) geological map of the Otjosondu mine area and (d) distribution of Neoproterozoic glacial deposits with location of BIF-hosted manganese deposits, namely $1=O t j o s o n d u, 2=U$ rucum and 3 = Malyi Kingan. (Compiled from Bühnet al., 1992 and Klein and Beukes, 1993).

debris present in the manganese and iron formation beds can be considered as submarine glacial-front outwash deposits, or melt-out debris from icebergs formed during the initial stages of breakup of the global ice cap, concomitant with a rise in sea-level (Fig. 12b). It is also during such interglacial episodes that dissolved iron and manganese, which accumulated in oxygen depleted stagnant deep ocean water below an ice cap, could well up onto shallow continental platforms through enhanced ocean circulation and precipitate as manganese and iron oxyhydroxides in oxygenated water. Because of their higher solubility and demand for free oxygen, manganese beds would have been deposited closer to shore than the iron formation beds (Fig. 12b)

\section{Black Shale-hosted Deposits}

\section{Francevillian Deposits, Gabon}

The manganese deposits of Gabon (Fig. 1; Table 1) are represented by supergene manganocrete developed on relatively unmetamorphosed and undeformed manganese-bearing black carbonaceous shale of the 2.3-2.0 Ga Francevillian Supergroup that overlies Archaean basement in the northwestern part of the Congo Craton (Weber, 1973). The deposits are the most significant manganese resource in Africa, outside of South Africa. They are large and shallow and amenable to open pit mining with high value oxide ore and are well served by the Trans-Gabonaise railway line linking the mining region with the Port of Owendo near Libreville. The resource at the start of exploitation in 1962 was declared to be $\sim 550 \mathrm{Mt}$ at $51 \mathrm{wt} \%$ $\mathrm{Mn}$ washed product. Currently there is a resource of $\sim 325 \mathrm{Mt}$ at $\sim 49 \mathrm{wt} \% \mathrm{Mn}$ (washed product), with a regional exploration potential for another 100-200 Mt (Swindell, 2015).

The deposits occur on flat plateaus that are incised by the Ogouee River and its tributaries (Fig. 13a). These plateaus, with an elevation of approximately $600 \mathrm{~m}$ above sea level, represent relicts of an old Cenozoic lateritized land surface. In simple terms, the manganese ore deposits are represented by manganocretes developed in areas where this surface developed on a manganiferous black shale unit in the argillaceous Bangombe Formation of the Francevillian Supergroup 


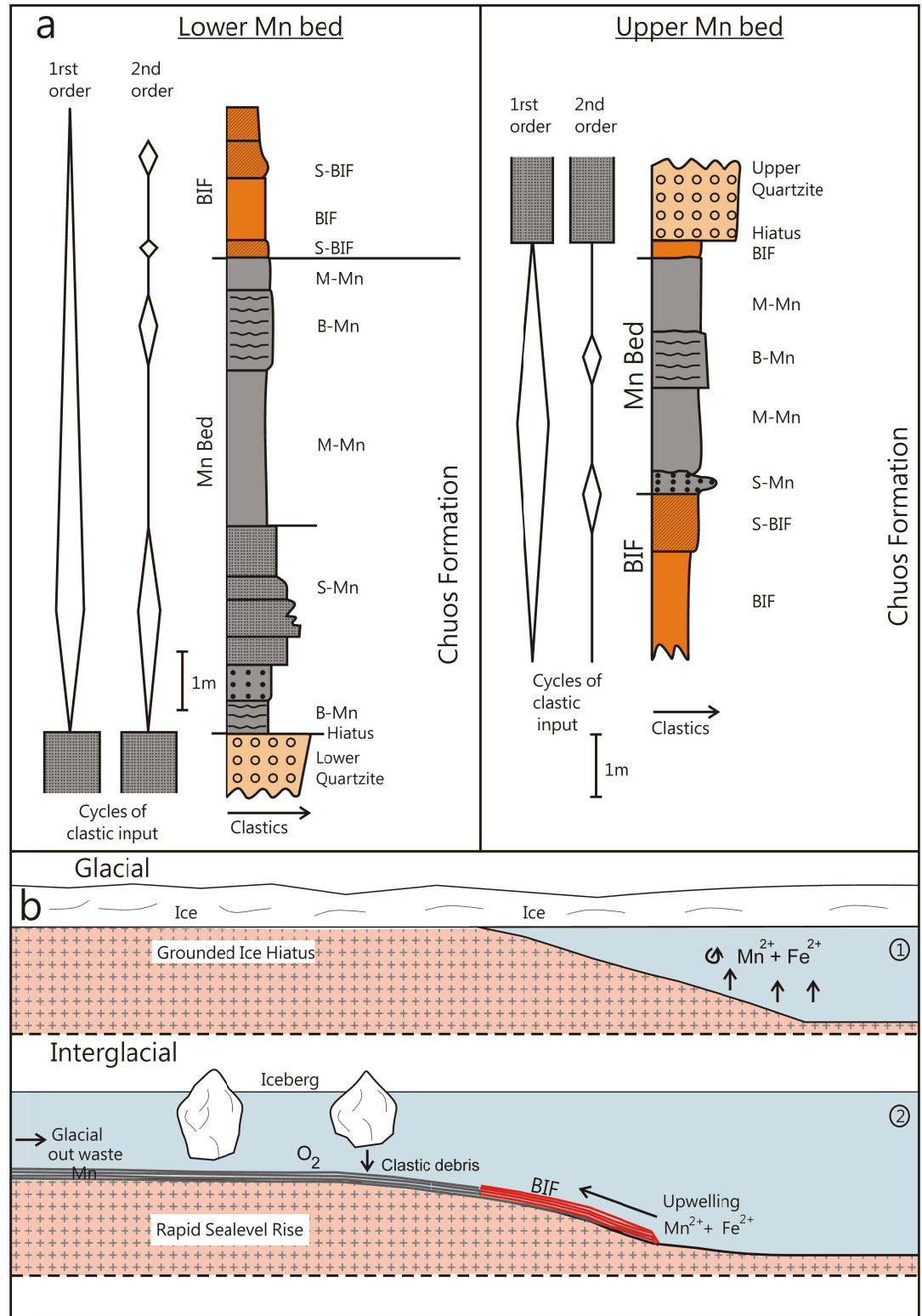

Fig. 12. (a) Detailed sedimentological setting of the lower and upper manganese bed at Otjosondu (after Bühn et al., 1992) and (b) depositional model, adapted in part from Klein and Beukes (1993). Abbreviations along stratigraphic columns: BIF = banded iron formation, $B=$ banded, $M=$ Massive, $M n=$ manganostone, $S=$ siliciclastic bands and particles present in beds (glacial outwash?).

(Fig. 13b). The black shale contains manganese carbonates and supergene processes have upgraded the manganese content from $15 \mathrm{wt} \%$ in the black shales to about $45 \mathrm{wt} \%$ in the ores (Petters, 1991).

There are a number of districts or clusters of plateaus that have manganese deposits associated with them. These include the Moanda, Franceville, Okondja and Lastoursville districts. The Moanda district (Weber, 1973, 1997; LeClerc and Weber, 1980), to the east of the town of Moanda, is the primary producing district. It consists of five well-defined plateaus namely Bangombe, Okouma, Bafoula, Masssengo and Yeye (Fig. 13a). Most of the production comes from the Bangombe plateau, with a mineralised surface of $19 \mathrm{~km}^{2}$ followed by the Okouma plateau with a surface area of $13 \mathrm{~km}^{2}$. The remaining three plateaus contain only low-grade ore. A section across the Bangombe plateau clearly illustrates how the manganese deposits are only developed where the old lateritic land surface intersected the manganiferous shale horizon in the Bangombe Formation (Fig. 13b). Where this horizon is protected from weathering by overlying non-manganiferous strata of the Francevillian Supergroup, manganese deposits are absent. The section also illustrates the incision of the manganocrete-capped plateau by tributaries of the Ogoee River (Fig. 13b).

The manganocrete profile of the Bangombe and Okouma plateaus near Moanda,ranges in thickness from about 9-17 m (Fig. 14a). It typically consists of a thin basal unit of massive manganese oxides and hydroxides composed of psilomelane, manganite, groutite, nsutite, and pyrolusite (Varentsov, 1964; Leclerc and Weber, 1980; Swindell, 2015). This basal layer is overlain by a platy (plaquette) zone, 3 to $9 \mathrm{~m}$ thick, with a similar mineralogy. The latter is overlain by an alumina- and iron-rich sub-economic manganiferous pisolite horizon. A thin transitional zone separates the two (Fig. 14a). The platy zone is the principal source of economic lumpy manganese ore.

In the Franceville region manganese ore bodies occur on 7 plateaus and the manganocrete profile (Fig. 14b) is consistent from plateau to plateau and compares well with that of the Moanda area (Fig. 14a). The grades of ore on these plateaus are in general lower than those of the Moanda area (Weber, 1973; Leclerc and Weber, 1980). More than $70 \%$ of production comes from the platyzone in the manganocrete with $10 \%$ from the high-grade but thin compact basal layer and the remainder from the transition zone. Mineralogically the ore in the Franceville area consists of cryptomelane and pyrolusite with some nsutite and lithiophorite set in a goethitic, clay and quartz matrix.

\section{Birimian Deposits, West Africa}

The large cluster of black shale-hosted carbonate manganese deposits with cappings of high-grade oxide ores in West Africa (Fig. 1; Table 1) is hosted by the middle Palaeoproterozoic Birimian Supergroup that flanks the Archaean Man Craton (Fig. 15). The two best-known and main deposits in the area are Nsuta in southern Ghana and Tambao in northern Burkina Faso. Smaller poorly described deposits are present at Mokta/Grand Lahou close to the coast in central Cote d'Ivoire and at Kiere in southwestern Burkina Faso (Fig. 15) and Ansongo in Mali (Fig. 1). Due to its remote location and lack of a railway link to harbor facilities, mining at Tambao has been very limited and sporadic. The same applies to Kiere where, although situated close to the Ouagadougou-Abidjan railway line, production has apparently been hampered by poor grade and lack of proper exploration. Virtually all the production from the area thus comes from Nsuta that produced about $0.5 \mathrm{Mt}$ of manganese metal from carbonate ore with a grade of 28-30 wt\% Mn in 2013 and Mokta/Grand Lahou, that produced some $0.3 \mathrm{Mt}$ of supergene oxide ore in 2011 (Corathers, 2014), at grades in the order of 40-46 wt\% Mn (Perseil and Grandin, 1978).

The Birimian Supergroup comprises a series of northwestsoutheast striking tectonically disrupted volcanic- and sedimentdominated orogenic belts with associated large volumes of syn- to 


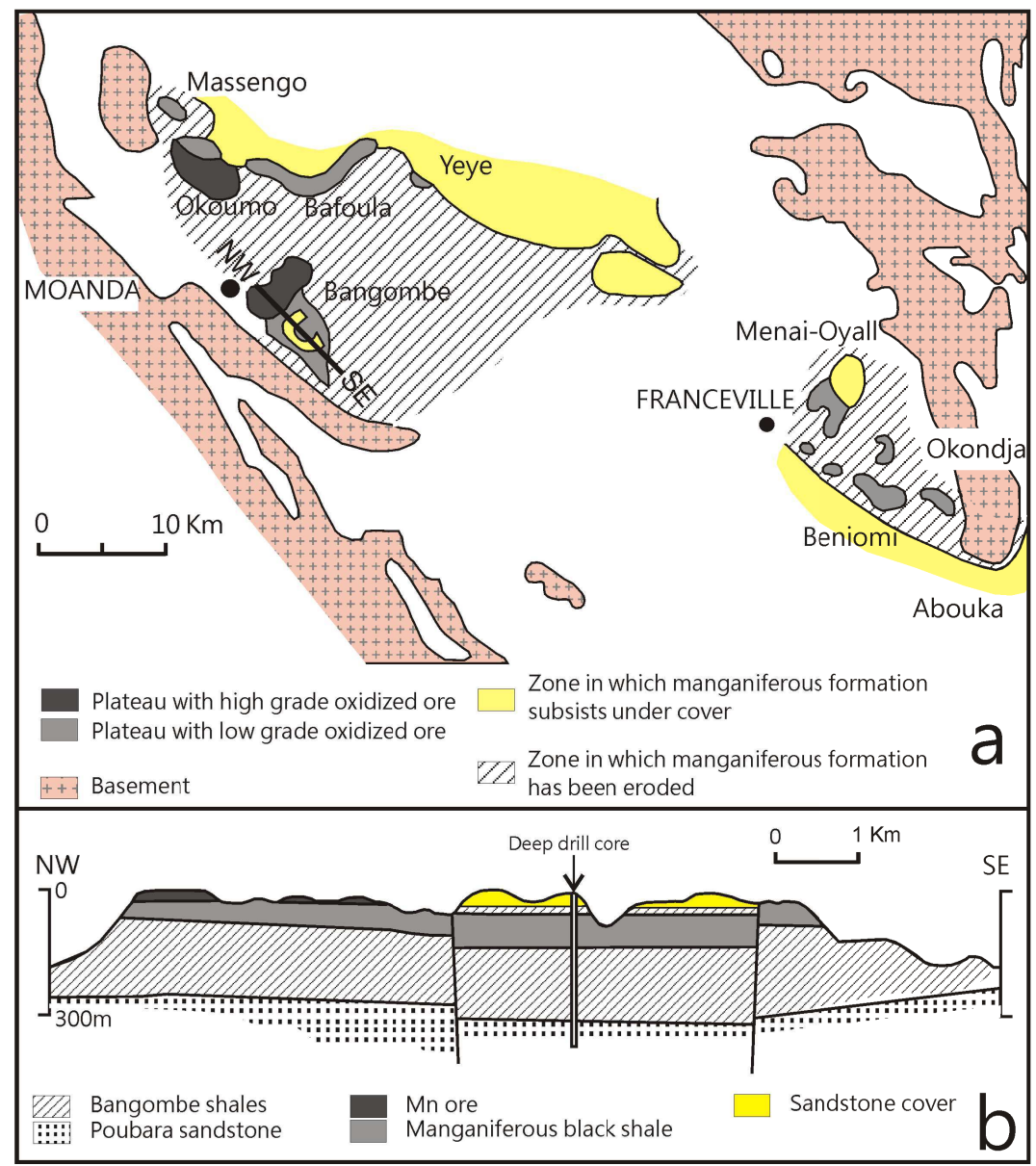

Fig. 13. Simplified geological map of the Francevillian succession in Gabon (a) and cross section of the Bangombe plateau near Moanda illustrating development of manganocrete above manganese-bearing black shale along a post-Gondwana land surface (b) (modified from Weber, 1973).

post-tectonic intrusive granitoids (Fig. 15). The succession has been metamorphosed to lower greenschist or upper greenschist facies with amphibolite facies conditions mainly restricted to some of the shear zones or metamorphic aureoles of granitoid intrusions (i.e. Baratoux et al., 2011). Locally the Birimian Supergroup is overlain with a marked angular unconformity by a fluvio-deltaic red bed succession known as the Tarkwaian Group, which predates some of the latest granitoid intrusions and shear zones in the area (Fig. 15). The volcanicdominated belts comprise two groups, namely mafic-dominated (bimodal tholeiitic and calc-alkaline lavas and volcanic products) and felsic-dominated (mainly felsic volcanics with some intermediate volcanics) (Fig. 15) both with minor argillite, chert and manganesebearing horizons.

The volcanic belts are considered to represent a series of ancient island arc systems that accreted onto the Man Craton during the Eburnian orogeny with contemporaneous sedimentation in adjacent basins and the intrusion of juvenile granitoids (Baratoux et al., 2011). Stratigraphic and radiometric age data suggest mafic volcanism was dominant during the early phases of development of the Eburnian orogeny at 2.2-2.17 Ga and was followed by a major phase of felsic volcanic activity at around 2.17-2.16 Ga and flysh-type siliciclastic turbidite sedimentation at 2.16-2.12 Ga (Fig. 15). Uplift and erosion at around 2.12-2.10 Ga preceded deposition of the Tarkwaian red bed succession that was, in turn followed by the development of the major set of north- to northeast-trending transcurrent faults at ca 2.0-1.9 Ga (Fig. 15) (Baratoux et al., 2011).

Manganese deposits of the area are situated in two different settings. Those of Ghana in the vicinity of Nsuta, all appear to be associated with upper strata of mafic-dominated volcanic belts in the transition zone to overlying sediment-dominated belts (Fig. 15). In contrast, all the deposits of Côte d'Ivoire and Burkina Faso, including Mokta/Grand Lahou, Kiere and Tambao, are located in the series of long, narrow, felsicdominated belts that appear to be more abundantly developed along the western side of the Birimian terrain with mafic-dominated belts being more common to the east in Ghana (Fig. 15). It would thus appear as if there were at least two major periods of manganese deposition in the area but the possibility that they all formed contemporaneously in different facies of an original, much larger basin that was later structurally disrupted, cannot be excluded.

In both the mafic- and felsic-dominated volcanic belts, the manganese protore to supergene manganese oxide ore cappings is composed of manganese carbonate (mainly rhodochrosite) beds, containing in the order of 20-30 wt \% Mn (Fig. 16). Differences from one area to the other are related to varying admixtures of siliciclastic impurities in the carbonates and degree of metamorphism. Siliciclastic impurities are mainly manifested by development of spessartine garnet and sericite in areas of greenschist facies metamorphism such as at Nsuta (Nyame, 1998, 2001; Nyame et al. 1998). In amphibolite-facies terrains rhodonite is a common additional mineral due to the reaction of manganese carbonates with silica (Melcher, 1995).

The supergene oxide ore caps are developed over thicknesses of up to $70 \mathrm{~m}$ and generally form positive topographic ridges (Swindell, 2015). The ores are generally of high-grade, containing 45-50 wt $\% \mathrm{Mn}$ and vary texturally from vuggy, botryoidal, massive, to bedded and vein-like in character. They are normally composed of Mn (IV) oxide minerals such as psilomelane, pyrolusite, cryptomelane and nsutite. However, those developed over gondite may also include braunite (Swindell, 2015). The supergene oxide core is often overlain by manganese pisolites and manganiferous laterite and tends to be bordered by eluvial manganese boulders and blocks, so that the oxide capping is typically mushroom shaped in cross-section (Fig. 16). Finer detrital ores (nodular masses and pellets, the consequence of local weathering and erosion) are invariably developed further downslope in aprons along the flanks of the hills (Fig. 16).

The supergene Mn (IV) oxide ore caps, that are seldom more than 10-20 Mt in size, constitute premium high-grade metallurgical ores with high $\mathrm{Mn} / \mathrm{Fe}$ ratios. It is only at Nsuta, where mining has taken place since 1916, that the oxide ores became exhausted in 1997 and since then low-grade carbonate (rhodochrosite) ore, with a grade of 28-30 wt $\% \mathrm{Mn}$, has been mined.

The 30-40 m thick manganese carbonate bed at Nsuta (Mücke et al., 1999) is interbedded with fine-grained black carbonaceous shale that grades downwards below and upwards above, the ore bed into a succession of greywacke and shale, with excellent examples of Bouma sedimentary cycles typical of deposition from turbidites (Van Bart, 


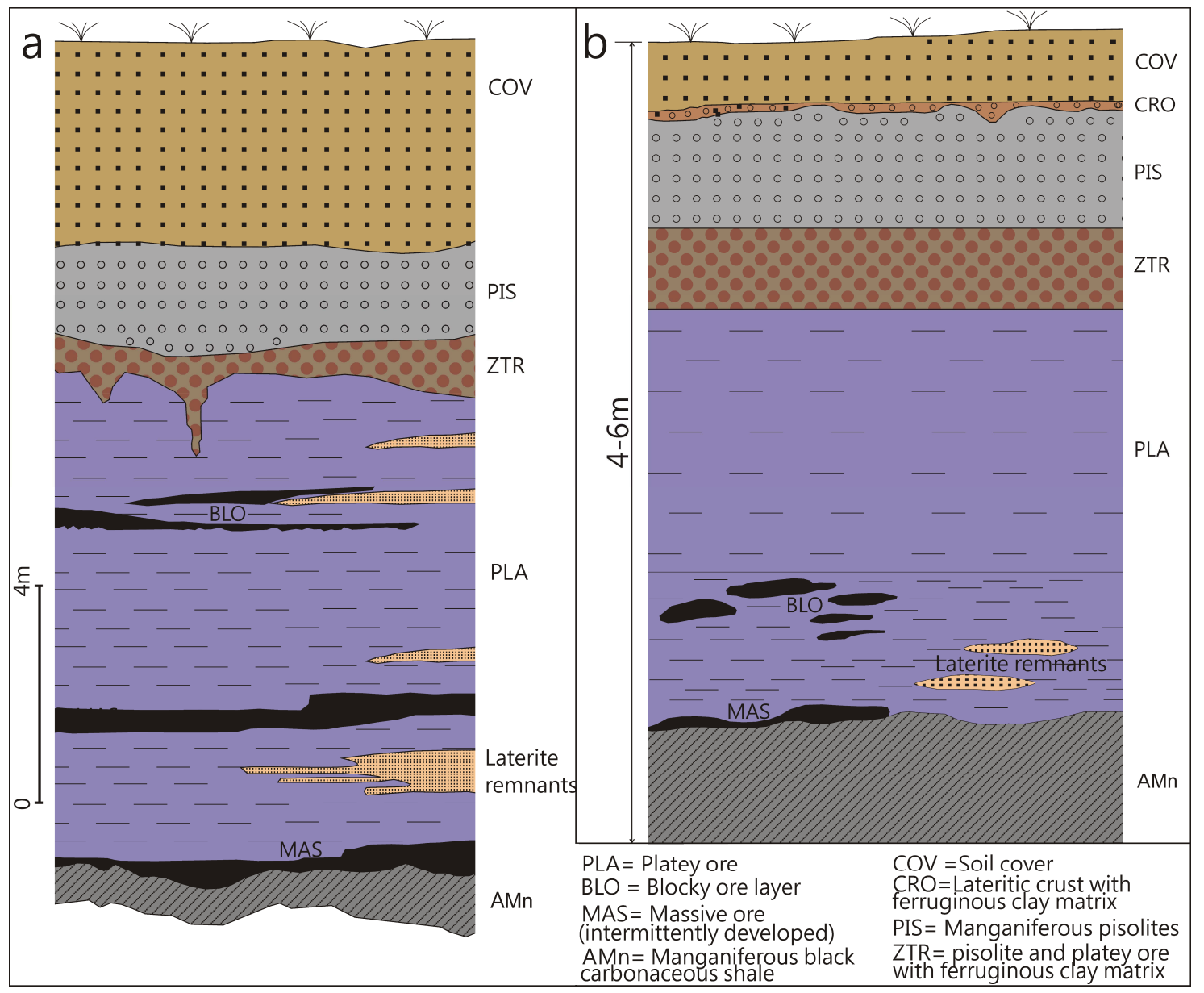

Fig. 14. Zonation of supergene ore types in the manganocrete profile in the (a) Moanda and (b) Franceville areas. The Moanda profile is after Weber (1973) and that of Franceville after Swindell (2015).

2001; Tetteh, 2010). In sequence stratigraphic terms it would thus appear as if the manganese carbonate bed was deposited during a period of maximum flooding of the basin, removed from siliciclastic input ahead of a turbidite fan system (Fig. 17). The greywacke succession is in turn overlain and underlain by andesitic greenstone composed mainly of volcaniclastics and pyroclastics with subordinate lava (Van Bart, 2001; Nyame, 2008; Tetteh, 2010).

The manganese-bearing sedimentary unit of Nsuta is very extensive and can be traced for more than $300 \mathrm{~km}$ along the flanks of a regional west-verging, north-northeast to south-southwest striking, steeply overturned synclinal structure, that is unconformably overlain by the Tarkwaian Group in the northwest (Fig. 18a). Nsuta Mine is located in a parasitic anticlinal to synclinal structure infolded into lower greenstone along the western flank of the regional syncline (Fig. 18a), where mining took place in five structurally delineated areas known as hills A-E (Fig. 18b). The Hill D North and South deposits, forming part of a double folded synclinal structure has been the main production area at Nsuta in recent years.

The least altered sedimentary ore at Nsuta varies in character from dark grey carbonaceous micritic to medium grey fine crystalline manganese carbonate, with a laminated to massive appearance (Van Bart, 2001). The dominant carbonate mineral throughout is rhodochrosite with, in certain cases, kutnahorite present. The micritic ore is dominant in most of the deposit. Locally this ore has been enriched by hydrothermal alteration that is expressed by an abundance of cross-cutting veins or massive replacement bodies of coarse to very coarse granoblastic pink rhodochrosite. This type of ore is typically of higher grade than the fine-grained sedimentary ores and is especially abundant in Hill D South (Nyame, 1998; Nyame et al., 2003; Tetteh, 2010).

The Tambao deposit in northern Burkina Faso (Fig. 15) (Perseil and Grandin, 1978) is considered one of the major manganese prospects of West Africa with a proven supergene manganese oxide ore reserve of $4.6 \mathrm{Mt}$ at $50.98 \mathrm{wt} \% \mathrm{Mn}$ and additional resources of 14-17 Mt at 51.5 wt\% Mn (Swindell, 2015). The deposit essentially consists of a steeply dipping, thick manganese ore bed, split into three bands ("Layers 1-3") by an intrusive granite sill (Fig. 19). The supergene ores are composed of cryptomelane, pyrolusite and nsutite. The protore below the supergene oxide capping consists of $70 \%$ rhodochrosite (with minor hausmannite, braunite and manganosite) and 30\% rhodonite and tephroite. It has grades of 36-55 wt $\% \mathrm{Mn}$ (Swindell, 2015).

The Tambao deposit may be part of a potentially much larger mineralised manganese field. This is suggested by the presence of the geologically similar Ansongo manganese deposit situated approximately $120 \mathrm{~km}$ to the northeast of Tambao, close to the Niger River in Mali (Fig. 1). Mineralised rocks in the Ansongo area occur over a strike length of $20 \mathrm{~km}$, with a resource of supergene oxide ores estimated at about $8 \mathrm{Mt}$, with grades in the order of 30-45 wt\% Mn (Swindell, 2015). 


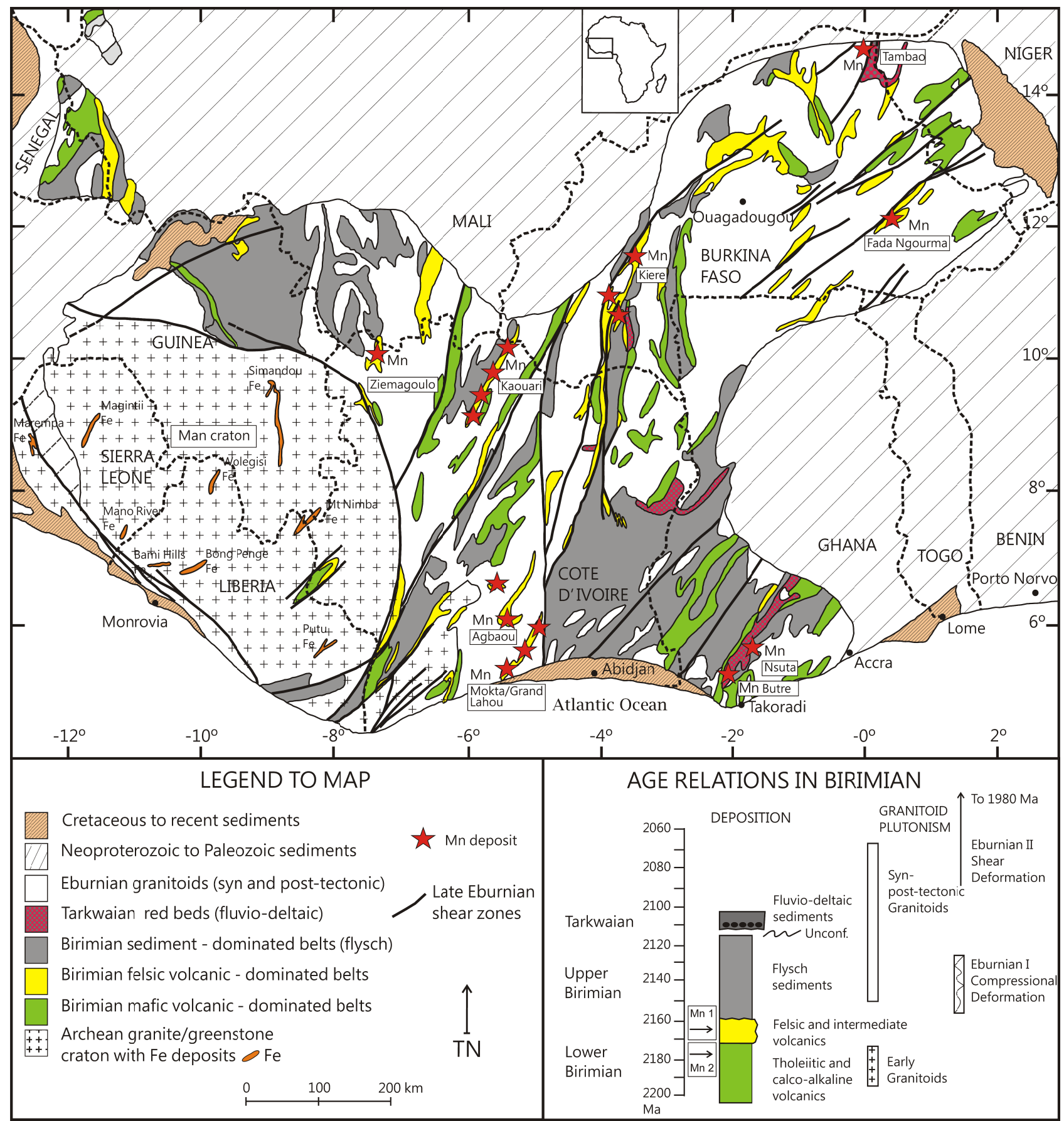

Fig. 15. Simplified geological map of the Birimian succession in West Africa showing major volcanic-and sediment-dominated orogenic belts, the Man Craton, tectono-sedimentary development of the successionand location of black shale-hosted carbonate/gondite manganese deposits (based on West African Geological Map by SEMS Exploration compiled from BRGM geological data; tectono-sedimentary development from Baratoux et al., 2011).

\section{Kisenge Deposit, DRC}

The Kisenge manganese deposit in the Democratic Republic of the Congo (Fig. 1; Table 1) is situated in metamorphosed sedimentary strata of the Lukoshi Complex, off the southern margin of the Archaean Congo Craton. The depositional age of the succession is poorly constrained but is considered to have taken place at $\sim 2.1$ $2.2 \mathrm{Ga}$, essentially contemporaneously with that of the Francevillian succession on the northwestern side of the Congo Craton (Feybesse et al., 1998; Bekker et al., 2003). Thrust deformation and medium to high-grade metamorphism took place during the late Eburnian at about 2.0-2.1 Ga (Feybesse et al., 1998).

In plan view the deposit consists of four lenticular, high-grade supergene manganese oxide ore bodies overlying carbonaceous manganese carbonate protore interbedded with carbonaceous phyllite (Doyen,1973). It was mined between 1956 and 1977, until closure of the Benguela railway line and produced $\sim 330,000$ tonnes per annum of high-grade (> $46 \mathrm{wt} \% \mathrm{Mn}$ ) washed supergene Mn (IV) oxide ore. Before mining operations started, the supergene ores outcropped in the form of a series of four east-west striking hills rising some 


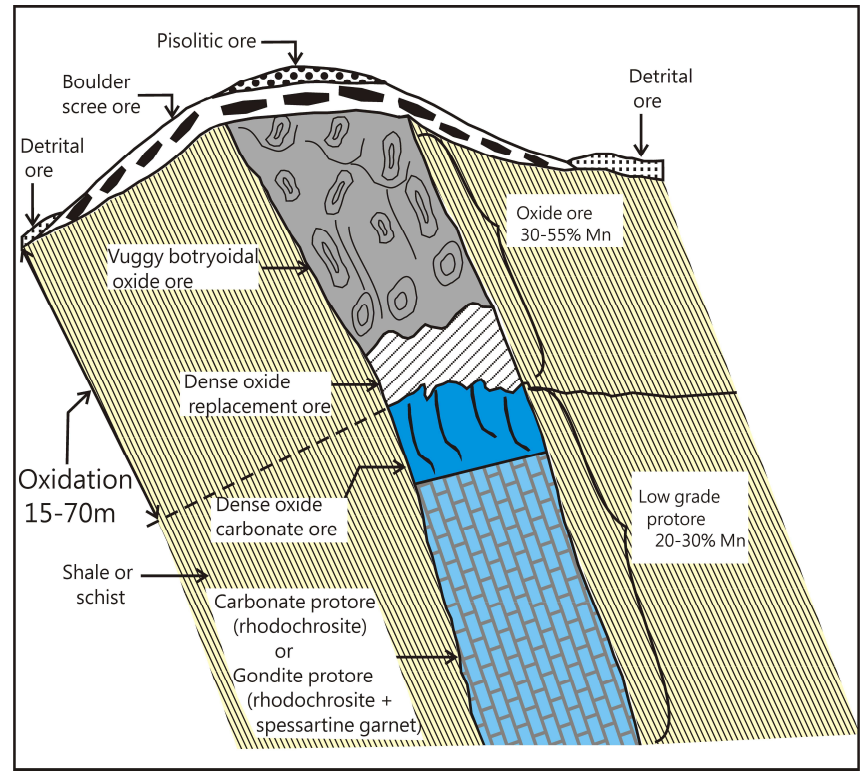

Fig.16. Schematic diagram of a typical supergene-enriched manganese oxide ore capping a carbonate or gondite black shalehosted manganese bed of the Birimian in West Africa (modified after Swindell, 2015).

20-40 m above a laterite-capped peneplain, with an elevation of $1,100 \mathrm{~m}$ above sea level. The peneplain is preserved between the incised valleys of the Lukhoshi and Luashi rivers (Fig. 20a). Another supergene manganese oxide body is known to occur at Muengenge, some $12 \mathrm{~km}$ east of Kisenge (Fig. 20a).

At Kisenge the manganese ore beds occur in a succession dominated by sericite schists dipping steeply to the south at between 45 and 90 degrees. Manganese mineralisation is restricted to a zone close to the contact of the sericite schists with an overlying amphibolite schist unit containing gabbroic bodies. The latter is in contact with a granite and migmatite body (Fig. 20b) and it is not clear from descriptions available whether this is a normal succession with an intrusive granite body, or an overturned succession with a granitic basement.

Two manganese carbonate protore beds are present and are in the order of $40 \mathrm{~m}$ thick. They are separated by manganiferous garnetbearing carbonaceous phyllite (Fig. 20c). High-grade supergene manganese oxide ores with grades of 38-51 wt $\% \mathrm{Mn}$ are developed above manganese carbonate protore beds that have grades of 30$40 \mathrm{wt} \% \mathrm{Mn}$. The supergene ores, developed down to depths of $80 \mathrm{~m}$ below surface, are composed of cryptomelane and pyrolusite. The carbonate protore is mainly composed of rhodochrosite and is very dark grey in colour due to a high organic carbon content.

\section{Karst-hosted Deposits}

\section{Postmasburg Manganese Field, South Africa}

The karst-hosted Postmasburg manganese field (Fig. 1; Table 1) was the main source of manganese ore in South Africa for about three decades between $\sim 1930$ and $\sim 1960$ when mining in the Kalahari manganese field really started to take off. Since then production from the Postmasburg manganese field dwindled to virtually nothing in the late 1980 s to early 2000 s with an increased small and inconsistent production in more recent years.

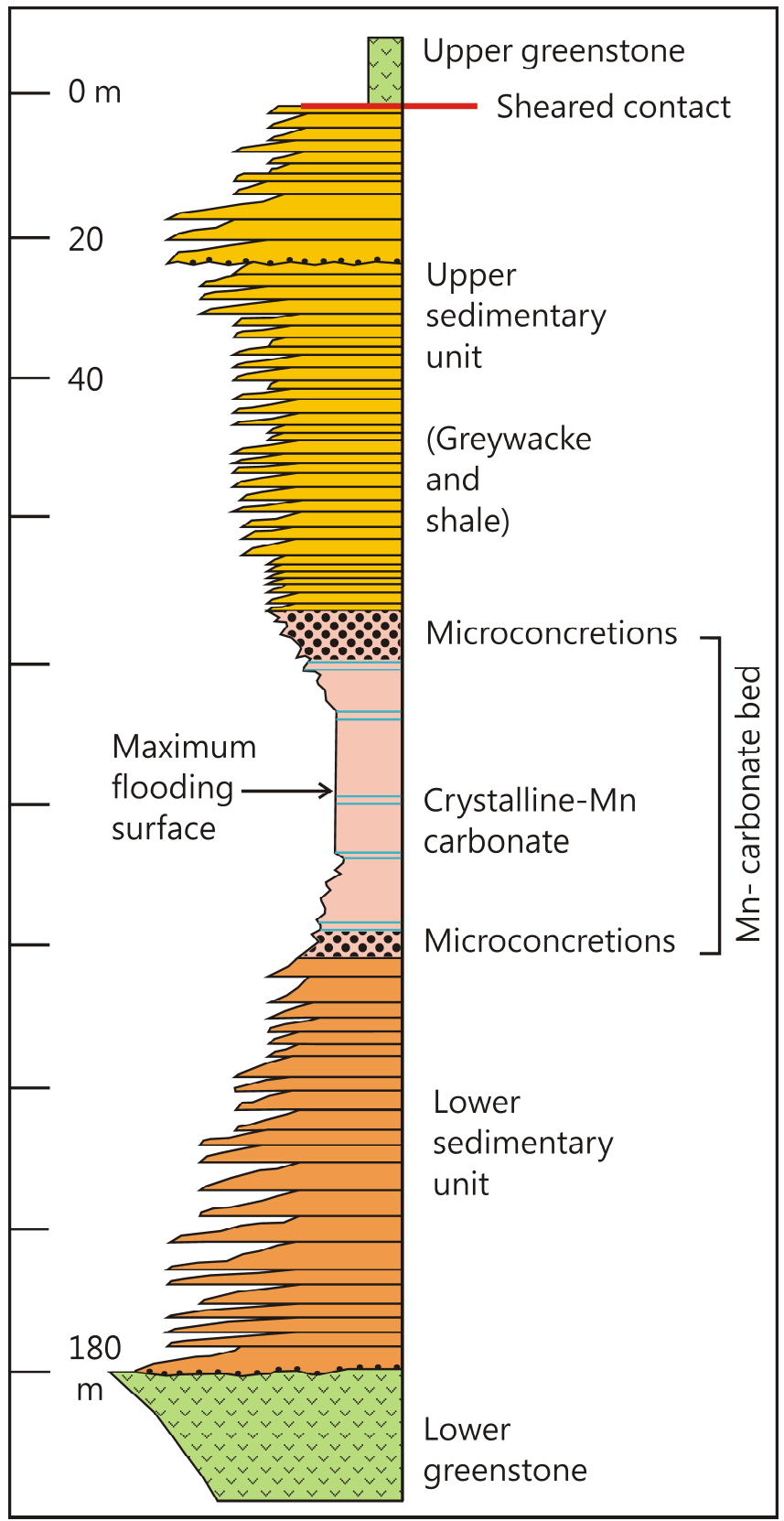

Fig. 17. Stratigraphic and sedimentological setting of manganese carbonate ore bed at Nsuta Mine, Ghana (modified after Van Bart, 2001).

The manganese field, situated on the Maremane dome between Sishen and Postmasburg in the Northern Cape Province of South Africa (Fig.4a), hosts two types of manganese ores associated with palaeokarst features on the Neoarchaean Campbellrand dolomite succession that outcrops in the core of the dome (Fig. 21a). The one type, referred to as siliceous manganese ore, occurs as pockets in a chert- and silica-rich solution collapse breccia, known as the Wolhaarkop Breccia and forms the so-called Eastern Belt of the manganese field (Figs. 21a and b) (Gutzmer and Beukes, 1996b). The second type, referred to as ferruginous manganese ore, occurs as lenticular bedded stratiform units immediately above the erosional unconformity that separates the red beds of the $\sim 2.0$ Ga Gamagara Formation from the underlying Neoarchaean Campbellrand dolomites in the center of the dome between Glosam, Lohatha and Gloria 


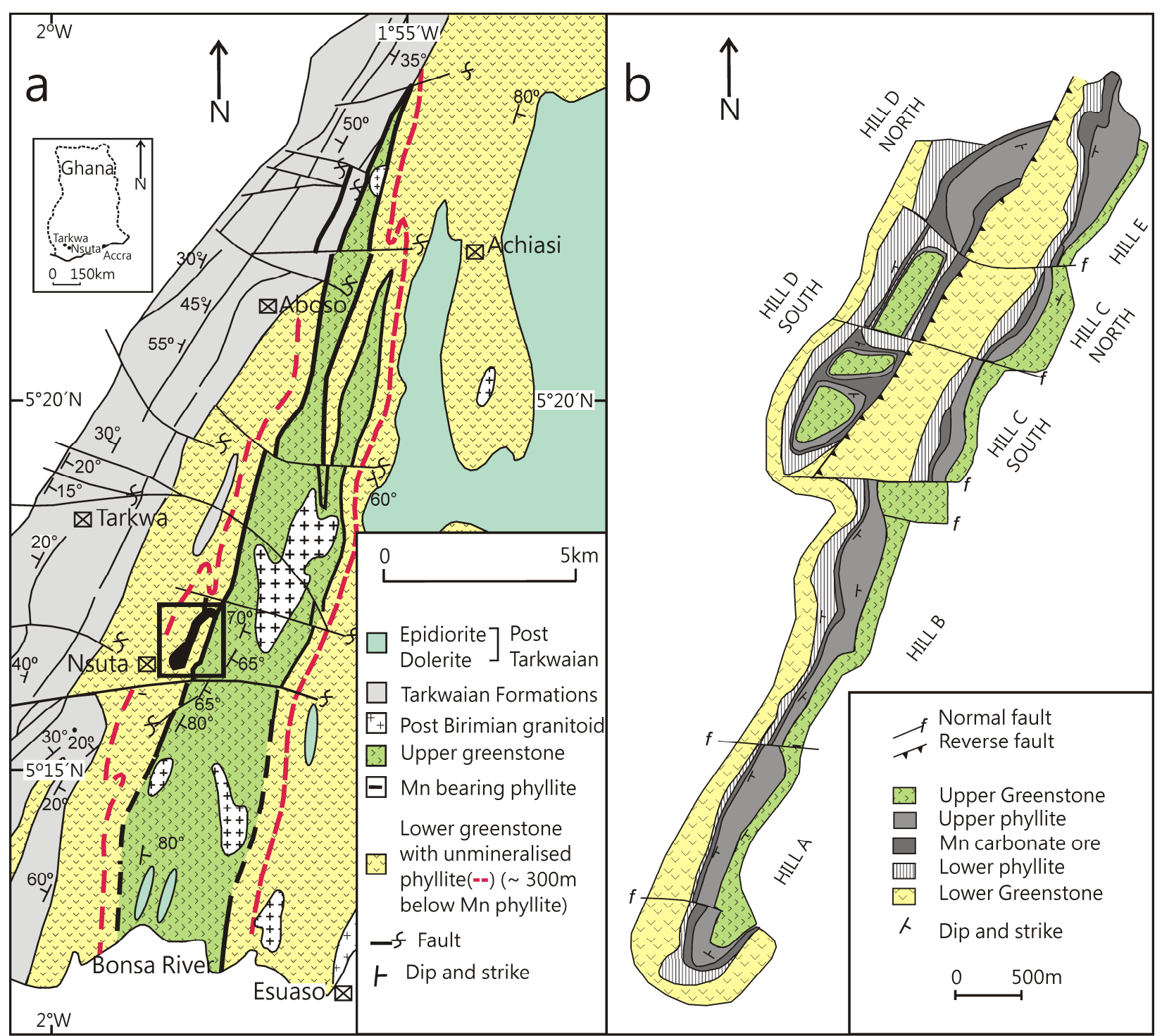

Fig. 18. (a) Map showing the regional distribution of the manganese-bearing unit in the Nsuta area (modified after Service, 1943). (b) Simplified geological map of the Nsuta manganese deposit (modified after Tetteh, 2010).

(Figs. 21a and b) (Gutzmer and Beukes, 1996b). These ferruginous manganese ores form the so-called Western Belt of the manganese field and merge with the ores of the Eastern Belt along both the northern and southern margins of the Maremane dome (Fig. 21a).

The ores are best developed along strike of the lower manganeserich dolomite units of the underlying Campbellrand succession, namely the Fairfield Formation and the Ulco Member of the Reivilo Formation (Figs. 21a and b). There is also a clear relationship between the mineralogical composition of the ores and the distribution of cherty dolomite units in the Campbellrand succession. The siliceous manganese ores and deposits of the Eastern Belt are developed in the immediate vicinity of cherty carbonate units, like the Klipfonteinheuwel Formation, that directly overlies the Fairfield Formation, and the cherty Kamden carbonate-facies iron formation member (Beukes and Gutzmer, 2008) that caps manganiferous dolomite of the Reivilo Formation (Figs. 21a and b). In contrast the non-siliceous ferruginous manganese deposits and ores of the Western Belt are developed above the chert-free basal Ulco Member of the Reivilo Formation (Fig. 21b).
The siliceous ore of the Eastern Belt is normally fine-grained and composed of braunite with minor amounts of partridgeite, hematite, authigenic quartz and recrystallized chert fragments (Gutzmer and Beukes, 1996b). The ores typically contain 46-59 wt\% Mn, 0,9$7,5 \mathrm{wt} \% \mathrm{Fe} 4-10 \mathrm{wt} \% \mathrm{SiO}_{2}$. Two varieties of ferruginous ore are present in the Western Belt, namely fine-grained primary bedded sedimentary diagenetic ore, composed of braunite, partridgeite and hematite, and coarse-grained hydrothermally altered ore, composed of bixbyite intergrown with minor diaspore, ephesite, amesite, braunite and hematite. The ores contain 32-46 wt \% Mn, 2,6$22 \mathrm{wt} \% \mathrm{Fe}$ and 0.2-6.4 wt $\% \mathrm{SiO}_{2}$ (Gutzmer and Beukes, 1996b). Recent supergene minerals are represented by cryptomelane and romanechite in both ore belts (Gutzmer and Beukes, 1996b).

Due to their karstic setting, a characteristic feature of the Postmasburg manganese deposits is their very irregular and discontinuous geometry. This is more so for the siliceous deposits of the Eastern Belt that occur as irregular pods and lenses of braunite in the Wolhaarkop breccia (Fig. 21c). The nature of these deposits is related to their genesis as possible ancient wad-like concentrations 


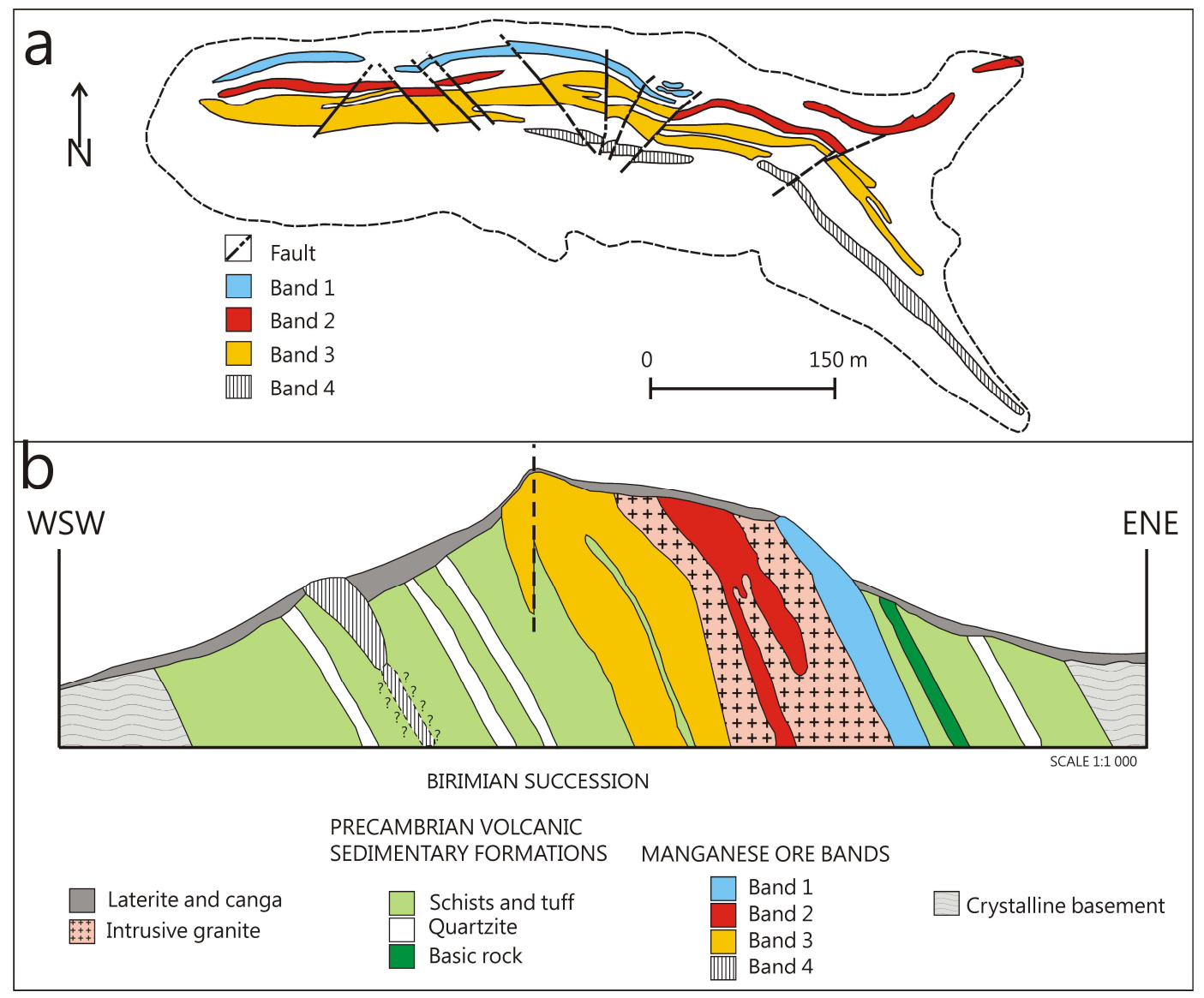

Fig. 19. (a) Geological map and (b) cross section of the Tambao manganese deposit in Burkina Faso (modified after Swindell, 2015). Note the intrusive granite sills.

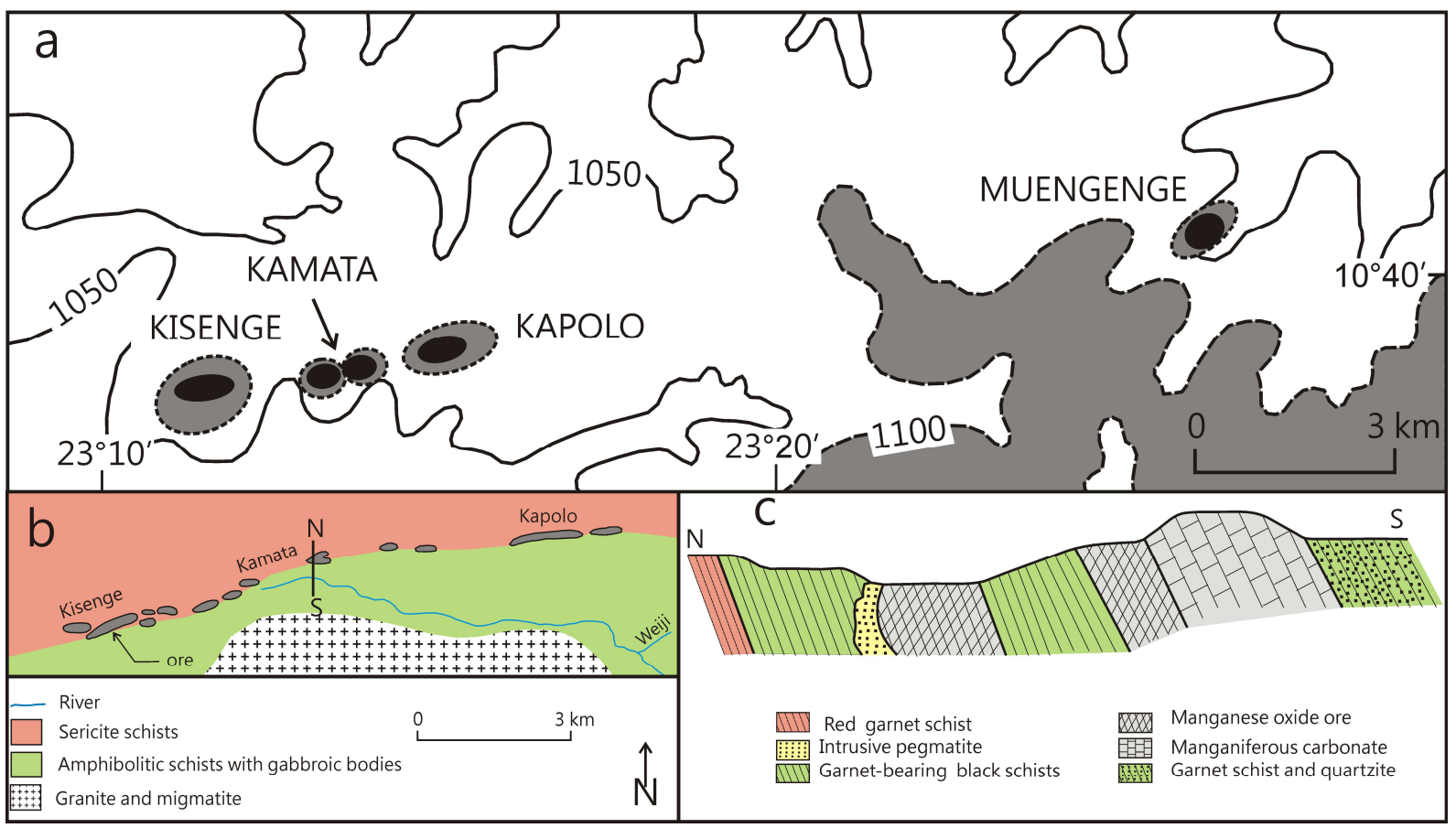

Fig. 20. (a) Topographic map illustrating concentration of supergene ore along an incised old land surface in the Kisenge district of the DRC. (b) Simplified geological map of the Kisenge mine area. (c) Simplified cross section of the Kamata pit of the Kisenge deposit (a-c modified after Doyen, 1973). 


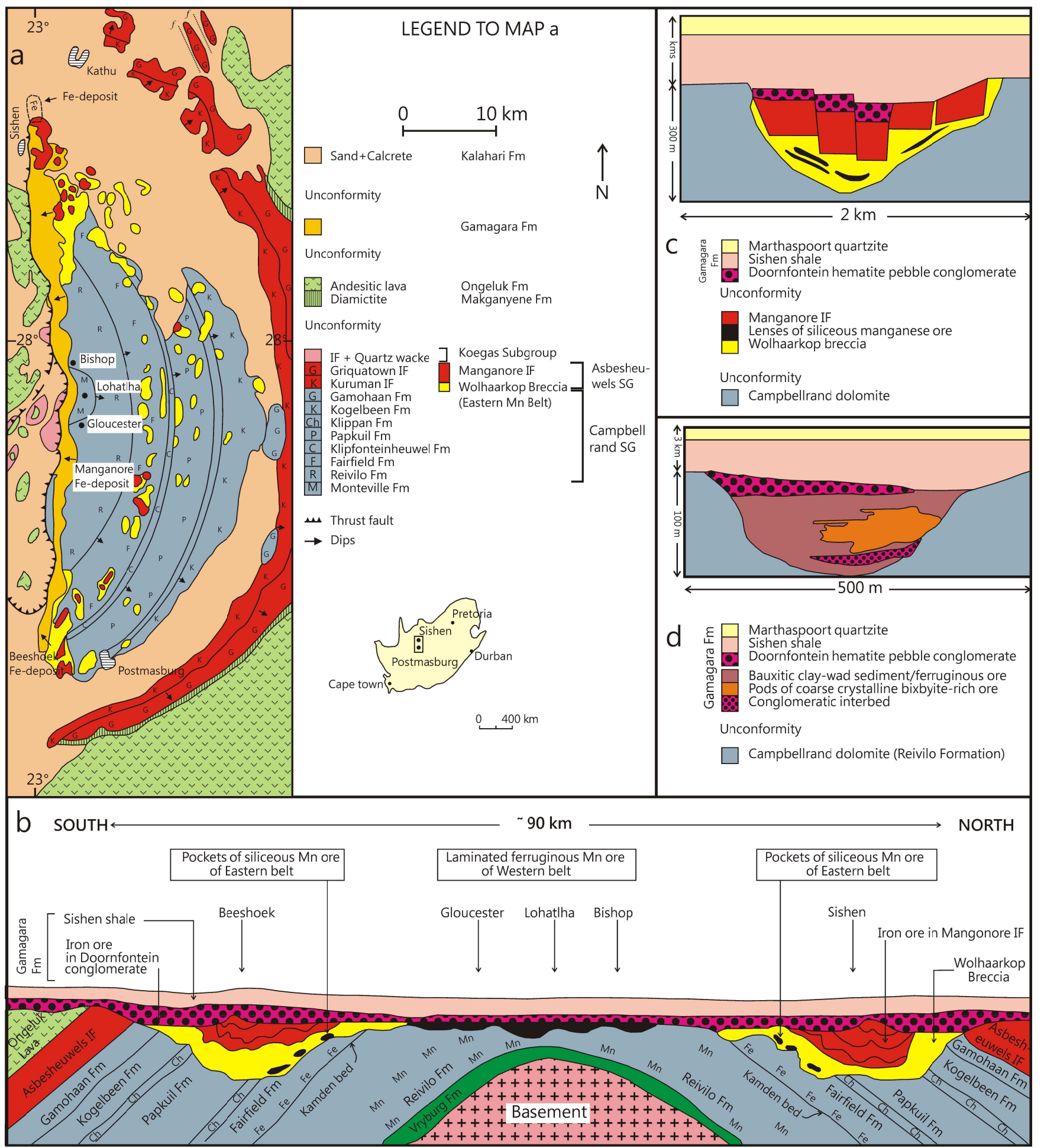

Fig. 21. (a) Geological map of the Maremane dome and (b) schematic $N$-S cross section. (c) Karst-hosted Postmasburg manganese deposits along the Eastern Belt (Manganore area), and (d) Western Belt (Lohatlha area). Note in (d) that Sishen-type high-grade BIF-hosted hematite iron deposits overlie the manganese deposits of the Eastern Belt below the unconformity at the base of the 2.0 Ga Gamagara/ Mapedi red bed succession (Compiled from Gutzmer and Beukes, 1996b; Cairncross et al., 1997).

of Mn-oxyhydroxides associated with internal sediment in collapsed karstic cave systems. The result is that these deposits are made up of a series of high-grade irregular lenses of braunite in siliceous chert breccia (Fig. 21c). Individual lenses or deposits are thus normally very small, never more than a few tens or thousands of tonnes each and in exceptional cases perhaps a few tens of thousands of tonnes.
The ferruginous ore bodies of the Western Belt are less irregular and laterally more continuous and extensive than those of the Eastern Belt due to their apparent original deposition as surficial sediment in small lakes or depressions on the ancient pre-Gamagara karstic land surface (Fig. 21d). This is one reason why these deposits have been mined for a longer period (up to the early 1980s), a relatively large 
scale, in mines such as Glosam, Lohatlha and Bishop in the centre of the Maremane dome (Figs. 21a and b). Hammerbeck and Taljaardt (1976) estimated a resource of $\sim 6 \mathrm{Mt}$ for the whole of the Postmasburg manganese field.

\section{Imini Manganese District, Morocco}

The Imini manganese district is located south of the Central High Atlas Mountains of Morocco some $50 \mathrm{~km}$ to the west-northwest of the town of Quarzazate (Figs. 1 and 22; Table 1). The deposit was discovered in 1918 with production commencing in 1938. The manganese reserves consist of very friable tetravalent oxides, dominantly pyrolusite and manganomelane, mined by underground methods. Output of around 30,000 tonnes per annum consists of high-value fine to ultrafine chemical grade concentrates with $\mathrm{Mn}$ contents of 44.5 to $59.0 \mathrm{wt} \%$ (Swindell, 2015).

The manganese ore is hosted by a 10-20 m thick laterally extensive Middle Cretaceous marine carbonate unit that rests unconformably on Lower Cretaceous and Triassic red beds and folded CambrianOrdovician schists in the foothills of the High Atlas to the north, and Neoproterozoic rhyolite of the Anti-Atlas to the south (Fig. 22 top). The carbonate unit is overlain by a karstified erosional unconformity then Late Cretaceous terrestrial red beds (Fig. 22 middle). It is during this period of uplift and karstification that the Imini manganese deposits formed. The manganese ore minerals occur as a component of internal sediment in one to three zones of stratabound ancient cave

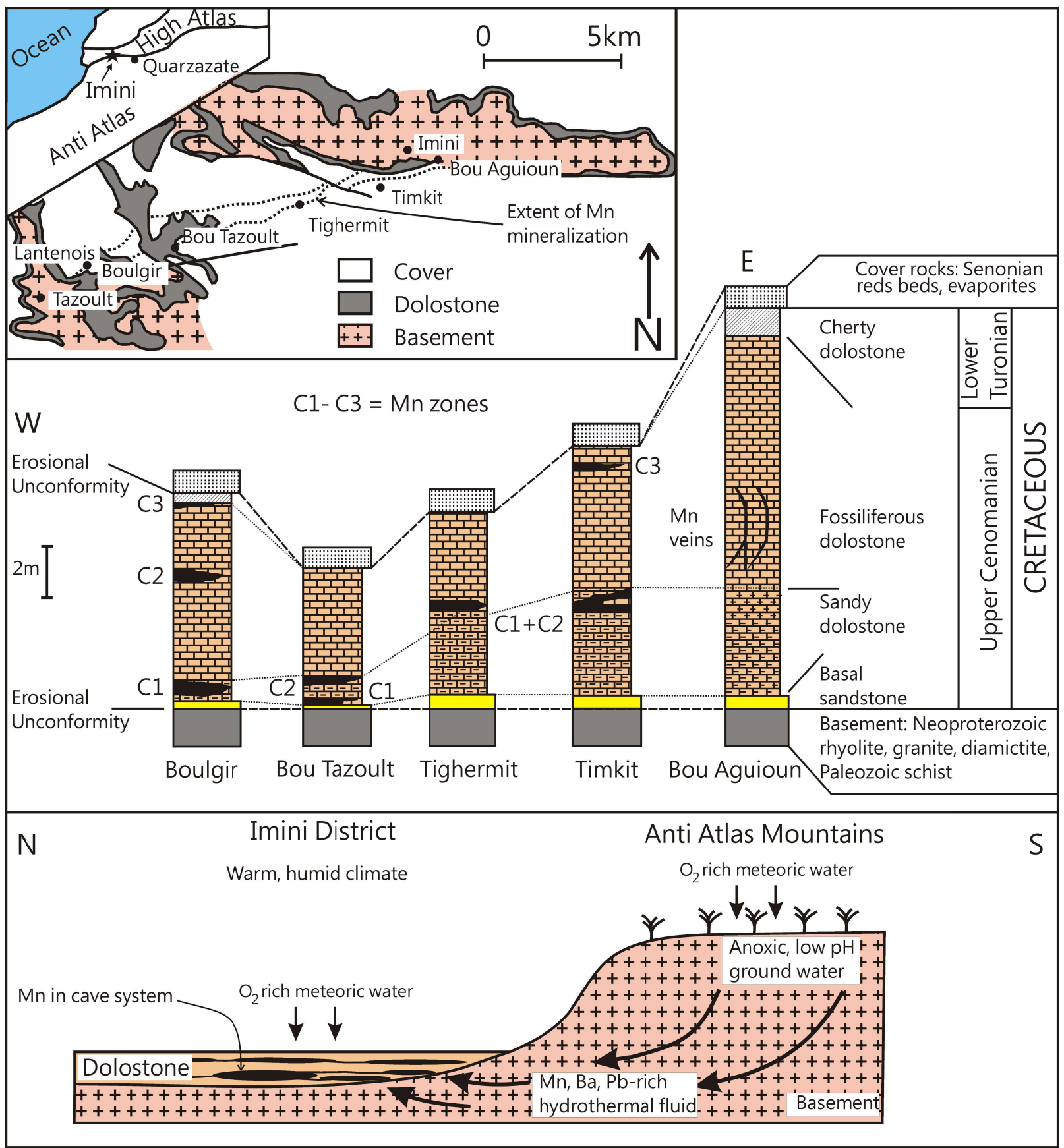

Fig. 22. Simplified geological map of the Imini area in Morocco (top), with stratigraphic setting of cave-hosted manganese deposits in Cretaceous carbonate bed (middle) and genetic model (bottom). Explanation in text (Compiled from Gutzmer et al (2006). 
systems developed in the carbonate bed below the upper karstified erosion surface (Fig. 22 middle). The deposits are confined to a narrow east-northeast-striking belt, approximately $15 \mathrm{~km}$ long and 4001,000 $\mathrm{m}$ wide (Fig. 22 top). Several underground mines are developed along the belt with the Timkit mine, immediately south of Imini, being the major producer (Gutzmer et al., 2006).

According to Gutzmer et al. (2006), two types of manganese ores are present in the internal sediment, namely stratabound manganese ore in the lower part of the dolostone sediment and reworked manganese ore granules and clasts in the upper part. A third variety of manganese ore occurs as a stockwork of veins or as cement to crackle breccia bodies in the carbonate host rock (Fig. 22 middle). This variety of ore is mainly composed of coarse-grained pyrolusite. In contrast, the ores in the internal sediment are composed of poorly consolidated, very fine barium $(\mathrm{Ba})$-lead $(\mathrm{Pb})$-potassium $(\mathrm{K})$-bearing manganomelane and subhorizontal stringers of coarsely crystalline pyrolusite. Kaolinite clay is the main gangue mineral in the internal sediment, combined with variable amounts of quartz, dolomite and illite.

The ores are exceptionally enriched in $\mathrm{Pb}$ (up to $1 \mathrm{wt} \% \mathrm{PbO}$ ) and $\mathrm{Ba}$ (up to $6 \mathrm{wt} \% \mathrm{BaO}$ ) and display very high $\mathrm{Mn} / \mathrm{Fe}$ ratios of between 20 and 330 (Gutzmer et al., 2006). The enrichments in $\mathrm{Pb}$ and $\mathrm{Ba}$ are explained by a model in which the manganese ores formed when warm acidic $\mathrm{Mn}^{2+}$-bearing meteoric water migrated from the elevated regions of the Anti-Atlas region into the exposed carbonate succession (Fig. 22 bottom). Alkali feldspar-rich igneous basement rocks were the source for $\mathrm{Mn}, \mathrm{Pb}$, and $\mathrm{Ba}$. Metals were deposited in a zone of mixing between metal-bearing, reducing meteoric water and oxygenated ground water, resident in a cave system (Fig. 22 bottom), prior to deposition of the overlying Late Cretaceous terrestrial red bed succession (Gutzmer et al., 2006).

\section{Oolitic Tolwe Deposit, South Africa}

The late Palaeoproterozoic Tolwe manganese deposit (also referred to as the Bronkhorstfontein deposit; Gutzmer et al., 2002), is the oldest known pisolitic manganese deposit in the world (Schaefer et al., 2001). It is situated on the farms Bronkhorstfontein, Baaden and Retief, about $15 \mathrm{~km}$ south of Tolwe in the Limpopo Province of South Africa (Fig. 1; Table 1). The deposit is hosted by red beds in the Roodeberg outlier of the Wyllies Poort Formation of the 1.81.96 Ga Palaeoproterozoic Soutpansberg Group (Fig. 23a). Manganese beds are only known to occur in this specific outlier of the Wyllies Poort Formation; they are apparently absent in the main outcrop area of the Soutpansberg Group, located to the east. However, further to the west, in Botswana, the Palapye Group, considered a correlative to the Wyllies Poort Formation (Cheney et al., 1990), contains a very persistent manganese-rich unit (Schaefer et al., 1999) that could be a correlative of the manganese-bearing unit at Tolwe (Gutzmer et al., 2002).

Manganese mineralisation on the farm Bronkhorstfontein was first mentioned by Visser (1953) and mining of the deposit took place intermittently between 1960 and 1995, in both underground roomand-pillar and open cast operations. The mine finally closed down in 1995 , mainly because of high transport costs and low grades. The total remaining resource is estimated to be 10 to $15 \mathrm{Mt}$ of manganese ore (Astrup and Tsikos, 1998) with grades of 30 to $40 \mathrm{wt} \% \mathrm{Mn}$.

The manganese bearing horizons are interbedded with a distinct, ca. $100 \mathrm{~m}$-thick, siltstone and shale-rich unit developed near the top

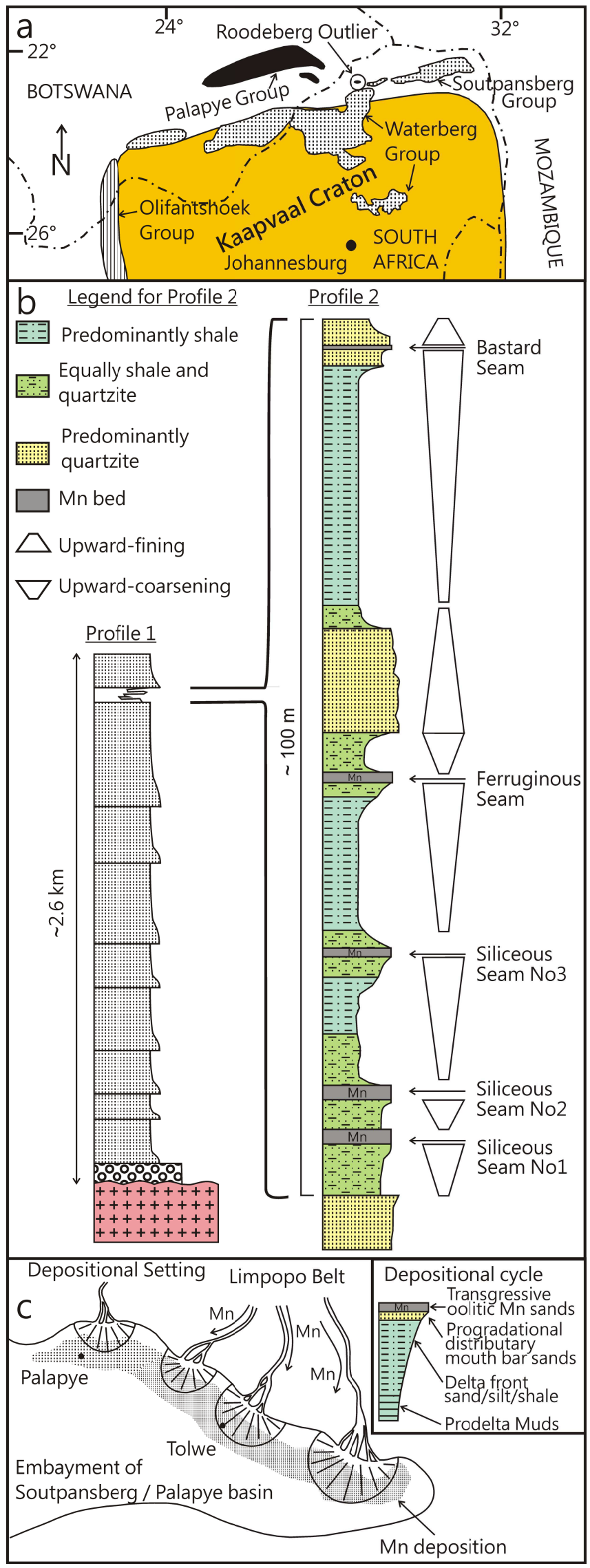

Fig. 23. (a) Geological and (b) stratigraphic setting of the Tolwe oolitic manganese ore beds and (c) proposed depositional setting (Compiled from Gutzmer et al., 2002). 
of the Wyllies Poort Formation as preserved in the Roodeberg outlier (Fig. 23b). This unit, defined as the Manganese Member, contains five laterally continuous beds of manganese ore and manganiferous quartzite that are each in the order of 1-2 m thick (Fig. 23b). The manganese beds cap a sequence of upward coarsening shale, siltstone, and quartzite depositional successions, interpreted as representing prograding delta deposits. The manganese beds are believed to have formed during transgressions on delta plains at times when siliciclastic input was at a minimum (Fig. 23c).

The massively bedded siliceous ore contains up to $41 \mathrm{wt} \% \mathrm{Mn}$ with $\mathrm{Mn} / \mathrm{Fe}$ ratios in the order of 6-10 and $\mathrm{SiO}_{2}$ concentrations of 18-20 wt\% (Gutzmer et al., 2002). The ores are composed of braunite, hematite and quartz, with minor pyrolusite, cryptomelane and chalcedony as products of supergene alteration. The most striking feature of the manganese ores of the Tolwe deposit is the preservation of manganese peloids, oolites and oncolites, mixed in with wellrounded and often manganese-coated quartz grains (Gutzmer et al., 2002). Based on the similarity of the oncolites with modern biogenic analogues, Schaefer et al. (2001) suggested that micro-organisms mediated manganese precipitation. These coated grains indicate that manganese deposition took place in an agitated shallow water environment supporting the model that the ore beds formed during transgressions on abandoned delta plains (Fig. 23c).

\section{Genesis and Palaeoenvironmental Setting of Manganese Deposits}

\section{Primary Sedimentary Deposits}

The sedimentary manganese deposits of Africa provide insight into various aspects of manganese ore formation including their precipitation, diagenesis, basinal setting, the sources of manganese, the supergene alteration and possible relationships to long term continental- to global-scale palaeoenvironmental changes or events in Earth history. With reference to the latter it is important to note that all the major sedimentary manganese deposits of Africa, namely the BIF-hosted KMF and the black shale-hosted deposits of West Africa, Gabon and the DRC, post-date the development of a global oxygenated atmosphere, the so-called Great Oxidation Event (GOE), dated at $\sim 2.35 \mathrm{Ga}$ (Fig. 2). The deposits also post-date earlier periods of major accumulations of iron formations in the Archaean and very early Palaeoproterozoic (Fig. 2). This is perhaps not surprising because manganese is much more soluble than iron and requires higher oxygen levels in water for the transformation of $\mathrm{Mn}$ (II) in solution, to insoluble Mn (III or IV)-oxyhydroxide precipitates than Fe (II) in solutions, requires for precipitation of Fe (III)-oxyhydroxide and the formation of iron formations (Beukes and Gutzmer, 2008). However, there are a number of manganese deposits known in the world, of which the Rooinekke deposit of Africa is one, that precede the GOE (Fig. 2). Interestingly enough these older manganese deposits are all composed of manganese carbonates (Fig. 2) and the question becomes whether they were deposited directly as such from marine or lacustrine water columns, or whether they represent diagenetic products of earlier mixed Mn (IV)-oxyhydroxide and organic carbon precipitates that were transformed to manganese carbonates through a process of microbial manganese respiration (Okita et al., 1998). The same question can be asked for the origin of manganese carbonates in the giant KMF and the large black shale-hosted deposits of Africa.
The answer lies in the carbon isotope composition of the manganese carbonates (rhodochrosite and/or kutnahorite). In all these deposits the manganese carbonates are highly enriched in light carbon isotopes, with $\delta^{13} \mathrm{C}$ values distinctly different to that of normal marine or fresh water (Fig. 24), indicating that abundant, isotopically light organic carbon, became incorporated in them during crystallization. This is typically the result of carbonates being derived from the reduction of original Mn (III-IV)-oxyhydroxide precipitates by manganese reducing bacteria, in the presence of organic matter, under suboxic conditions (Fig. 24). The conclusion is thus that the Mncarbonates in these deposits, including those of the pre-GOE Rooinekke deposit (Fig. 2), are of diagenetic origin and were derived from original Mn-oxyhydroxide precipitates. This has important implications for redox conditions in the depositories of the manganese beds because currently, there is no known mechanism, either inorganic or biogenetic, through which large volumes of Mn-oxyhydroxides can be precipitated, without the presence of at least some free oxygen in the system (Konhauser, 2007). It is also known that rates of Mnoxyhydroxide precipitation are vastly enhanced in the presence of micro-aerophyllic manganese oxidizing bacteria (Emerson et al., 1982). The primary organic matter so produced could then become involved, together with other particulate organic matter, in degradation by manganese respiration (Fig. 24), resulting in the formation of diagenetic Mn-carbonates with highly depleted $\mathrm{C}^{13}$ isotopic compositions (Okita et al., 1988; Maynard, 2010). It would thus appear that prior to the rise of oxygen in the atmosphere, as defined by the GOE at $\sim 2.35 \mathrm{Ga}$, some flux of free oxygen was already available in ocean basins as indicated for example, by the presence of $\delta^{13} \mathrm{C}$-depleted manganese carbonates in the Rooinekke iron formation

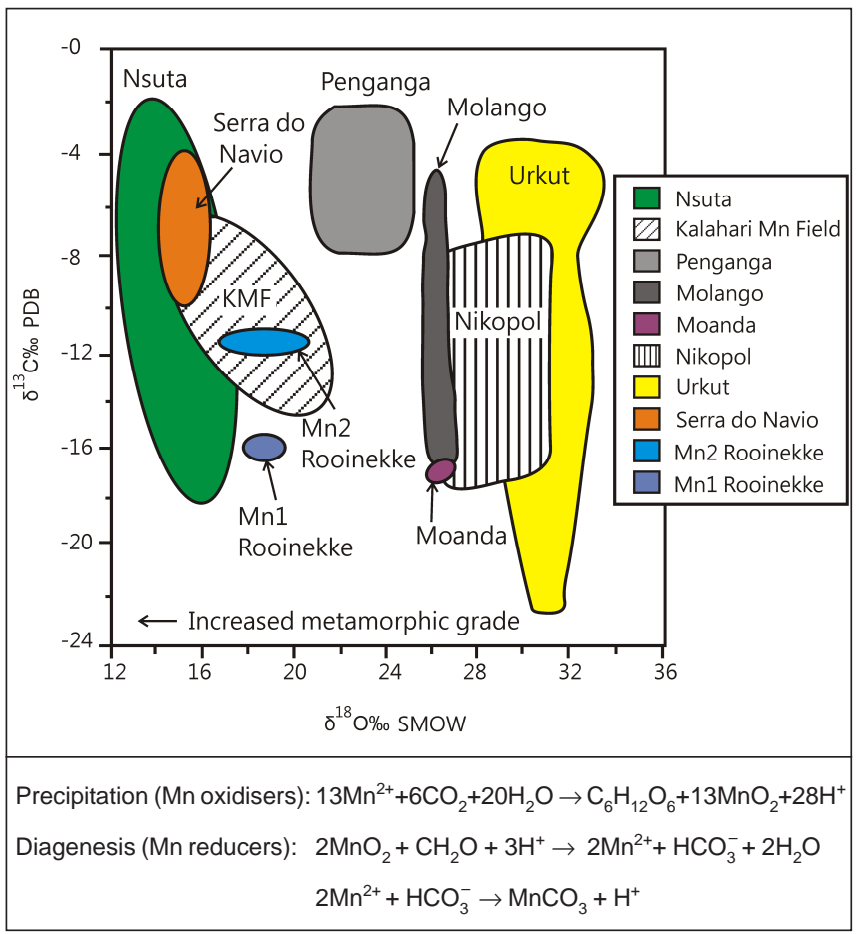

Fig. 24. (a) Comparison of stable isotope composition of manganese carbonates in various carbonate-rich manganese deposits of the world and (b) explanation of the origin of the carbonates through reduction of original manganese oxide precipitates by organic matter (Modified from Chisonga et al., 2012; Gutzmer and Beukes, 2002). 
(Fig. 24); a conclusion supported by studies of other redox sensitive elements such as $\mathrm{Mo}, \mathrm{Cr}$ and $\mathrm{N}$, in pre-GOE sedimentary successions (Wille et al., 2007; Godfrey and Falkowski, 2009; Crowe et al., 2013; Planavsky et al., 2014).

The presence of distinct PAAS-normalized negative cerium (Ce) anomalies in microcrystalline sedimentary braunite-kutnahorite ores of the KMF and Rooinekke manganiferous iron formation, coupled with positive $\mathrm{Ce}$ anomalies in the Nsuta deposits also suggest the presence of oxygenated conditions in the basins (Fig. 25). In addition, the positive Ce anomalies in the Nsuta deposits, support the notion that the carbonates were derived from earlier Mn-oxyhydroxides because it is a well-known fact that in modern oxygenated depositional environments, insoluble Ce (IV) tends to become preferentially adsorbed onto Mn-oxyhydroxide precipitates leaving a negative $\mathrm{Ce}$ anomaly in the ambient water column (Elderfield, 1988). The Tolwe oolitic manganese beds also display positive Ce anomalies (Fig. 25), suggesting adsorption onto Mn-oxyhydroxide precipitates during deposition on flooded delta plains (Fig. 23c).

The nature of the depositional systems and the sources of manganese for the major sedimentary manganese deposits of Africa can be established from facies reconstructions and PAAS-normalized REE data. Unfortunately REE data is only available for a few of these deposits. The KMF and Nsuta deposits and the manganiferous Rooinekke iron formation, all display some enrichment of heavy REE over light REE (Fig. 25), suggesting deposition from a marine water column (Klein and Beukes, 1989; Bau and Dulski, 1996). However, the Rooinekke iron formation and Nsuta manganese carbonate beds also display marked positive europium (Eu) anomalies (Fig. 25) that are normally taken to indicate deposition from an ocean water system that carried a highly diluted component of hydrothermal fluid derived from an original hot $\left(>250^{\circ} \mathrm{C}\right)$ source (Bau and Dulski, 1996). Interestingly, the manganese ores of the KMF typically display at most only very weak positive Eu anomalies (Fig. 25), suggesting that either there was no hydrothermal component present in the water column from which the manganese ores were precipitated, or that fluids came from a cool to moderate temperature $\left(<250^{\circ} \mathrm{C}\right)$ initial hydrothermal source (Bau and Dulski, 1996). However, interfingering of the iron formation and manganese beds of the Hotazel Formation of the KMF (to the west, off the Kaapvaal Craton), with granular jasper, lava and tuffaceous beds (Fig. 4b), strongly suggests deposition in a back-arc basinal setting with hydrothermal fluids derived from a volcanic arc (Cairncross and Beukes, 2013).

The apparent deposition of manganese ore beds in deeper water than associated granular iron formations and jasper in parts of the KMF (Fig. 4b), calls for two distinctly different sedimentary genetic models for BIF-hosted manganese ores. In classical situations, as for example the Otjosondu deposit in Namibia, sedimentation is considered to have taken place from upwelling hydrothermallyenriched ocean water onto a shelf with iron precipitated more distally and deeper relative to manganese, which would have been precipitated closer inshore, in shallower more highly oxygenated environments (Figs. 12b and 26a). In the KMF, the opposite appears to be the case and the best explanation here may be that the manganese was deposited at the distal end of a buoyant hydrothermal plume that spread from an uplifted volcanic terrain into a well circulating oxygenated ocean water column (Fig. 26b).

An important consideration to note when developing depositional models for thick manganese ore beds, whether composed of manganese oxides or carbonates, is that accumulation must have taken
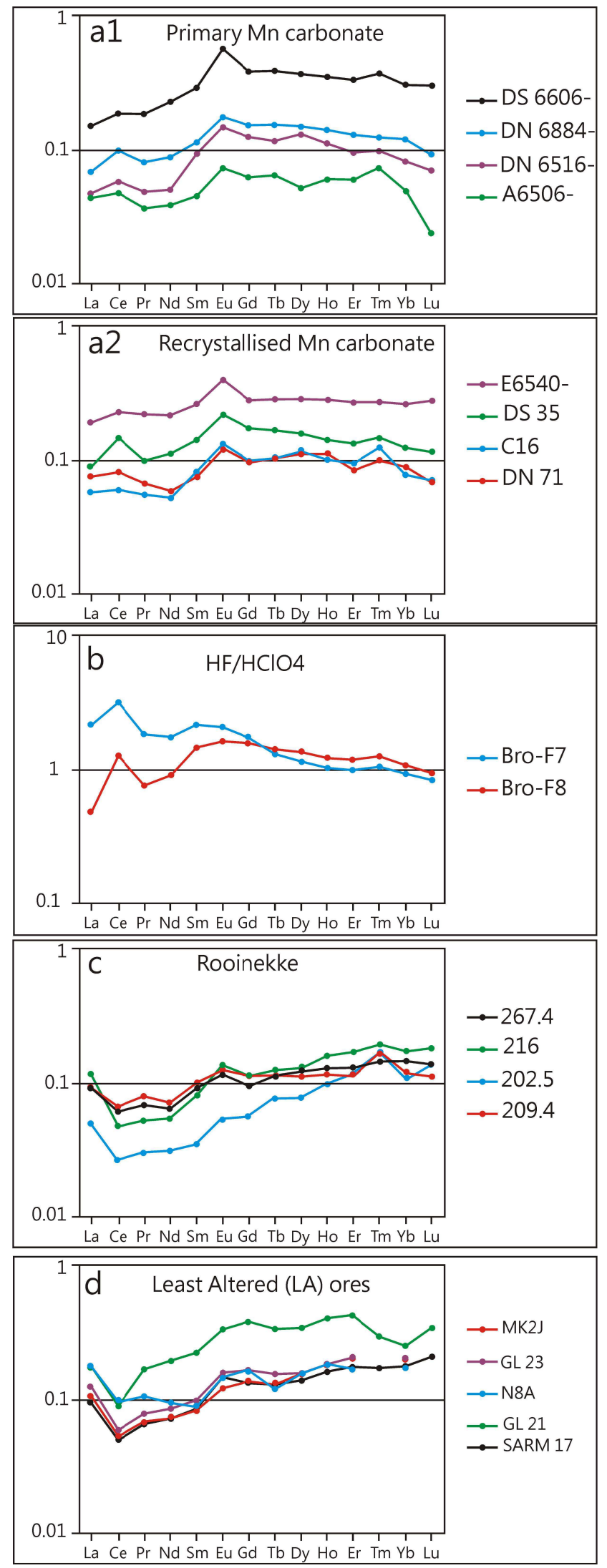

Fig. 25. Examples of PAAS-normalized REE compositions of (a) Nsuta carbonates (from Tetteh, 2010), (b) Tolwe braunitic oolite ore (Gutzmer et al., 2002), (c) Rooinekke manganiferous BIF (from $\mathrm{Nel}$, 2013) and (d) Mamatwan-type braunite-kutnahorite ore of the KMF (from Chetty and Gutzmer, 2012). 


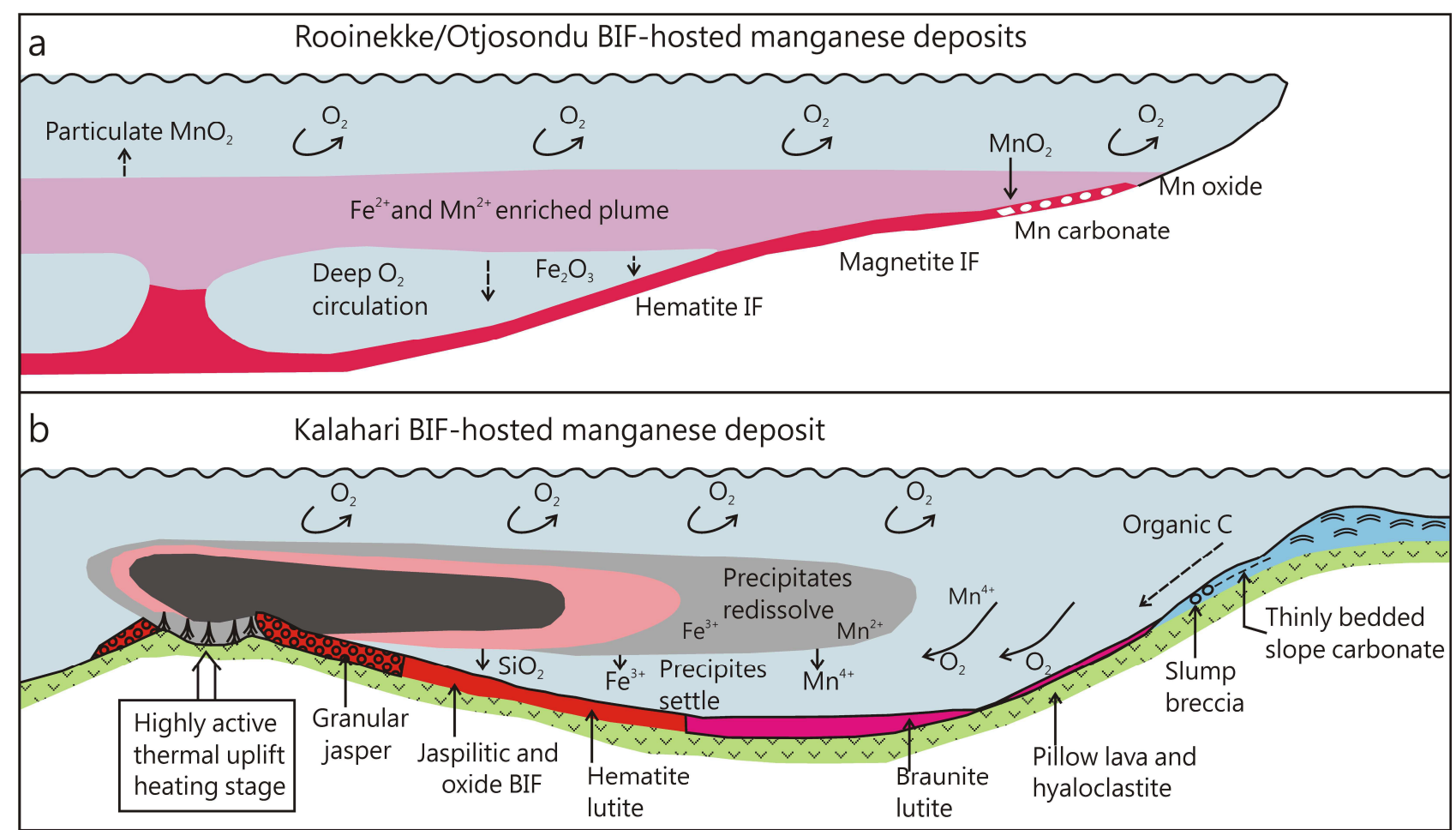

Fig. 26. Contrasting models for manganese deposits in shallow platform settings relative to deeper water settings of associated iron formation as envisaged for Otjosondu and Rooinekke (a)(adapted from Bühnet al., 1992 and Klein and Beukes, 1993) versus manganese deposited in deeper water as in the KMF (b)(modified after Cairncross and Beukes, 2013).

place on at least a micro-oxygenated or intermittently oxygenated basin floor (Calvert and Pedersen, 1996). If the bottom water of the basin was permanently suboxic or strongly reducing, chances are good that Mn-oxyhydroxide precipitates would have dissolved either in the water column above, or along the sediment-water interface, preventing effective accumulation. In agitated very shallow environments, like those in which the oolitic manganese ores of the Tolwe deposit apparently formed, any organic carbon present could have been degraded by aerobic and nitrate respiration, resulting in preservation of primary manganese oxide ores without any diagenetic manganese carbonates present (Fig.27-3). The opposite is probably true for the accumulation of thick manganese carbonate ore beds that characterize the black shale hosted deposits of West Africa and Kisenge. These deposits contain no evidence of agitated water conditions so that deposition probably took place in deeper quiet water, more restricted environments, allowing for sufficient burial of organic matter together with Mn-oxyhydroxides, to allow for development of suboxic pore water conditions below the sedimentwater interface and crystallization of diagenetic manganese carbonates through a process of microbial manganese respiration (Fig. 24). Such a deep water setting is clearly indicated at Nsuta where the manganese ore beds appear distal to deep water turbidites (Fig. 17). This is different to facies relations in the Francevillian succession where manganese carbonates appear to be developed more proximal to pyritic black shales in an upward shallowing succession. The manganese carbonate beds of West Africa and Kisenge are also highly depleted in siliciclastic detritus implying that they formed along maximum flooding surfaces during periods of very rapid rates of sea-level rise (Fig. 28), whilst formation of the Francevillian manganese carbonates took place contemporaneously with an influx of fine siliciclastics (Fig. 27-4). The latter situation could perhaps be compared to that of the modern Black Sea where manganese deposition takes place close inshore at the interface between oxygenated surface waters and anaerobic deep water (Force and Cannon, 1988; Maynard, 2010). Manganese in this situation is mainly derived from continental influx and dissolution from sediment, accumulated in the deeper anoxic bottom waters of the basin (Fig. 27-4). As mentioned earlier, the Birimian manganese carbonate beds were most probably deposited in back-arc basinal settings. Coupled with positive Eu anomalies in the carbonate beds, as observed at Nsuta (Fig. 25), it is postulated that these deposits formed from buoyant hydrothermal plumes in periods of rapid sea-level rise, when siliciclastic input into the basins was at a minimum (Fig. 28).

In conclusion it is perhaps also worth speculating on reasons for the major sedimentary manganese deposits of Africa, namely those of the KMF, Birimian, Francevillian and Kisenge, to have been deposited in the same time interval at $2.2-2.0 \mathrm{Ga}$ (Fig. 2; Table 1). This is the time immediately preceding the main phase of continental collision that resulted in the formation of the supercontinent Columbia, of which the convergent orogenic belts in Africa are referred to as the Eburnian (Zhao et al., 2002; Meert, 2012). It is during these early phases of convergent tectonics that manganese deposition took place in back-arc basins in West Africa along the eastern margin of the Man Craton, a retroarc basin along the western margin of the Kaapvaal Craton, to form the KMF and possibly a back-arc basin along the southern margin of the Archaean core of the Congo Craton, to form the Kisenge deposits (Fig. 28). Closely linked in time, manganese deposition also took place in the Francevillian succession more inland along the northwestern margin of the Congo Craton before it collided with the Sao Francisco Craton (Fig. 28). It is especially clear in the Birimian succession that the manganese deposits formed early on in volcanic-dominated back-arc basins of 


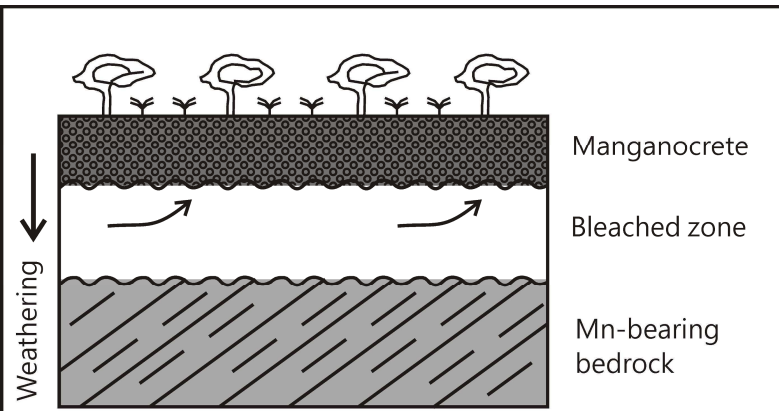

(1) Francevillian supergene

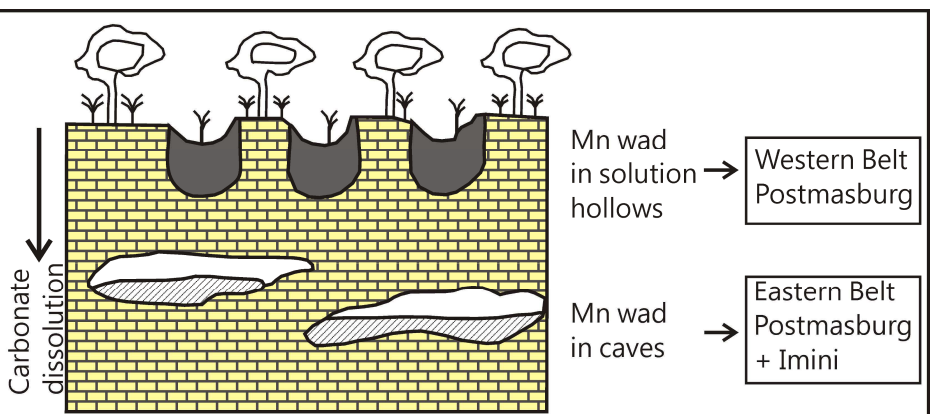

Karst-hosted manganese deposits

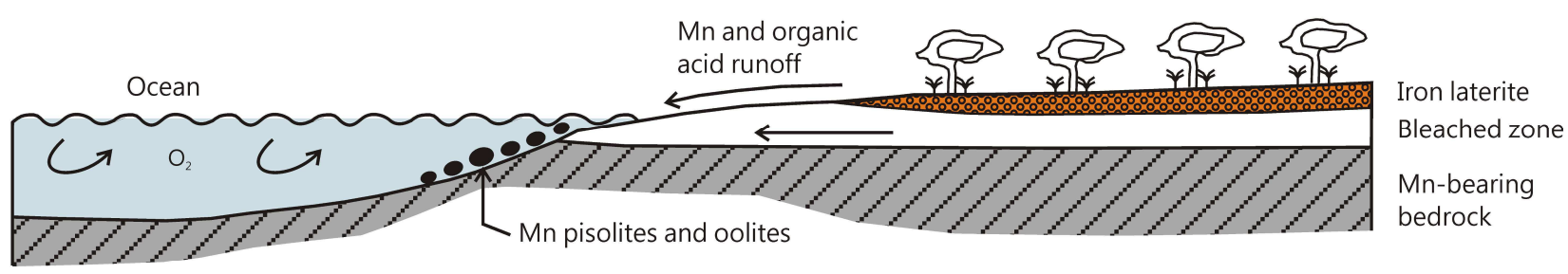

(3) Tolwe pisolitic and oolitic manganese deposit

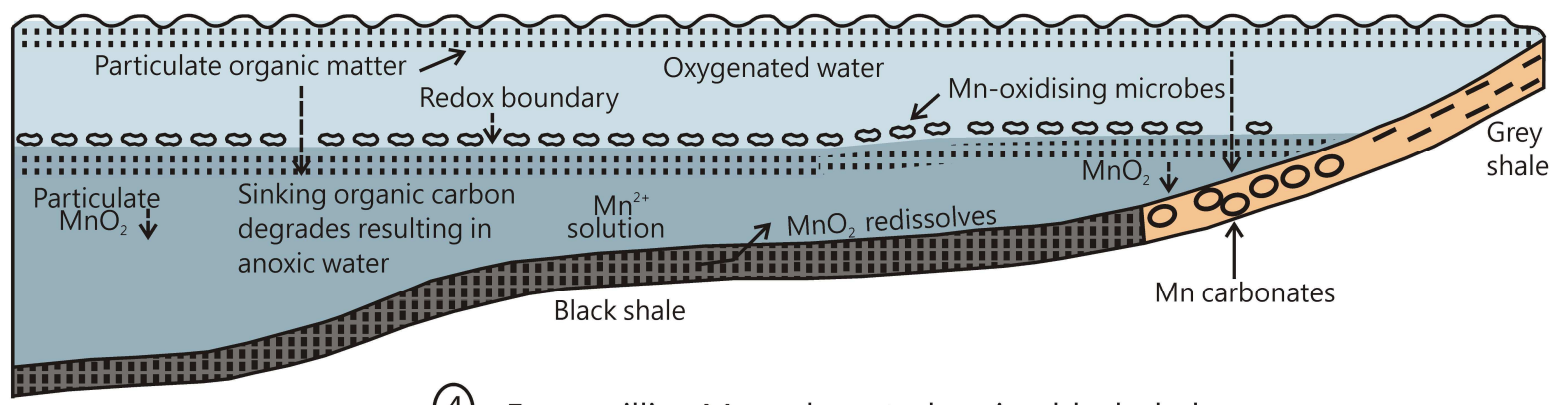

(4) Francevillian Mn carbonate-bearing black shale

Fig. 27. Simple depositional models for (1) Gabonese supergene, (2) Postmasburg karst-hosted, (3) Tolwe oolitic and (4) Francevillian black shale-hosted manganese deposits.

the Lower Birimian, with limited siliciclastic input and prior to deposition of the very thick flysch turbidite succession of the Upper Birimian, in what most probably was a foreland basinal setting. Also important to note is that the deposits formed during periods of rapid sea-level rise (Fig. 28). It has been suggested that the KMF formed in the aftermath of the $2.2 \mathrm{Ga}$ Makganyene Snowball Earth Event (Kirschvink et al., 2000) and one wonders if the other deposits of that time could not also be linked to the same period of glacio-eustatic sea-level rise.

\section{Supergene and Karst-hosted Deposits}

There were two main periods of supergene manganese ore formation in Africa, namely at $\sim 2.0 \mathrm{Ga}$, along the pre-Gamagara/ Mapedi erosional unconformity, and during the Cenozoic in postGondwana times. It is clear from the Cenozoic supergene-enriched manganese ores that they are best developed in the near equatorial, tropical to subtropical terrains of Africa, in close association with deep lateritic weathering profiles. Similarly, palaeomagnetic data indicate that at the time of formation of the $2.0 \mathrm{Ga}$ erosional surface and associated karst-hosted Postmasburg manganese deposits (Fig.2), the Kaapvaal Craton was located near the equator (Evans et al., 2002). It is therefore perhaps not surprising that excellent examples of deep, iron-enriched lateritic weathering profiles are present below the unconformity, manifested best by the development of ancient supergene high-grade BIF-hosted hematite iron ores along it, for example at Rooinekke, in the Hotazel Formation of the KMF and on the Maremane dome between Sishen and Postmasburg (Figs. 4a and 10b; Table 1) (Cairncross and Beukes, 2013). In the KMF, ferruginization of manganese ore beds took place in the lateritic weathering profile (Cairncross and Beukes, 2013), whereas at Rooinekke, it led to formation of jacobsite-hematite manganese ores from manganiferous carbonate precursors in the Rooinekke Iron Formation (Fig. 10b). In addition, highly aluminous shale, comparable to modern bauxitic clays, with associated pisolitic hematite laterites, are present in the immediately overlying lower Doornfontein Member of the Gamagara/Mapedi succession (Gutzmer and Beukes, 1998). Because the development of laterites in the modern day not only requires near equatorial warm, humid climatic conditions with distinct wet and dry seasons, but also lush plant cover, Gutzmer and Beukes 


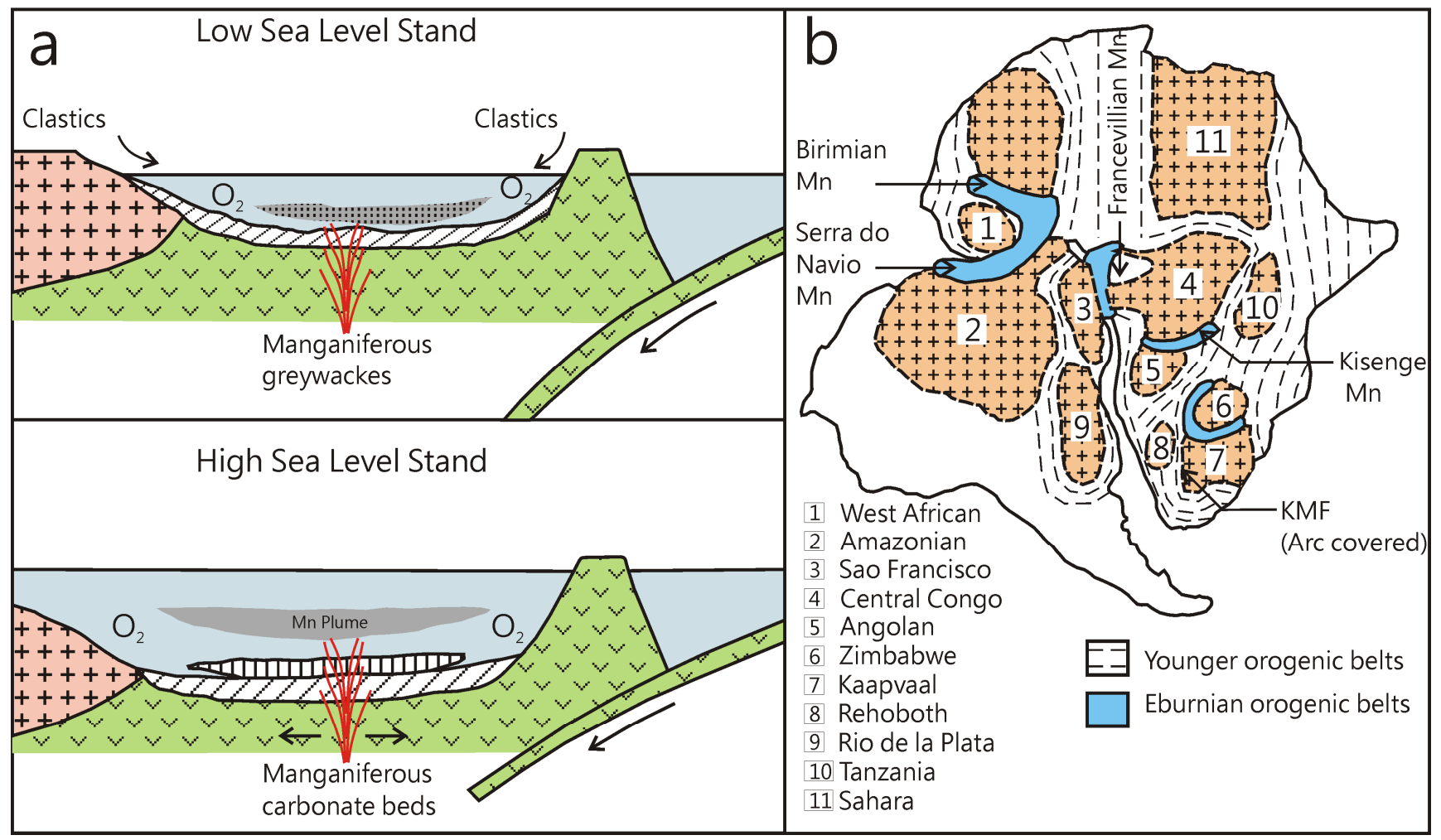

Fig. 28. (a) Depositional models for black shale-hosted manganese carbonate beds in volcanogenic-sedimentary back-arc environments of the Birimian in West Africa, formed as part of the Eburnian orogeny. (b) Present day setting of 2.2-2.1 Ga manganese deposits in Africa closely associated with margins of Archaean cratons that became involved in continental collisions during the late Eburnian at $\sim 2.0$ Ga during amalgamation of the supercontinent Columbia. Note that the Man Craton amalgamated with part of the Amazonian Craton at this time and so did the Northern Congo and Sao Francisco Cratons. However, the relative position of these two amalgamated cratonic blocks in Columbia is unknown, because of a lack of palaeomagnetic data (Reddy and Evans, 2009). The same applies to the position of the Kaapvaal Craton (Reddy and Evans, 2009) that apparently amalgamated with a volcanic arc system along its western margin that is now masked by younger cover rocks $(b)$.

(1998) argue for the presence of abundant microbial life on land at the time of formation of these ancient 2.0 Ga laterites.

The Cenozoic supergene manganese ores of Africa are of two distinct types, namely in situ "oxidation-hydration" deposits and "dissolution-precipitation" manganocrete ("manganese laterite") deposits. In the first type, passive in situ oxidation and hydration of earlier manganese carbonate or mixed Mn (III)-oxide and Mncarbonate ores, took place in a weathering profile. This process led to the formation of the high-grade supergene oxide ores from manganese carbonate protores in West Africa and Kisenge in the DRC (Fig. 17). It also led to the development of supergene enriched manganese ores in the KMF, below the unconformity at the base of the Kalahari Formation (Gutzmer et al. 2012). Ar-Ar dating of K-bearing manganese minerals in these deposits illustrate episodic events of intense supergene alteration. For example at Tambao in Burkina Faso, now in an arid terrain, the last phases of supergene alteration took place at 48-49 Ma and 44.5-47.5 Ma ago (Table 1) (Hénocque et al., 1998). Vasconcelos et al. (1994) finds that the last pervasive oxidation event in West Africa took place some $13 \mathrm{Ma}$ ago. In the KMF, intense supergene alteration took place at around 42, 25, 10 and 5 Ma ago (Gutzmer et al., 2012). It is interesting to note that at Kisenge in the DRC, supergene manganese oxides also formed at 25 and 10 million years ago similar to the KMF (De Putter et al., 2015). However, at Kisenge two main phases of supergene manganese formation also occurred at 3.6 Ma and 2.6 Ma (Table 1) (De Putter et al., 2015). Van
Niekerk et al. (1999) also found that recent supergene manganese nodules, derived from the dissolution of manganiferous Archaean dolomites of the Transvaal Supergroup in South Africa (Mn occurrences no. 48, Fig. 1), also formed in the Middle Miocene at $15 \mathrm{Ma}$ ago. The Middle Miocene and Eocene periods thus appear to be times when climatic conditions were highly suited to the formation of deep weathering profiles in Africa. The fact that the last pervasive deep weathering took place $\sim 13 \mathrm{Ma}$ ago in West Africa, could indicate a general transition to drier and cooler climatic conditions in more recent times in that area (Vasconcelos et al., 1994). However, at Kisenge such conditions must have persisted until as recently as 2.6 Ma, if data from De Putter et al. (2015) is taken into consideration.

The Gabonese manganese deposits are classical examples of mobilized manganocrete deposits. They can be equated with the formation of ferric laterites in the sense that manganese mobilized from manganiferous bedrock in deeper parts of weathering profiles became concentrated near surface in an oxygenated environment (Fig. 27-1). As in the case of ferric laterite formation, it may well be that Mn-carbonates were dissolved by acidic fluids under reducing conditions during wet seasons, with lush plant cover resulting in high concentrations of organic acids in water- soaked soils. Then during dry seasons, with drying and oxygenation of soils, coupled with upward capillary movement of manganese-bearing water from deeper soil or weathering horizons, Mn (IV)-oxyhydroxides precipitated near surface to form manganocrete (Fig. 27-1). 


\section{Conclusion}

Africa holds more than $80 \%$ of the world's known land-based ore resources of manganese metal with some $77 \%$ present in the Kalahari Manganese Field of South Africa (Fig. 3). However, Africa held only $30.5 \%$ of the World's total proven ore reserves of landbased manganese metal during 2014 with the biggest discrepancy represented by proven reserves in the KMF forming only $3.6 \%$ of the total (Fig. 3). This clearly illustrates the need for more detailed exploration drilling, not only in the KMF but also in the rest of Africa. In addition Africa only provided some $41 \%$ of all manganese metal in ores mined in 2014. Here, the KMF in South Africa made the biggest contribution with $26.1 \%$, ahead of China that produced $17.8 \%$ (Fig. 3). With the rapid decline of manganese ore resources in China and their overall low grade, coupled with a large per capita demand for steel in that country, the manganese deposits of Africa should hold even more economic potential for the future than they currently do (Cairncross and Beukes, 2013). However, this potential could only be fully utilized if infrastructure, like railway and harbor facilities, is improved and better transport corridors developed in the areas with large manganese resources. Even in the case of South Africa's KMF, the current harbor and railway capacity is insufficient to provide fully for the demand for export ores. As discussed earlier it is believed that especially Kisenge in the DRC and Tambao in Burkina Faso, hold very large potential for providing good quality ores to export markets, if proper railway and harbor facilities could be constructed. However, Africa's economy would benefit most from the manganese ore resources it holds, if more attention was given to developing downstream utilization of ores, like sintering of carbonate-rich ores, or production of manganese alloys, rather than just exporting raw ore material.

Some $94 \%$ of manganese ore is used in the production of ferroalloys that are in turn consumed in the production of steel. The ferroalloy industry is primarily driven by the cost of its most important input, namely electricity. Most of the globes ferroalloy plants are located close to the final end-point consumers, namely the Iron and Steel producers. This factor has, as a consequence meant that there are very few ferroalloy plants beneficiating Mn ore in Africa, namely a few in South Africa (currently 4 companies), with the possible future construction of a plant in Gabon, which is in turn subject to the expansion of the Poubara hydro-electricity scheme near Franceville. Ferroalloy plants in South Africa are currently at risk given the increasing cost and unreliability of electricity supply. A number of the furnaces have been switched off, or have switched to other products such as Ferro-chrome, where and when suitable. Currently the largest Fe-Mn plant in Gauteng has 3 of its 4 furnaces shut $\mathrm{p}$ ending strategic review by the operating company.

The only significant Mn metal and chemical plant in Africa is also in South Africa, at Nelspruit, but is fraught with complex environmental and cost issues. Future expansion of such plants in Africa is probably unlikely given the competitive character of the Chinese industry, where most producers are now located.

Apart from their economic potential, the manganese deposits of Africa also hold important clues as to the geological history of the world. In particular, the sedimentary Palaeoproterozoic deposits may hold important information about the availability of free oxygen in the world's oceans and atmosphere of that time and possible links to global glacio-eustatic sea-level changes and tectonic events that led to construction of the supercontinent Columbia at $\sim 2.0 \mathrm{Ga}$. In addition the ancient Palaeoproterozoic supergene deposits provide insight into conditions on land, palaeogeographic settings and climatic conditions in that period. Similarly, the large Cenozoic deposits of Africa hold the potential to supply information on development of old land surfaces and climatic conditions in Africa, following the breakup of Gondwana. However, most of the deposits in Africa have been very poorly studied, especially with regards to detailed and modern petrographic, geochemical, isotopic, palaeomagnetic and age dating techniques available. The only exceptions are perhaps the KMF in South Africa and Nsuta in Ghana but even these deposits hold much more scope for detailed basin analyses and stable isotope geochemical studies. Hopefully this review will help stimulate more basic research into the manganese deposits of Africa.

\section{Acknowledgements}

EPWS would like to gratefully acknowledge BHP Billiton, and in particular Michael Emond, for permission to utilize knowledge and information gathered over his 38 years with the company and its predecessors such as Samancor Manganese. Furthermore the following, with whom EPWS worked, and whose contribution through the years to that knowledge was significant, are gratefully acknowledged; Peter Harrison, Solly Van Der Merwe, Matt Gibson, David Payne, Gabriel Kamga, Ricky Arnot, Oscar Van Antwerpen, Pamela Naidoo, Conri Moolman and EP Ferreira. NJB would especially like to acknowledge the contributions made by Jens Gutzmer during collaborative research on manganese deposits under the umbrella of the PPM Research Group with funding support from the University of Johannesburg Central Research Committee, Assmang and Samancor. HW holds a post-doctoral fellowship from the National Research Foundation and NJB acknowledges research funding from the DST-NRF Centre of Excellence for Integrated Mineral and Energy Resource Analysis (CIMERA). We would also like to thank Profs Barry Maynard and Jens Gutzmer for constructive reviews.

\section{References}

Astrup, J.and Tsikos, H. (1998). Manganese. 450-460; In: Mineral Resources of South Africa.Handbook 16, Geological Survey of South Africa, Editors, Wilson M. G. C. and Anhaeusser C.R., $740 \mathrm{p}$.

Baratoux, L., Metelka, V., Naba, S., Jessell, M. W., Grégoire, M., and Ganne, J. (2011). Juvenile Paleoproterozoic crust evolution during the Eburnean orogeny $(<2.2-2.0 \mathrm{Ga})$, western Burkina Faso. Precambrian Research, 191, 18-45.

Bau, M. and Dulski, P. (1996). Distribution of yttrium and rare-earth elements in the Penge and Kuruman iron-formations, Transvaal Supergroup, South Africa. Precambrian Research, 79, 37-55.

Bau, M., Romer, R., Lüders, V. and Beukes, N.J. (1999). Pb, O and C isotopes in silicified Mooidraai dolomite (Transvaal Supergroup, South Africa): Implications for the composition of Paleoproterozoic seawater and 'dating' the increase of oxygen in the Precambrian atmosphere. Earth and Planetary Science Letters, 174, 43-57.

Bekker, A., Karhu, J.A., Eriksson, K. A. and Kaufman, A.J. (2003). A Chemostratigraphy of Paleoproterozoic carbonate successions of the Wyoming Craton: tectonic forcing or biogeochemical change? Precambrian Research, 120, 279-325.

Beukes, N. J., and Gutzmer, J. (2008). Origin and paleoenvironmental significance of major iron formations at the Archaean-Paleo- 
proterozoic boundary. Reviews in Economic Geology, 15, 5-47.

Beukes, N.J. and Smit, C.A. (1987). New evidence for thrust faulting in Griqualand West, South Africa: Implications for stratigraphy and the age of red beds. Transactions of the Geological Society of South Africa, 90, 378-394.

Beukes, N.J., Burger, A.M. and Gutzmer, J. (1995). Fault-controlled hydrothermal alteration of Palaeoproterozoic manganese ore in Wessels mine, Kalahari manganese field. South African Journal of Geology, 98, 430-451.

Beukes, N.J., Vorster, C and Frei, D. (2013). Detrital zircon age constraint of the Makganyene Snowball Earth Event (South Africa) at 2.25-2.22 Ga: The youngest of four Huronian glaciations? Abstracts, GSA Annual Meeting, Denver, USA.

Boardman, L.G. (1941). The Black Rock manganese deposit in the Southeastern Kalahari.Transactions of the Geological Society of South Africa, 44, 51-62.

Bühn B., Stansistreet, I.G. and Okrusch, M. (1992). Late Proterozic Outer Shelf Manganese and Iron Deposits at Otjosondu (Namibia) Related to the Damaran Oceanic Opening. Economic Geology, 87, 1393-1411.

Cairncross, B., Beukes, N.J. and Gutzmer, J., (1997). The manganese adventure: The South African Manganese Fields, Assore, Johannesburg, $250 \mathrm{pp}$.

Cairncross, B. and Beukes, N.J. (2013). The Kalahari Manganese Field. Assore, Johannesburg, 384 pp.

Calvert, S. E. and Pedersen, T. F. (1996). Sedimentary geochemistry of manganese: Implications for the environment of formation of manganiferous black shales. Economic Geology, 91, 36-47.

Cheney, E. S., Barton, J. M. and Brandl, G. (1990). Extent and age of the Soutpansberg sequences of southern Africa. South African Journal of Geology, 93, 664-675.

Chetty, D. and Gutzmer, J. (2008). Quantitative X-ray diffraction as a tool for smelting optimization of Kalahari manganese ores. Proceedings of the Ninth International Congress for Applied Mineralogy, ICAM 2008, The Australian Institute of Mining and Metallurgy, Brisbane, 419-427.

Chetty, D. and Gutzmer, J. (2012). REE redistribution during hydrothermal alteration of ores of the Kalahari Manganese Deposit. Ore Geology Reviews, 47, 126-135.

Chisonga, B.C., Gutzmer, J., Beukes, N.J. and Huizenga, J.M. (2012). Nature and origin of the protolith succession to the Paleoproterozoic Serra do Navio manganese deposit, Amapa Province, Brazil. Ore Geology Reviews, 47, 59-76.

Cornell, D.H., Schütte, S.S. and Eglington, B.L. (1996). The Ongeluk basaltic andesite formation in Griqualand West, South Africa: Submarine alteration in a 2222 Ma Proterozoic sea. Precambrian Research, 79, 101-123.

Corathers, L.A. (2014). Manganese (advance release). U.S. Geological Survey 2012 Minerals Yearbook, U.S. Department of the Interior, 47.1-47.19.

Crowe, S.A., Døssing, L.N., Beukes, N.J., Bau, M., Kruger, S.J., Frei, R. and Canfield, D.E. (2013). Atmospheric oxygenation three billion years ago. Nature, 501, 535-538.

De Putter, T., Ruffet, G., Yans, J. and Mees, F. (2015). The age of supergene manganese deposits in Katanga and its implications for the Neogene evolution of the African Great Lakes Region. Ore Geology Reviews, 71, 350-362.

De Villiers, J. (1960). Manganese deposits of the Union of South Africa. Handbook 2. Geological Survey of South Africa, Pretoria, 280 pages

De Villiers, P.R. (1970). The geology and mineralogy of the Kalahari manganese-field north of Sishen, Cape Province. Memoir of the Geological Survey of South Africa, 59, 84 pages.

Doyen, L. (1973). The manganese ore deposit of Kisenge-Kamata
(Western Katanga). Mineralogical and sedimentological aspects of the primary ore. In: G.C. Amstutz et al. (Eds.), Ores in Sediments (pp. 93-100). Springer, Berlin Heidelberg.

Elderfield, H. (1988). The oceanic chemistry of the rare-earth elements: Philosophical Transactions of the Royal Society of London, A325, 105-126.

Emerson, S., Kalhorn, S., Jacobs, L., Tebo, B. M., Nealson, K. H. and Rosson, R. A. (1982). Environmental oxidation rate of manganese (II): bacterial catalysis. Geochimica et Cosmochimica Acta, 46, 1073-1079.

Evans, D.A.D., Gutzmer, J., Beukes, N.J. and Kirschvink, J.L. (2001). Paleomagnetic constraints on ages of mineralization in the Kalahari manganese field, South Africa. Economic Geology, 96, 621-631.

Evans, D.A.D., Beukes, N.J. and Kirschvink, J.L. (2002). Paleomagnetism of a lateritic paleoweathering horizon and overlying Paleoproterozoic red beds from South Africa: Implications for the Kaapvaal apparent polar wander path and a confirmation of atmospheric oxygen enrichment. Journal of Geophysical Research: Solid Earth, 107(B12), 1978-2012.

Feybesse, J. L., Johan, V., Triboulet, C., Guerrot, C., Mayaga-Mikolo, F., Bouchot, V., and N'Dong, J. E. (1998). The West Central African belt: a model of 2.5-2.0 Ga accretion and two-phase orogenic evolution. Precambrian Research, 87, 161-216.

Force, W.F. and Canon, E.R. (1988). Depositional model for shallowmarine manganese deposits around black shale basins. Economic Geology, 83, 93-117.

Gnos, E., Armbruster, T. and Villa, I.M. (2003). Norrishite, $\left(\mathrm{Mn}_{2} \mathrm{Li}\right) \mathrm{Si}_{4} \mathrm{O}_{10}(\mathrm{O})_{2}$, an oxymica associated with sugilite from the Wessels mine, South Africa: Crystal chemistryand ${ }^{40} \mathrm{Ar}-{ }^{39} \mathrm{Ar}$ dating. American Mineralogist, 88, 189-194.

Godfrey, L.V. and Falkowski, P.G. (2009). The cycling and redox state of nitrogen in the archaean ocean. Nature Geoscience, 2, 725-729.

Gutzmer, J. and Beukes, N.J. (1995) Fault-controlled metasomatic alteration of Earl Proterozoic sedimentary manganese ores in the Kalahari Manganese Field, South Africa. Economic Geology, 90, 823-844.

Gutzmer, J. and Beukes, N.J. (1996a). Mineral paragenesis of the Kalahari Manganese Field, South Africa. Ore Geology Reviews, $11,405-428$.

Gutzmer, J. and Beukes, N.J. (1996b). Karst-hosted fresh water Palaeoproterozoic manganese deposits, Postmasburg, South Africa. Economic Geology, 91, 1435-1454.

Gutzmer, J. and Beukes, N.J. (1997). Effects of mass transfer, compaction and secondary porosity on hydrothermal upgrading of Paleoproterozoic sedimentary manganese ore in the Kalahari manganese field, South Africa. Mineralium Deposita, 32, 250256.

Gutzmer, J. and Beukes, N.J. (1998). Earliest laterites and possible evidence for terrestrial vegetation in the Early Proterozoic. Geology, 26, 263-266.

Gutzmer, J. and Beukes, N.J. (2002). Origin of manganese and iron ores at Rooinekke, Northern Cape Province. Final Project Report (unpubl.), Paleoproterozoic Mineralization Research Group, University of Johannesburg, $73 \mathrm{pp}$.

Gutzmer, J., Schaefer, M.O. and Beukes, N.J. (2002). Red bed-hosted oncolitic manganese ore of the Paleoproterozoic Soutpansberg Group, Bronkhorstfontein, South Africa, Economic Geology, 97, 1023-1039.

Gutzmer, J., Beukes, N.J., Rhalmi, M. and Mukhopadhyay, J. (2006). Cretaceous karstic cave-fill manganese-lead-barium deposits of Imini, Morocco, Economic Geology, 101, 385-405.

Gutzmer, J., Du Plooy, A.P. and Beukes, N.J. (2012). Timing of 
supergene enrichment of low-grade manganese ores in the Kalahari manganese field, South Africa. Ore Geology Reviews, 47, 136-153.

Hammerbeck, E.C.I. and Taljaardt, J.J. (1976). Manganese. 167-172. In: Coetzee, C.B. (Ed.). Mineral resources of the Republic of South Africa. Handbook 7, Geological Survey of South Africa, $478 \mathrm{pp}$.

Hénocque, O., Ruffet, G., Colin, F. and Féraud, G. (1998). ${ }^{40} \mathrm{Ar} /{ }^{39} \mathrm{Ar}$ dating of West African lateritic cryptomelanes. Geochimica et Cosmochimica Acta, 62, 2739-2756.

Hoffman, P. F., and Schrag, D. P. (2000). Snowball earth. Scientific American, 282, 68-75.

Holland, H. D., and Beukes, N. J. (1990). A paleoweathering profile from Griqualand West, South Africa: evidence for a dramatic rise in atmospheric oxygen between 2.2 and 1.9 BYBP. American Journal of Science, 290, 1-34.

Johnson, J. E., Webb, S. M., Thomas, K., Ono, S., Kirschvink, J. L., and Fischer, W. W. (2013). Manganese-oxidizing photosynthesis before the rise of cyanobacteria. Proceedings of the National Academy of Sciences, 110, 11238-11243.

Kirschvink, J.L., Gaidos, E.J., Bertani, L.E., Beukes, N.J., Gutzmer, J., Maepa, N. and Steinberger, R.E. (2000). Paleoproterozoic Snowball Earth: Extreme Climatic and Geochemical Global Change and its Biological Consequences. Proceedings National Academy of Science (PNAS), 97, 1400-1405.

Klein, C. and Beukes, N.J. (1998). Geochemistry and sedimentology of a facies transition from limestone to iron-formation deposition in the early Proterozoic Transvaal Supergroup, Griqualand West, South Africa. Economic Geology, 84, 1733-1774.

Klein, C. and Beukes, N.J. (1993). Sedimentology and geochemistry of glaciogenic Late Proterozoic Rapitan iron formation in Canada. Economic Geology, 88, 542565.

Kleyenstüber, A.S.E. (1984). The mineralogy of the manganesebearing Hotazel Formation, of the Proterozoic Transvaal sequence in GriqualandWest, South Africa. Transactions of the Geological Society of South Africa, 87, 257-272.

Konhauser, K. O. (2008). Introduction to geomicrobiology. John Wiley \& Sons, $425 \mathrm{pp}$.

Kunzman, M., Gutzmer, J., Beukes, N.J. and Halverson, G.P. (2014). Depositional environment and lithostratigraphy of the Paleoproterozoic Mooidraai Formation, Kalahari Manganese Field, South Africa. South African Journal of Geology, 117, 173192.

Leclerc, J. and Weber, F. (1980). Geology and genesis of the Moanda manganese deposits, Republic of Gabon, In; Varentsov, IM and Graselly G, (eds); Geochemistry of Manganese, v2 , 89-109.

Macdonald, F. A., Strauss, J. V., Rose, C. V., Dudás, F. Õ.and Schrag, D. P. (2010). Stratigraphy of the Port Nolloth Group of Namibia and South Africa and implications for the age of Neoproterozoic iron formations. American Journal of Science, 310, 862-888.

Maynard, J.B. (2010). The chemistry of manganese ores through time: A signal of increasing diversity of Earth-surface environments. Economic Geology, 105, 535-552.

Meert, J. G. (2012). What's in a name? The Columbia (Paleopangaea/ Nuna) supercontinent. Gondwana Research, 21, 987-993.

Melcher, F. (1995). Genesis of chemical sediments in Birimian greenstone belts: evidence from gondites and related manganesebearing rocks from northern Ghana. Mineralogical Magazine, 59, 229-252.

Moore, J.M., Polteau, S., Armstrong, R.A., Corfu, F. and Tsikos, H. (2012). The age and correlation of the Postmasburg Group, southern Africa: Constraints from detrital zircon grains. Journal of African Earth Sciences, 64, 9-19.

Mücke, A., Dzigbodi-Adjimah, K. and Annor, A. (1999). Mineralogy, petrography, geochemistry and genesis of the Paleoproterozoic Birimian manganese-formation of Nsuta/Ghana. Mineralium Deposita, 34, 297-311.

Nel, B. P. (2013). Pertrography and geochemistry of iron formations of the Paleoproterozoic Koegas Subgroup, Transvaal Supergroup, Griqualand West, South Africa. MSc thesis (Unpublished), University of Johannesburg, $133 \mathrm{pp}$.

Nel, C.J., Beukes, N.J. and De Villiers, J.P.R. (1986). The Mamatwan manganese mine of the Kalahari manganese field. In: Anhaeusser, C.R. and Maske, S. (eds.). Mineral Deposits of Southern Africa. Geological Society of South Africa, Johannesburg, 963-978.

Nyame, F. K. (1998). Mineralogy, geochemistry, and genesis of the Nsuta manganese deposit. Unpublished PhD dissertation, Okayama University.

Nyame, F. (2001). Petrological significance of manganese carbonate inclusions in spessartine garnet and relation to the stability of spessartine in metamorphosed manganese-rich rocks. Contributions to Mineralogy and Petrology, 141, 733-746.

Nyame, F. K. (2008). Petrography and geochemistry of intraclastic manganese-carbonates from the $2.2 \mathrm{Ga}$ Nsuta deposit of Ghana: Significance for manganese sedimentation in the Palaeoproterozoic of West Africa. Journal of African Earth Sciences, 50, 133-147.

Nyame, F.K., Kase, K. and Yamamoto, M. (1998). Spessartine garnets in a manganiferous carbonate formation from Nsuta, Ghana. Resource Geology, 48, 13-22.

Nyame, F.K., Beukes, N.J., Kase, K. and Yamamoto, M. (2003). Compositional variations in manganese carbonate micronodules from the Lower Proterozoic Nsuta deposit, Ghana: product of authigenic precipitation or post-formational diagenesis?. Sedimentary Geology, 154, 159-175.

Okita, P. M., Maynard, J. B., Spiker, E. C. and Force, E. R. (1988). Isotopic evidence for organic matter oxidation by manganese reduction in the formation of stratiform manganese carbonate ore. Geochimica et Cosmochimica Acta, 52, 2679-2685.

Perseil, E. A. and Grandin, G. (1978). Evolution minéralogique du manganèse dans trois gisements d'Afrique de l'Ouest: Mokta, Tambao, Nsuta. Mineralium Deposita, 13, 295-311.

Petters, S. W. (1991). Regional geology of Africa. Lecture Notes in Earth Sciences, Berlin, Springer Verlag, 40pp.

Reddy, S. M. and Evans, D. A. D. (2009). Palaeoproterozoic supercontinents and global evolution: correlations from core to atmosphere. Geological Society of London, Special Publication, $323,1-26$.

Planavsky, N.J., Asael, D., Hofmann, A., Reinhard, C.T., Lalonde, S.V., Knudsen, A., Wang, X., Ossa Ossa, F., Pecoits, E., Smith, A.J.B., Beukes, N.J., Bekker, A., Johnson, T.M., Konhauser, K.O., Lyons, T.W. and Rouxel, O.J., (2014). Evidence for oxygenic photosynthesis half a billion years before the Great Oxidation Event. Nature Geoscience, 7, 283-286.

Rogers, A.W. (1906). Geological survey of parts of Bechuanaland and Griqualand West. Annual Report of the Geological Commission of the Cape of Good Hope, 7-86.

Schaefer, M., Gutzmer, J. and Beukes, N.J. (1999). Stratiform manganese mineralisation in the Palapye Group, East-Central Botswana. In: Stanley et al., (eds). Mineral Deposits: Processes to Processing; Balkema, Rotterdam, 1237-1240.

Schaefer, M. O., Gutzmer, J. and Beukes, N. J. (2001). Late Paleoproterozoic Mn-rich oncoids: Earliest evidence for microbially mediated Mn precipitation. Geology, 29, 835-838.

Schneiderhan, E.A., Gutzmer, J., Strauss, H., Mezger, K. and Beukes, N.J., (2006). The chemostratigraphy of a Paleoproterozoic MnBIF succession - the Voëlwater Subgroup of the Transvaal Supergroup in Griqualand West, South Africa. South African 
Journal of Geology, 109, 63-80.

Service, H. (1943). The Geology of the Nsuta Manganese Ore Deposits. Gold Coast Geological Survey Memoir, 5, 32 pp.

Swindell, E.P.W. (2015). Manganese deposits of Africa - A short review. Internal Report (unpublished), Ed Swindell Consulting Geologist, Krugersdorp, South Africa, 94 pp. https:// sites.google.com/siteledswindellconsultinggeologist/.

Tebo, B. M., Nealson, K. H., Emerson, S. and Jacobs, L. (1984). Microbial mediation of $\mathrm{Mn}$ (II) and Co (II) precipitation at the $\mathrm{O}_{2} / \mathrm{H}_{2} \mathrm{~S}$ interfaces in two anoxic fjords. Limnology and Oceanography, 29, 1247-1258.

Tetteh, G.M. (2010). Geology and mineralization of the Paleoproterozoic Nsuta manganese deposit in the Birimian of Ghana. PhD thesis (unpublished), University of Ghana, Legon, $186 \mathrm{pp}$.

Tsikos, H. and Moore, J.M. (1997). Petrography and geochemistry of the Paleoproterozoic Hotazel iron-manganese formation, Kalahari manganese field, South Africa: Implications for Precambrian manganese metallogenesis. Economic Geology, 92, 87-97.

Tsikos, H. and Moore, J.M. (1998). The Kalahari manganese field: An enigmatic association of iron and manganese. South African Journal of Geology, 101, 287-290.

Tsikos, H., Moore, J.M. and Harris, C. (2001). Geochemistry of the Paleoproterozoic Mooidraai Formation: Fe-rich limestone as endmember of iron formation deposition, Kalahari Mn Field, Transvaal Supergroup, South Africa. Journal of African Earth Sciences, 32, 19-27.

Tsikos, H., Beukes, N.J., Moore, J.M. and Harris, C., (2003). Deposition, diagenesis and secondary enrichment of metals in the Paleoproterozoic Hotazel iron formation, Kalahari manganese field, South Africa. Economic Geology, 98, 1149-1462.

Van Bart, A, (2001). Structure, stratigraphy and sedimentology of the Paleoproterozoic Nsuta Manganese Deposit, Ghana. M.Sc. thesis (unpublished), Rand Afrikaans University, Johannesburg, $110 \mathrm{pp}$.

Varentsov, I.M. (1964). Sedimentary manganese ores. Elsevier, Amsterdam, 119 pp.

Vasconcelos, P.M., Brimhall, G.H., Becker, T.H. and Renne, P.R. (1994). ${ }^{40} \mathrm{Ar}^{39} \mathrm{Ar}$ analysis of supergene jarosite and alunite:
Implications to the paleoweathering history of the western USA and West Africa, Geochimica et Cosmochimica Acta, 58, 401420.

Van Niekerk, H.S., Gutzmer, J., Beukes, N.J., Phillips, D. and Kiviets, G.B. (1999). $\mathrm{An}^{40} \mathrm{Ar}^{39} \mathrm{Ar}$ age of supergene K-Mn oxyhydroxides in a post-Gondwana soil profile on the Highveld of South Africa. South African Journal of Science, 95, 450-454.

Van Schalkwyk, J. F.and Beukes, N. J. (1986).The Sishen iron ore deposit, Griqualand West, 931-956. In: Anhaeusser, C.R. and Maske, S. (Eds). Mineral Deposits of Southern Africa, Vol. I and II, Geol. Soc. S. Afr., Johannesburg, 2335 pp.

Vasconcelos, P. M., Renne, P. R., Brimhall, G. H. and Becker, T. A. (1994). Direct dating of weathering phenomena by ${ }^{40} \mathrm{Ar}^{39} \mathrm{Ar}$ and $\mathrm{K}$-Ar analysis of supergene K-Mn oxides. Geochimica et Cosmochimica Acta, 58, 1635-1665.

Visser, H.N. (1953). The geology of the Koedoesrand area. Explanation of map sheet 36, Geological Surveyof South Africa, Pretoria.

Visser, D. J. L. (1954). Deposits of manganese ore on Rooinekke and neighbouring farms, District Hay. Transactions of the Geological Society of South Africa, 57, 61-75.

Weber, F. (1973). Genesis and Supergene evolution of Precambrian sedimentary manganese deposit at Moanda (Gabon), UNESCO, Genesis of Precambrian Iron and Manganese deposits. Proceedings Kiev Symposium, Earth Sciences, 9, 307-322.

Weber, F. (1997). Evolution of lateritic manganese deposits. In: Soils and Sediments (pp. 97-124). Springer, Berlin Heidelberg.

Wiggering, H. and Beukes, N. J. (1990). Petrography and geochemistry of a 2000-2200-Ma-old hematitic paleo-alteration profile on Ongeluk basalt of the Transvaal Supergroup, Griqualand West, South Africa. Precambrian Research, 46, 241-258.

Wille, M., Kramers, T.F., Beukes, N.J., Schroder, S., Meisel, T.L., Lacassie, J.P. and Voegelin, A.D. (2007). Evidence for a gradual rise of oxygen between 2.6 and $2.5 \mathrm{Ga}$ from Mo isotopes and RePGE signatures in shales. Geochimica et Cosmochimica Acta, $71,2417-2435$.

Zhao, G., Cawood, P. A., Wilde, S. A. and Sun, M. (2002). Review of global 2.1-1.8 Ga orogens: Implications for a pre-Rodinia supercontinent. Earth-Science Reviews, 59, 125-162.

\section{GLOSSARY}

Mineral formulae: Manganese (Mn) deposits of Africa

\begin{tabular}{|c|c|c|c|}
\hline Hematite & $\mathrm{Fe}_{2} \mathrm{O}_{3}$ & Rhodonite & $(\mathrm{Mn}, \mathrm{Fe}) \mathrm{SiO}_{3}$ \\
\hline Specularite & $\mathrm{Fe}_{2} \mathrm{O}_{3}$ & Manganite & $\mathrm{MnO}(\mathrm{OH})$ \\
\hline Kutnahorite & $\mathrm{CaMn}\left(\mathrm{CO}_{3}\right)_{2}$ & Groutite & $\mathrm{a}-\mathrm{MnO}(\mathrm{OH})$ \\
\hline Braunite & $\mathrm{Mn}^{2+} \mathrm{Mn}^{3+}{ }_{6} \mathrm{SiO}_{12}$ & Nsutite & $\mathrm{Mn}^{2+}{ }_{x} \mathrm{Mn}^{4+}{ }_{1-x} \mathrm{O}_{2-2 \mathrm{x}}(\mathrm{OH})_{2 \mathrm{x}}$ \\
\hline Jacobsite & $\mathrm{Mn}^{2+} \mathrm{Fe}^{3+} \mathrm{O}_{4}$ & Lithiophorite & $\mathrm{LiMn}^{4+} \mathrm{O}_{2}(\mathrm{OH})_{2}$ \\
\hline Manganese calcite & $(\mathrm{Ca}, \mathrm{Mn}) \mathrm{CO}_{3}^{4}$ & Goethite & $\mathrm{a}-\mathrm{Fe}^{3+} \mathrm{O}(\mathrm{OH})$ \\
\hline Hausmannite & $\mathrm{Mn}^{2+} \mathrm{Mn}^{3+} \mathrm{O}_{4}$ & Spessartine garnet & $\mathrm{Mn}_{3} \mathrm{Al}_{2}(\mathrm{Si}, \mathrm{Al})_{3} \mathrm{O}_{12}$ \\
\hline Bixbyite & $\left(\mathrm{Mn}^{3+}, \mathrm{Fe}^{3+}\right)_{2} \mathrm{O}_{3}$ & Sericite & $\mathrm{K}_{2} \mathrm{Al}_{6} \mathrm{Si}_{6} \mathrm{O}_{20}(\mathrm{OH})_{4}$ \\
\hline Braunite II & $\left.\mathrm{Ca}\left(\mathrm{Mn}^{3+} \mathrm{Fe}^{3+}\right)\right)_{14} \mathrm{SiO}_{24}$ & Manganosite & $\mathrm{MnO}$ \\
\hline Cryptomelane & $\mathrm{K}\left(\mathrm{Mn}^{4+}, \mathrm{Mn}^{2+}\right)_{8} \mathrm{O}_{16}$ & Tephroite & $\mathrm{Mn}_{2} \mathrm{SiO}_{4}$ \\
\hline Manganomelane & (group name for a variety of & Partridgeite & $\mathrm{a}-\mathrm{Mn}_{2} \mathrm{O}_{3}$ \\
\hline & $\mathrm{Mn}^{4+}$ oxide minerals) & Diaspore & $\mathrm{AlO}(\mathrm{OH})$ \\
\hline Pyrolusite & $\mathrm{MnO}_{2}$ & Ephesite & $\mathrm{NaLiAl}_{2}\left(\mathrm{Al}_{2} \mathrm{Si}_{2}\right) \mathrm{O}_{10}(\mathrm{OH})_{2}$ \\
\hline Quartz & $\mathrm{SiO}_{2}$ & Amesite & $(\mathrm{Mg}, \mathrm{Fe})_{2} \mathrm{Al}_{2} \mathrm{SiO}_{5}(\mathrm{OH})_{4}$ \\
\hline Barite & $\mathrm{BaSO}_{4}$ & Romanechite & $\left(\mathrm{Ba}, \mathrm{H}_{2} \mathrm{O}\right)\left(\mathrm{Mn}^{3+}, \mathrm{Mn}^{4+}\right)_{5} \mathrm{O}_{10}$ \\
\hline Siderite & $\mathrm{FeCO}_{3}$ & Dolomite & $\mathrm{CaMg}\left(\mathrm{CO}_{3}\right)_{2}$ \\
\hline Rhodochrosite & $\mathrm{MnCO}_{3}$ & Illite & $\mathrm{K}_{\mathrm{x}} \mathrm{Al}_{4}\left(\mathrm{Si}_{8-\mathrm{x}}, \mathrm{Al}_{\mathrm{x}}\right) \mathrm{O}_{20}(\mathrm{OH})_{4}$ \\
\hline Ankerite & $\mathrm{CaFe}\left(\mathrm{CO}_{3}\right)_{2}$ & Chalcedony & $\mathrm{SiO}_{2}$ \\
\hline
\end{tabular}




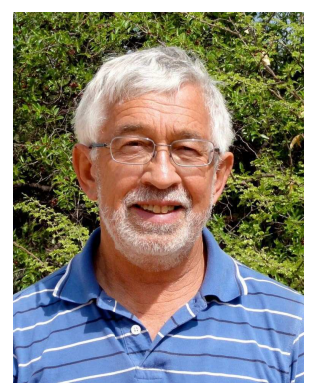

Nicolas J. Beukes is the Research Professor of Geology and Director of the DST-NRF Centre of Excellence for Integrated Mineral and Energy Resource Analysis (CIMERA) at the University of Johannesburg. He is essentially a field geologist with a focus on basin analyses and depositional systems in the Palaeoproterozoic. He has gained international recognition for his research on Neoarchean carbonate platform deposits and the origin of Precambrian iron formations, BIF-hosted iron ore and sedimentary manganese ore deposits. He is rated an A1 scientist by the South African National Research Foundation, received the Jubilee Medal and Draper Award of the Geological Society of South Africa and is an Honorary Fellow of the Geological Society of America.

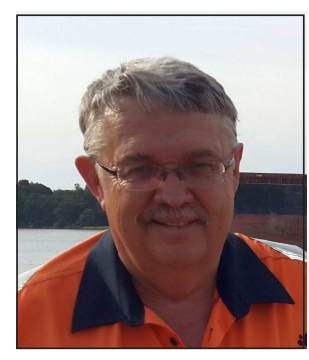

Ed Swindell Pr.Sci.Nat, FGSSA, MSc (Exploration Geology), BSc (Hons), B.Com, is an independent Consulting Geologist based in South Africa. During 38 years service with BHP Billiton he was involved in Base Metal and Uranium exploration, Geological Research and Target Generation, searching for primarily Witwatersrand Type Gold and from 1990 to 1999 he looked after the geological function on all Samancor's Manganese, Chrome and Industrial Mineral Operations. From 1999 to 2013 he held the position of Mineral Resources Manager - Manganese. He was involved in Manganese mining operations and exploration programmes in South Africa, Australia and Gabon.

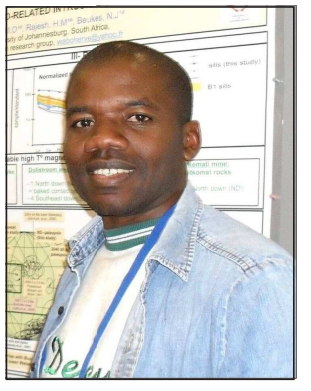

Herve Wabo is a Research Specialist based at the Palaeomagnetic Laboratory in the Department of Geology of the University of Johannesburg in South Africa. He holds a PhD from the University of Johannesburg (2009-2013) and was also a post-doc with NRF Research Grant at the same institution (2014-2015). His main research interest focuses on the characterization of the ancient geomagnetic field recorded by various Precambrian sedimentary (e.g. Barberton Banded Iron Formations) and igneous units (e.g. Bushveld marginal sills, Uitkomst Complex, mafic dyke swarms), and the use of this information to constrain the position of the Kaapvaal Craton within ancient supercontinents, with implications for palaeo-environmental reconstitutions and mineral deposit targeting. 